DEPARTMENT OF THE INTERIOR-U. S. GEOLOGICAL SURVEY

J. W. POWFLL DIRECTOR

TH E

\title{
PHYSICAL GEOLOGY
}

\author{
OF THE \\ GRAND CA NON DISTRIC'T
}

BY

CI.ARTNCE E. D้UTTON

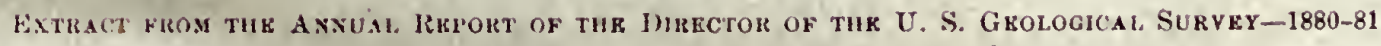

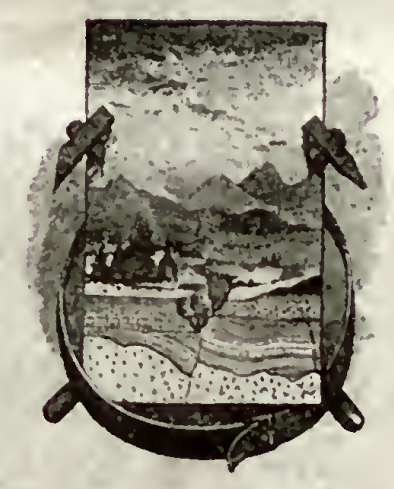

53081

WASHINGTON

GOVERNAENT PIINTING OFTICE

1882 
T $\mathrm{HI}$

\section{PHYSICAL GEOLOGY OF TIL}

GRAND CAÑON DISTRICT.

B Y

53081

CAPT. OLARENCE E. DUTTON, ORDNANCE CORPS, U. S. A. 


\title{
THE PHYSICAL GEOLOGY OF THE GRAND CAÑON DISTRICT.
}

\author{
By Clarence E. Duttos.
}

\section{CHA P TER I.}

\section{THE PLA'TEAU PIOVINCE.}

The investigations made by this division of the Geological Survey during the last two years have been pursued with the object of increasing our knowledge of the plyssical and historieal geology of the West and have had little relation to economie interests. The field of labor is one of the most impressive and instruetive in the world-impressive by reason of the magnificent seale on which certain processes of natmre have operated, and instrnctive beeanse the eauses, methods, and results of those processes are revealed with a distinetness which is mparalleled. 'This field comprises the Grand and Marble Cañons of the Colorado and the regions which drain into them. 'Io the entire tract, comprising an area of more than 13,000 square miles, I have given the name of the GRAND CAÑON DISTRIC'T.

The lessons which the geologist finds in this district are many, but the most conspieuons one embraees those smbjeets which are inchurled under' the nearly synonymous names "LAND ScUlp'TURE," "IDENUDATION," "Erosion." These processes operate mpon the land uneeasingly, carring out mountains and valleys and giving shape and character to the earth's surface. They represent the work done upon the land by the winds and rains, by flowing water, by the ehemieal reactions of the at. mosphere and of organic life. These proeesses are operative ahmost everywhere, and their results in the lapse of immense periods of time attain unagnitudes, the statement of which may astonish the ordinary reader and perhaps exeite his incredulity, but which at length appear veritable when tested by geological researeh and deduction. In no other portion of the world are the natural laws governing the processes of land scnlpture exemplified so grandly; nowhere else are their results set forth so clearly. The interest excited by the grandeur of the subjeets is intensified, and the value of the lessons enhanced, by the exceptionally intelligible manner in which thein materials are presenter for study. 
For convenience of geological discmssion Professor Powell has divided that belt of conntry which lies between the neridin of Denver, Colo., and the Pacific and between the 34 th and 43 l parallels into povinees, each of which possesses topographical featmes which distingnish it from the others. The eastermmost he has named the Park Province. It is situated in the central and western parts of Colorado and extends nonth of that state into Wyoming and sonth of it into New Mexico. It is pre. eminently a monntain region, laving several long langes of the second order of magnitude. The structure and forms of these momntains are not exactly similar to those of any other region now well known, bnt possess sone resemblance to the Alps, thongh not at very close one.

As we pass westward of these ranges in Coloralo we enter, near the western boundary of that state, a region having a very difrerent topography. The mountains disappear almost wholly, and in their stead we find platforms and terraces nearly or quite horizontal on their smm. mits or floors and abruptly terminated by long lines of cliffis. 'They lie at greatly varying altitudes, some as high as 11,000 feet above the sea, others no higher than 5,000 , and with still others ocenpying intermediate levels. Seldom does the surface of the laud rise into conical pealis or into long narrow erested ridges; but the profiles are long, horizontan lines sudderily dropping down many hundreds or even two thousind feet upon another flat plain below. This region has been very appropriately named, by Powell, the Platean Province. It ocenpies a nanow strip in the extreme western part of Colorado, a similar strip of western New Nexico, a large part of sonthern Wyoming, and rather more than half of Utall and Arizona.

West of the Platean Province is the Great Basin, so named by Fremont because it has no dranage to the ocean. Its topography is wholly peculiar and bears no resemblanee to either of the two just allnded to. It contains a large number of ranges, all of which are very nar'ow and short, and separated from each other by wisle intervals of' smooth, barren plains. The mountains are of a low order of magnitude for the most part, thongh some of the ranges and peals attain considerable dinensions. Their appearance is strikingly different from the noble and picturesque ontlines displayed in Colorado. 'They are jagged, will, and ungracefin in their aspect, and, whether viewed from far or near,
repel rather than invite the inagination.

The Wasatch, howerer, is an exception. This noble lange is properly a part of the Basin Province, and is one of the finest and most pictur. esque of the West, but so completely does it contrast with the other Basin ranges that it may be regarded as an anonaly annong them. The topographical features of this regrion are also fonnd ontside of the linits whieh Frémont assigned to the Great Basin, and reach southwand into Arizona and uorthward in to Idaho and Oregon. The Basin proper covers the western part of Utal, nearly the whole of Nevada, and a small portion of southern Oregon and Idaho. Its western bonndary is
the base of the Sierra Nevalit. 
No attempt will be made here to charaeterize the Sierra Nevada, partly beeanse it is not thoroughly understood, but especially because it is remote from the region here to be discussed, and presents few considerations essential to that diseussion. The Graud Cañon District is a part of the Plateau Provinee, and to this provinee as a whole we mar now levote our attention.

As already indicated, it lies between the Park and Basin Provinces, and its topoglaphy differs in the extreme from those foumd on either side of it. It is the land of tables and terrices, of buttes and mesas, of cliffis and eañons. Standing upon auy elevated spot where the radius of vision reaches ont fifty or a hundred miles, the observer beholds a strange speetacle. The most eonspienons objects are the lofty and brilliantly colored

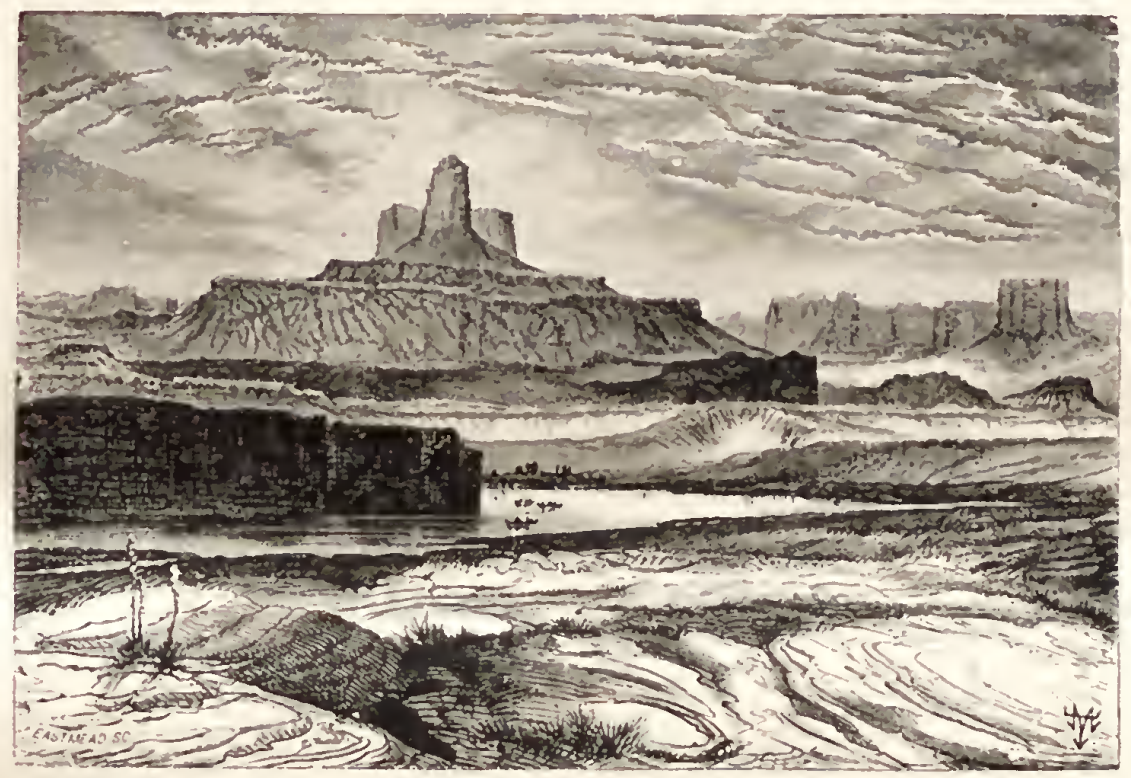

Fir. 2.-Butte of the Cross. Trias.

cliff's. They streteh their tortuous courses across the land in all direetions, ret not without system; here throwing ont a great promontory, there receding in a deep bay, and contimning on and on until they sink below the horizon or swing behind some loftier mass or fade ont in the distant haze. Each chifl marks the boundary of a geographical terrace and marks also the termination of some geological series of strata, the edges of which are exposed like eourses of masonry in the sedrp-walls of the palisades. In the distance may be seen the speetacle of elift' rising above and beyond cliff, like a colossal stairway leading from the torrid plains helow to the domain of the elouds above. Very wonderful at times is the seulpture of these majestic walls. 'There is an arehitectural style about it which must be seen to be appreciated. The resemblauces to architecture are not fanciful or metaphorical, but are real and vivid; so mueh so that the macenstomed tomist often feels a vane sliepticism whether these are truly the rorks of the blind forces of uature or of some nutelligence akin to the human, but far mightier; and even 


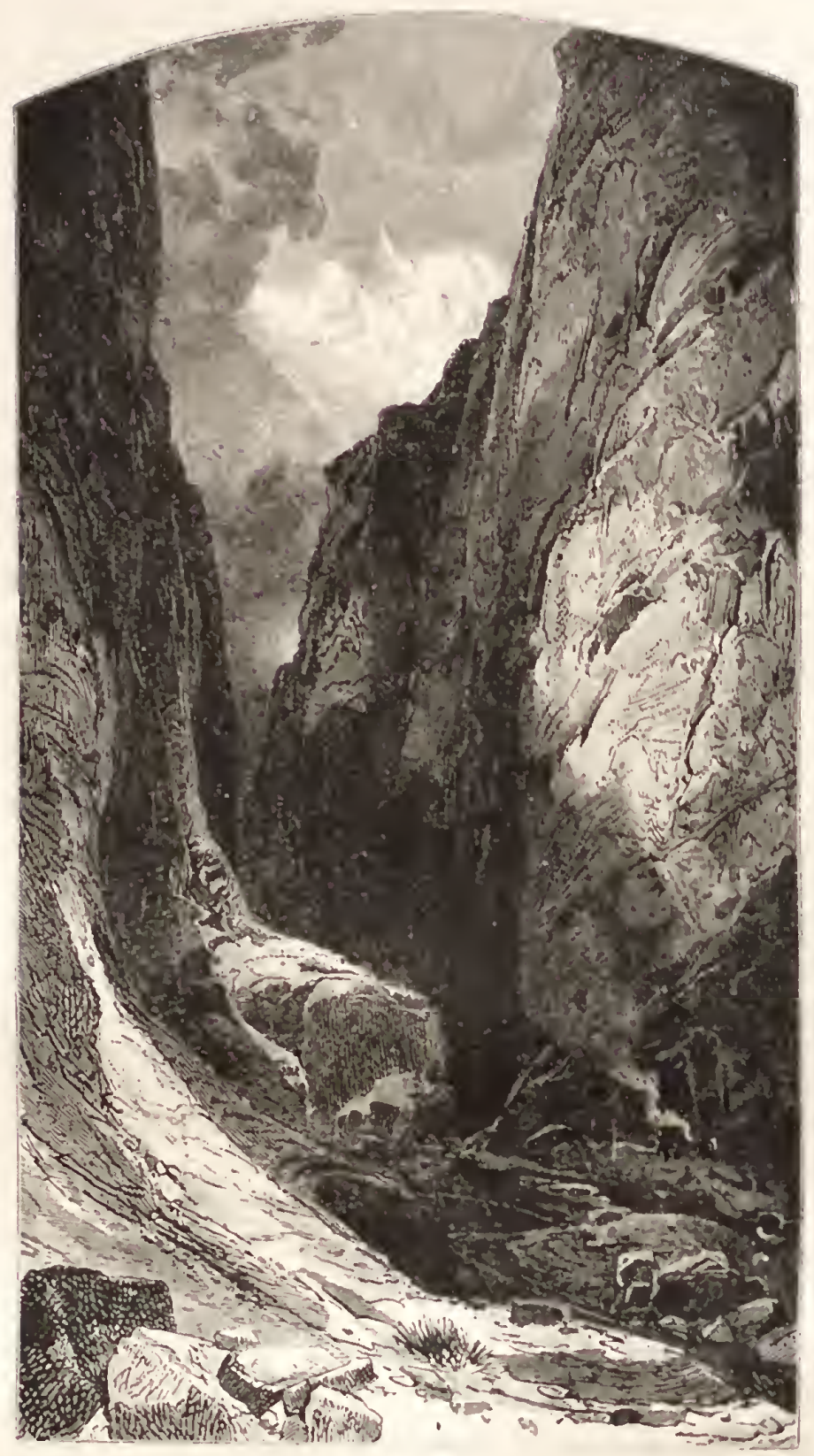

FI(: 3.-A lateral enñon. Escalante.

the experieneed explorer is sometimes brought to a sudden halt and filled with amatement by the appation of forms as definite and rob. quent as those of art. Each geological formation exhibits in its cliffs a distinct style of architecture which is not reprodured among the difls of other formations, and these several styles differ as much as those which are cultirated by different races of men.

The charaeter which appeals most strongly to the eye is the coloring. The gentle tints of an eastern lanilseape, the pale blue of distant mommains, the green of remal or summer vegetation, the subdued colors of hillside and meadow, are wholly wanting here, and in their place we behold belts of brilliant red, rellow, and white, which are intensified rather than alleviated by altornating belts of graly. Like the arehitect- 


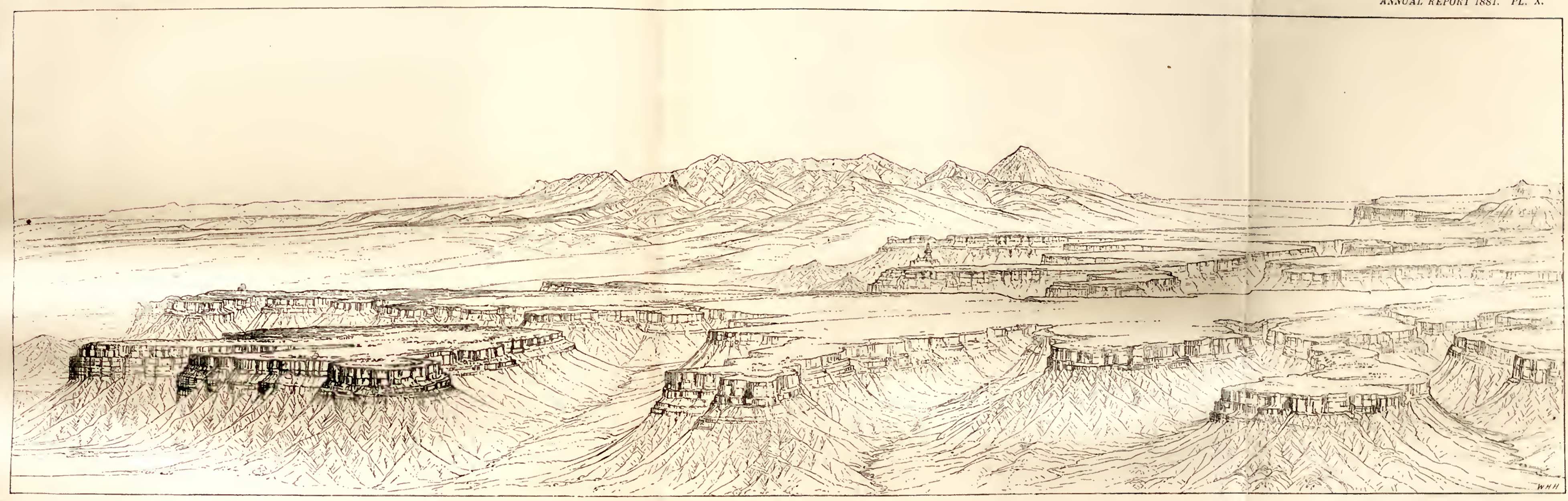

PIATEAU SCENERY -THE MESA VERDE-CRETACEOUS

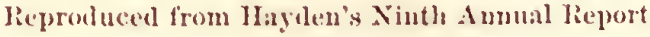


ure, the colors are characteristic of the geological formations, each series having its own group and range of colors. 'They culminate in intensity in the Permian and Lower 'Trias, where dark, brownish reds alternate with bands of chocolate, purple, and lavender, so (leep, rich, and resplendent that a painter would need to be a bold man to renture to portray them as they are.

The Plateau country is also the land of cañons, in the strictest meaning of that term. Gorges, ravines, canalas are found and are nore or less impressive in every high region; and in the vernacular of the WVest all such features are termed cañons, indiscriminately. But those long, narrow, profound trenches in the rocks, with inaccessible walls, to which the early Spaniards gave the name of cajon or cañon, are seldom found outside the plateaus. There they are inmmerable and the ahmost nniversal form of drainage ehamnels. Turge areas of the Platean cour. try are so minutely dissected by them that they are almost inaceessible, and some linited though considerable tracts seem wholly so. Almost everywhere the drainage chanmels are cut from 500 to 3,000 feet below the general platform of the immediate conntry. 'They are abmulantly ramified and every branch is a cañon. The explorer upon the mesas above must talie heel to his course in such a place, for once caught in the labyrinth of interlacing side gorges, he must possess rare craft and self-control to extricate himself. All these drainage chammels lead lown to one great trunk channel cleft through the heart of the Platean Province for eight huncled miles-the chasm of the Colorado, and the cañons of its principar fork, the Green River. By tar the greater part of these tributaries are dry during most of the year, and carry water only at the melting of the snow and during the brief periods of antumnal and vernal rains. A very few hold small, perennial streams, coming from the highlinds around the borders of the province, and swelling to mad torrents in times of spasmodic floods.

The region is for the most part a desert of the barrenest lind. At levels below 7,000 feet the heat is intense and the air is dry in the extreme. The vegetation is very scanty, and even the ubiquitous sage (Artemisia tridentata) is sparse and stunted. Here and there the cedar (Juniperus occidentalis)* is seen, the hardiest of arborescent plants, but it is dwirfed and sickly and seeks the shadiest nooks. At higher levels the regetation becomes more abmulant and varied. Above 8,000 feet the pliteaus are forest-clad and the ground is carpeted with rank grass and an exuberant growth of beautiful summer flowers. The summers there are cool and moist; the winters severe and attended with heary sllow-fall.

\footnotetext{
* Botanists inform mo that tho predominant upland juniper of tho Plateau Provinee, as the species aro now distributed aecording to Dr. Engelmann's revision published in 18ir, would bo Juniperus Californica, var. Utahensis, rather than J. occidentalis, somo of tho varieties of which may, however, occur there. Until that revision was mado the western junipers were littlo known, and several distinet species were indiseriminately elassed as J. occidentalis.
} 


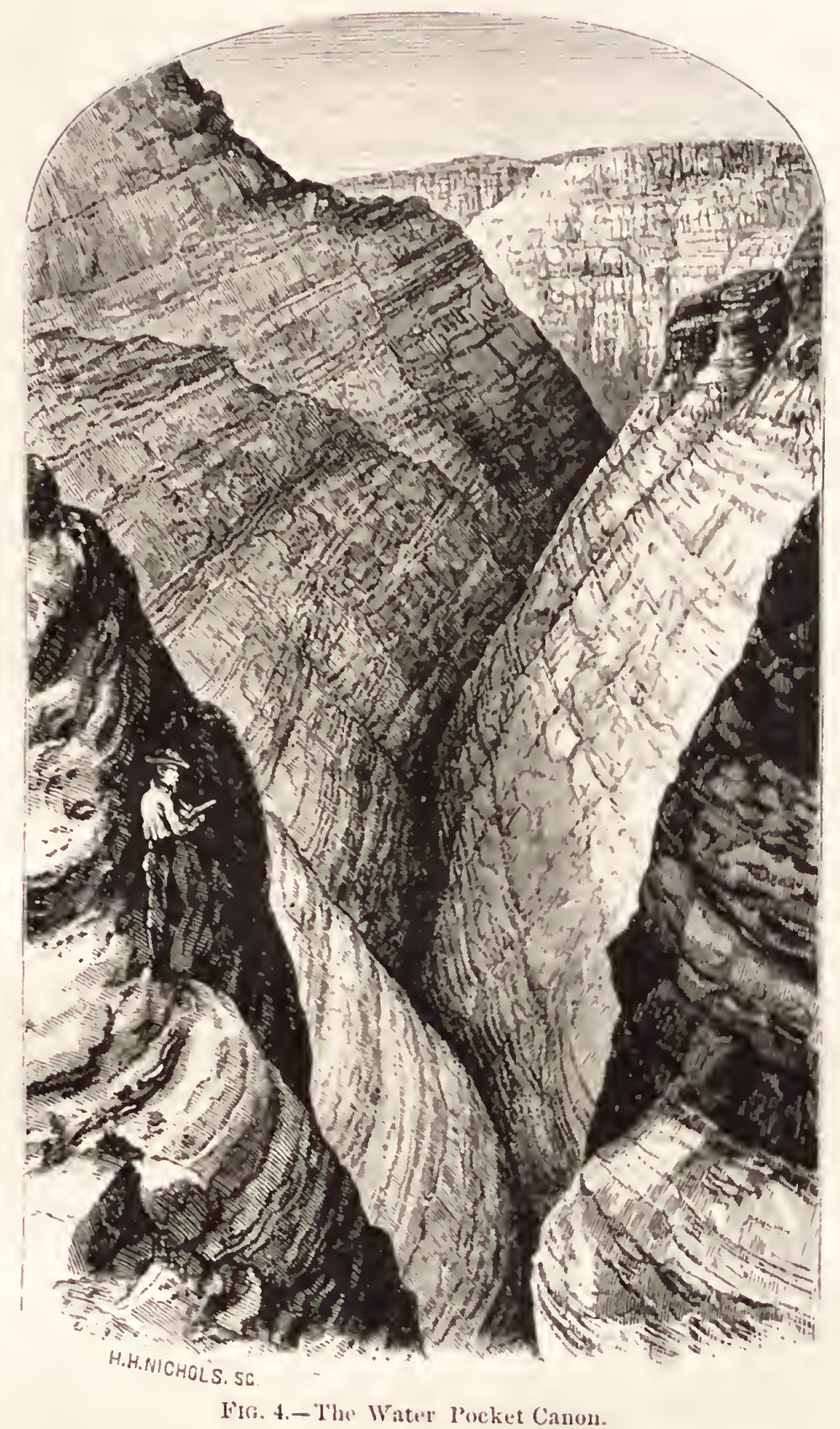

The Plateau Province is naturally divided into two portions, a northern and a sonthern. The dividing barrier is the Cinta range. This fue mountain platform is, in one respect, an anomaly among the western ranges. It is the only important one which trends east and west. Starting from the eastern flank of the Wasatch, the Uintas project castwand more than 150 miles, and nearly join perpendicularly the Park ranges of Colorado. Of the two portions into which the Platean Province is thus divided, the souther'n is much the larger. Both have in conmon the plateau features; their topographies, climates, and plysical featmes in general, are of sinilar types, and their geological featmes and history alpear to be closely related. Bnt each has also its peculiarities. The northern portion is an interesting and already celebrated field for the 
study of the Cretaceous strata and the Tertiary lacnstrine beds. 'The subjects which it presents to the geologist are most notably those which are embraced under the department of stratigraphy-the study of the succession of strata and co-related succession of organie life. Otherwise the region is tame, monotonons, and unattractive. The sonthern portion, while presenting an abundance of material for stratigraphical study, and in this respect fully rivaling, and perhaps surpassing, the northern portion, also abounds in the grandest and most faseinating themes for the student of physical geology. In respect to scenery, the northern portion is almost trivial, while the sonthern is the sublimest on the continent. With the former we shall have little to do ; it is the latter which claims here our exelusive attention.

The southern part of the Plateau Province may be regarded as a vast basin everywhere bonnded by highlands, except at the southwest, where it opens wide and passes suddenly into a region having all the chameteristies of the Great Basin of Nevada. The northem half of its eastern rim consists of the Park ranges of Colorado. Its northern rim lies upon the slopes of the Uintas. At the point where the Uintas join the Wasatch, the bomdary turns sharply to the south, and for 200 miles the High Plateans of Utah constitute the elevated western margin of the Province.

It is from the summits of the High Plateaus that we gain our first comprehensive view of those grand facts which are the principal subjeets of this discourse. But let me first ask the reader to endearor to f'rame some conception, however erude, of three lines, each 200 miles long, placed in the positions of three sides of a square; the fourth side being for the moment neglected. Upon the eastern side conceive the Park ranges of Colorado; mpon the northern, the Uintas; and upon the western side the southern portion of the Wasatch and the High Plateans of Utah; and all these highlands having altitudes ranging from 9,000 to 12,000 feet above the sea, while the included area varies from 5,000 to 7,000 feet high. The space thus partially bounded may represent the northern part of the sonthern Plateau Province. Along the line re. quired for the fourth and south side of the complete square there is no bomndary. The topography contimes on beyond it to the sonthward, and also widens out both west and east and overspreads an additional area more than twice as great as that already defined. From the eastern erests of the High Plateaus we may obtain an instrmetive orerlook of the northern portion of the sonthern Platean conntry.

'The easiest line of approach is from Salt Lake City. Proceeding south from that town along the western base of the Wasatch, we reach the sonthern end of that fine range about 90 miles from Salt Lake. The last monntain pile is Mount Nebo, and skirting aronnd its sonthern flank we soon perceive to the southeastward a long and very lofty ridge 20 to 30 miles distant. 'This is the Wasatch Plateau, the northermmost member of the group of High Plateaus. It has nothing in common with the 
Wasateh Momntain range, being wholly diseomected from it, and standing with a wide interval en échelon to the southeastward of it. 'The Wa. satch Platean presents a long, straight, horizontal smmmit projected anainst the sky withont peaks or domes, resembling somewhat the ridges of Pemsylrania and Virginia, but on a grander scale. We pereeive along its entire western front a rapid slope, deseending to the bottom of the San Pete Valley at its foot. It is not deeply incised with ravines and amphitheaters, nor notehed with profomd transverso gorges, as aro ordinary mountain ranges, but shows a slightly diversified slope in every part. As we draw nearer we begin to see the attitudes of tho strata composing its mass, or, as the geologists say, its "structure." The strata are inclined at the same augle as the slope of its flank. In the valley below, the beds are horizontal ; as they approaeh the base of the platean they flex npwards and ascend the slope; as they reach the summit they flex back to horizontality. If we ascend the platean and ride eastward a very few miles, there suddenly breaks npon the view a vast and inpressire panorama. From an altitnde of more than 11,000 feet the eye can sweep a semieircle with a radins of more than 70 miles, and reach far ont into the heart of the Platean comntry. We stand npon strata of Lower Tertiary age, and beneath our feet is a precipice leaping down across the level edges ofthe beds npon a terrace 1,200 feet below. The eliff' on wheh we stand stretehes far north ward into the hazy distance, gradually swing. ing eastward and then sonthward throngh aconrse of more than a hundred miles, and vanishing below the horizon. It describes, as we well know, a rude senieircle, around a center abont 40 miles cast of our stamd point. At the foot of this clift is a terrace of greatly varying width, rarely less than 5 miles, eonsisting of Upler Cretaceous beds nearly but not quite horizontal. They incline upwards towards the east at angles rarely so great as $3 \circ$, and are soon cint off by a seeond cliff plnnging down 1,800 feet upon Middle Cretaeeous beds. This reeond cliff describes a semieirele like the first, bnt smaller and coneentrie with it. From its foot the strata still rise gently towards the east, through a distance of about 10 miles, and are cut ofr' as before by a third series of eliff's concentrie with the first and seeond. For the fourth and fifth time this process is re. peated. In the center of these girdling walls is an elliptical area abont 40 miles long and 12 to 20 miles broad, eompletely surrounded by mural esearpments more than a thousand feet high. This central spot is ealled the SAN RAFAEL SWELL, and it is full of interest and suggestion to the geologist. From its central point the strata dip away in all directions, the inclinations, however, being always very small.* This configuration of the strata (dipping away from a eentral point in all direetions) is technically termed "quaquaversal."

The accompanying diagram (Plate XI) shows the relative masses and positions of the strata as they would appear in vertical seetious cutting

"Upon the eastern margin of the swell is one of those great "monoclinal flexures" with a high inclination so characteristic of the Plateau Country. These will be ad-
vertel to hereafter. 


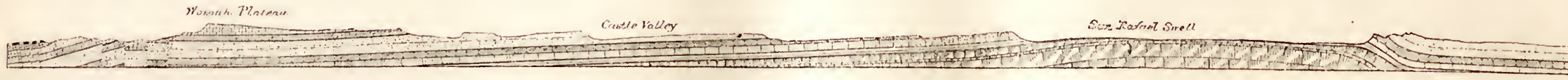

Mrearobih Placeon

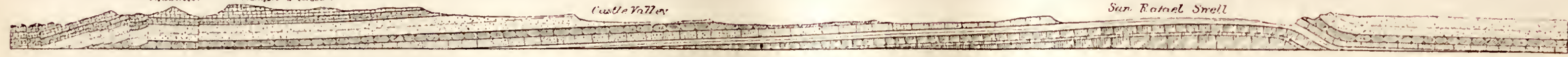

Siun. Rarmet Sirell

Sections from San Pete and Sevier Valleys across the Wasatch Monoclinal to the San Rafael Swell. 
east and west through the Wasateh Plateau to the San Rafael Swell. It will be observed that the lower 'Iertiary is found only on the summit and westeru flank of the plateau. 'The Cretaeeous extends further out, but is at last cut off in turn; and as lower and lower beds are exposed to daylight, they too are similarly cut off until the summit of the Carboniferous is nearly or quite exposed within the swell itself. 'The approximate length of the seetion here given is about $5 \tilde{5}$ miles, and the thiekness of the strata from the summit of the Carboniferous to the top of the Lower Tertiary is nearly 11,000 feet.

The geologist who becomes aware through observation of the general facts thus set forth quiekly reaches the following eonelusion: The beds which are sucessively terminated in the terrace eliffs once reached further eastward, and in all probability every one of them extended in full volume and without a breali entirely over the locus of the swell to regions far beyond it. Upon the eastern side of the swell, and at varying distanees from it, the missing strata reappear in inverse order, with terminal eliffis faeing the westward. From the intervening spaee they liave been swept away by erosion.

In restricted localities of a few square miles, in a river valley, in the open glades of a hill-eountry, the most unscientific observer may be easily convinced that the waste of thousands of years has broken the continuity of the strata and quarried away large masses of roek. But in the wide expanse before us even the mind of the geologist may falter before accepting a conclusion so portentnus. The magniturle of the work is oppressive, and cautious philosopliers are reluetant to take np and earry the burden of unusually large figures. 'They prefer to cast ahoutin order to see whether some easier eonclusion may not be discovered. The one already stated is to the effect that a body of strata more thin 10,000 feet thick and more than 500 square miles in area lave been swept off from the surface of the swell; that nearly 9,000 feet lave been removed from a. much larger annular space around it; 7,000 feet from a still larger and remoter space; and so on with expanding amuli, from whieh successively decreasing amounts liave been denuded. It is needless to define iust here the linits of the denuded region, even if it were possible. It is sufficient to say that its extent is much more than 10,000 square miles, and that the thieliness of the strata removed varies from a few hundreds to 111 ore than 10,000 feet. Nor does the conclusion stop here. The San Rafacl region is only one of a considerable number of the subdivisions of the Plateau Province where the same enormous extent of erosion has tiken plaee. It is not the largest of those subdivisions, nor is the thiekness of the renoved strata the greatest there. It is merely an example, and whatsoever it reveals in regard to erosion is but a group of erents conmon to the entire sonthern provinee with its vast area of nearly 100,000 square iniles. I have seleeted it for discussion beeause its array of facts in evidence is more easily handled and can be more hucidy presented than those of the other subdivisions. Let us, then, examine in 
detail the arguments upon which this dechetion of a great denndation is based.

If we stand before one of the great malginal clifis which bomnd the several terraees, we shall speedily deteet abundant evidence that tine and the elements are slowly robbing its face of the materials which com. pose its mass. Fragments liave spawled off and fillen, and they now lie at its base in great quantities, forming a talns. Cliff and talns alike are seamed and scored with rain-gullies, and if we are fortunate enough to observe the effeets of a shower we shall see the waters trickling, spont. ing, or lushing down through every seam and gully, carrying sand, mul, and small fragments with which they are charged to their utmost calpacity. The meaning of this is that the eliti is wasting away, and its locus through the ages is farther and farther back. 'This backward movenent of the line of frontage by slow waste is very happily named by Powell the Recession of Cliffs.

It may seem at first as if the rate of recession must be so exceedingry slow that when we are asked to consider the possibility of a recession of thirty or forty miles the argument would break down under the weight of its time-factor. But it will be shown hereafter that in the total pro. eess of denudation the rate of recession is rapid enough to satisfy the temper of such geologists as nay be parsimonious ol even very stingy in their allowances of time. It is snfficient here to advert to the very obrions fact that the eliffs are receding, and that at some former greo. logical period they once stood nearer the center of the denuded district. Now, it is suffieiently obvious that if we aliow the imagrination to range. back indefinitely into the past and reverse the process of recession, re. storing the material which has been denuded, the continuity of argmuent will at length bring us to an epoch in which the elift's whieln now fice the center of the San Rafiel Swell cane tugether, and the strata which tlose cliffs now terminate streteher unbroken from west to east across the whole width of the Plateau Province. It is only a question of time and contimuity of the proeess. The geologist may, however, raise a very pertinent inquiry. Admitting that the eliff-bonnd strata onee reached out in advance of their present limits, may they not have grown thiner as they approached the center; may they not have attennated rapidly so that their formel thickness over the swell was but a small fiaction of the agrregate thickness disclosed in the present escarpments? May not the higher beds love thinned ont and disappeared entirely a few miles from their present boundaries? In all other well-studied regions it is a generil and ahmost universal rule that the strata vary greatly in thickness when traced from place to place, and attenuate as they extend away from their shore-lines. May they not have done so here?

Answering the questions directly, it may be said that the Peru,iun, Trias, and Cretaceous eertainly did not grow perceptibly thinner as they approached the eenter of demudation. The Jurassic did thin ont quite notably from west to east, and it is possible that the Tertiary may have 
thinned a little; but this loss of thickness in the Jurassic and Tertiary has been abundantly discounted in the estimate given of the mass of strata denuded. As regards the general rule that strata vary greatly in thickness, it may be stated that the Platean country is a remarkable exception to it. One of the most striking features in its stratigraphy is the wonderful persistency with which its formations maintain their vol. umes and lithological features over great areas. In this respect the province has no parallel, not even in the caln and undisturbed terrains of the Mississippi Valley.

Further support of this conchnsion may be fonnd by reverting to the section (Plate XI). On the eastern side of the swell the section shows a great monoclinal flexure where the strata extending eastward rapidy bend downward and subsequently flex back to horizontality. Before this flexure began to form, the Cretaceous strata had already been deposited. Possibly, also, the Tertiary had been laid down, but of this we are not as yet certain. But we know that it was formed after the Cretaceous age, for the strata abundantly betray it. If we conld bend back the strata now inclined up ward in that flexure, we should have a wall ahont 8,000 feet high or more, looking down from the east mpon the centrul amphitheater, and in that wall would appear the broken edges of the Permian and Mesozoic beds, though the npper part of the Cretaceons and Tertiary wonld be wanting at the summit. Thus nearly four-fifths of the dennded strata appear npon the eastern side of the swell, in very close proximity to it, and the remainder make their appearance at vary$i_{11 g}$ distances beyond. There is no appreciable loss of volume in the exposed beds of the monoeline as compared with the corresponding beds to the westward.

But we may with advantage pursue the task of restoring the beds to the position they held during the period of their deposition by straightening ont or bending lack the strata in those parts where they have been tilted and flexed since their accumnlation. This is readily done here. They were deposited originally in layers which were quite horizontal. We know this by reasoning upon the following facts. From the summit of the Permian, and I think we may say quite confidently from the summit of the Carboniferons upwards, the whole series was deposited in very shallow waters. The evidence of this is overwheln. ing. We find proof that the surfaces of deposition thronghont Mesosoic time oscillated repeatedly a little below and a little above sea-level. The cross-bedded sandstones of the Trias and Jur:i, the sandy shales wonderfully ripple-marked, the occurrence of bands containing the silicicified remains of forest trees, the occasional recurrence of contacts showing "unconformity by erosion" witlont any nnconformity of dip,," the occurrence of brackish-water types of mollnsea in the Jurassic, tho

* There are throughout the series numerous instanees of beds resting upon surfaees slightly eroded and channeled by streams withont any diserepancy of dip in the apposed beds. 
lignites, fossil leares, and carbonaeeons shales of the whole Cretaceous system, the brackish-water fossils of the lowest l'ertiary, leave no doubt as to the verity of the foregoing inference. 'The final restoration, then, of the strata to their original positions leaves them horizontal.*

If we draw a section of the strata restored to horizontality, we shall find that the strata now remaining require, in order to perfect their eontimuity, the restitntion of large masses fully equal to those which we have inferred to have been swept away by erosion. Any hesitation to do this would leave us without resource. Any other hypothesis, so far as I ean conceive, would be not only withont support in the facts presented, but in opposition to their entire tenor and purport.

The geologist who is familiar throngh long field-study with the phys. ical problems presented in the West wonld not need further argmment to become satisfied of the reality of the great erosion here inferred. Perhaps he would consider that too much has been said in support of it aheady; espeeially sinee the subject of this paper is not tho San Rafael bnt the Grand Cañon district. But I have deroted so mueh dis. cussion to the San Rafuel district beeause it is a type of a concreries of districts which make up the Platean Province, and becanse it exemplifies in the most intelligible, compact, and complete mamer the broarl facts and laws which are to engage onr attention hereafter. 'Lhese facts and laws apply to the Grand Cañon district; but to take the fucts there presented and arrange them in a clear view before the mind of one who has never visited that region, and make them definite and convineing, would be extremely difficult without preparatory exercises on problems similar in lind but simpler in form. For this reason I propose, before leaving the San Rafael district, to bring out another eategrory of facts which it exemplifies. They involve a generalization very interesting in itself, and of the greatest utility in solving many problems presented in all parts of the Platean country. 'This generalization-or law in the sense of an observed order of facts-may be called the P'ersistence of Rivers.

The rivers of the Atlantic Stites, from the Hudson southward, cut through the Appaliehian ridges by narrow gorges, or gaps, which seem to have been quarried out for the purpoes. Geology, however, does not

* It would bo very instruetive, if space permitted, to elaborate this discussion of the original horizontality, and I am tempted to point out in tho hastiest manner some obvious eonsequenees of the deduction. It appears that if this deduction be true the deposits must have settled or subsided as rapidly (in the long run) as they were accuruulated. The surface of deposition appears never to have varied unch from sealevel. But the total aecumulation of Permian, Mesozoic, and Tertiary beds was nearly 11,000 feet, and when the deposition ended (supposing that it ended in tho Midale Eocene, though I think it more probably continued lere until the elose of the Eocene) the Permiau must have sunken more than two miles below sea-level. The gradual sub. sidence of large bodies of sediment as they aceunulate in strata is a fact now generally recognized, and is of universal application. That it is eaused by tho gross weight of the enormous masses of deposited material sinking into the yieldiug earth scems : most natural explanatiou. 
take account of "purposes" or "design," but seeks its explanations in "natural" causes alone. It asks by what natural processes were those gorges made?

The answer it funds is, that the rivers themselves scoured them ont, and that secular decay has widened them somewhat. A reader not versed in geolngy might be led to ask a further question. Inow can a river attack a mountain wall, or even a gentle declivity, and quarry thongh it a pathway giving a continuons descent for the flow of its waters? The reply is that no river ever loes that. 'Lo mulerstand how it all came about we must go back to the begimning. The rivers were born with the comntry itself. The land emerged from the sea; and when it emerged the rains or melting snow sought whatever channels were determined by the slight inequalities of the newly-risen surface and flowed seawarls. These lofty ridges, gashed with noble ravines, had then no existence. The rivers are older than the mountains. As time ran on the monntains grew npwarl, athwart the conrses of the streams. But a flowing river has a power to fight for and maintain its right of way, which becomes apparent only when we have carefully studied and analyzed it. This power is inherent in the descent of its waters-is literal water-power. The weapons or tools are the sand, gravel, and silt which the waters carry, and which act after the manner of a sand-blast, except that in the sand-blast the grit is impelled by air or steam, while in the river it is impelled by water. This power, inherent in the fill, increases rapidly as the fall increases. When the declivity is feeble the power to grind down the channel-to "corrade" as Pow ell terms it-is correspondingly feeble, or even amihilated. When a barrier like a ridge rises across the track of a stream the leclivity is increased at that point. Increased relocity and corrasivo power is at once developed in the stream, and it cuts down the barrier. Perhaps a lake may be formed above the barrier, bnt its outlet will be cut down and the lalie drained.

In a low conntry the slopes are, with rare exceptions, feeble, and this corrasive power by which the stream maintains its locus is in such comn. tries correspondingly fechle. Here we may expect to find many cases where streams have been deflected largely from their courses; but in a higl country the reverse is the case. In a region newly risen from the waters the positions of the streams may be very inconstant; but as the elevation increases they gradnally fasten their grip mpon the laud and hold it.

It would be difficnlt to point out an instance where a great river has ever existed under conditions more favorable to stability of position than those of the Colorado and its tributaries. Since the epoch when it began to flow it has been situated in a rising area. Its springs and rills have been among high monntains, and its slope since the earliest period of its history has always been great. 'The relations of its larger. tributaries have, in these respects, been the same; and indeed the river 

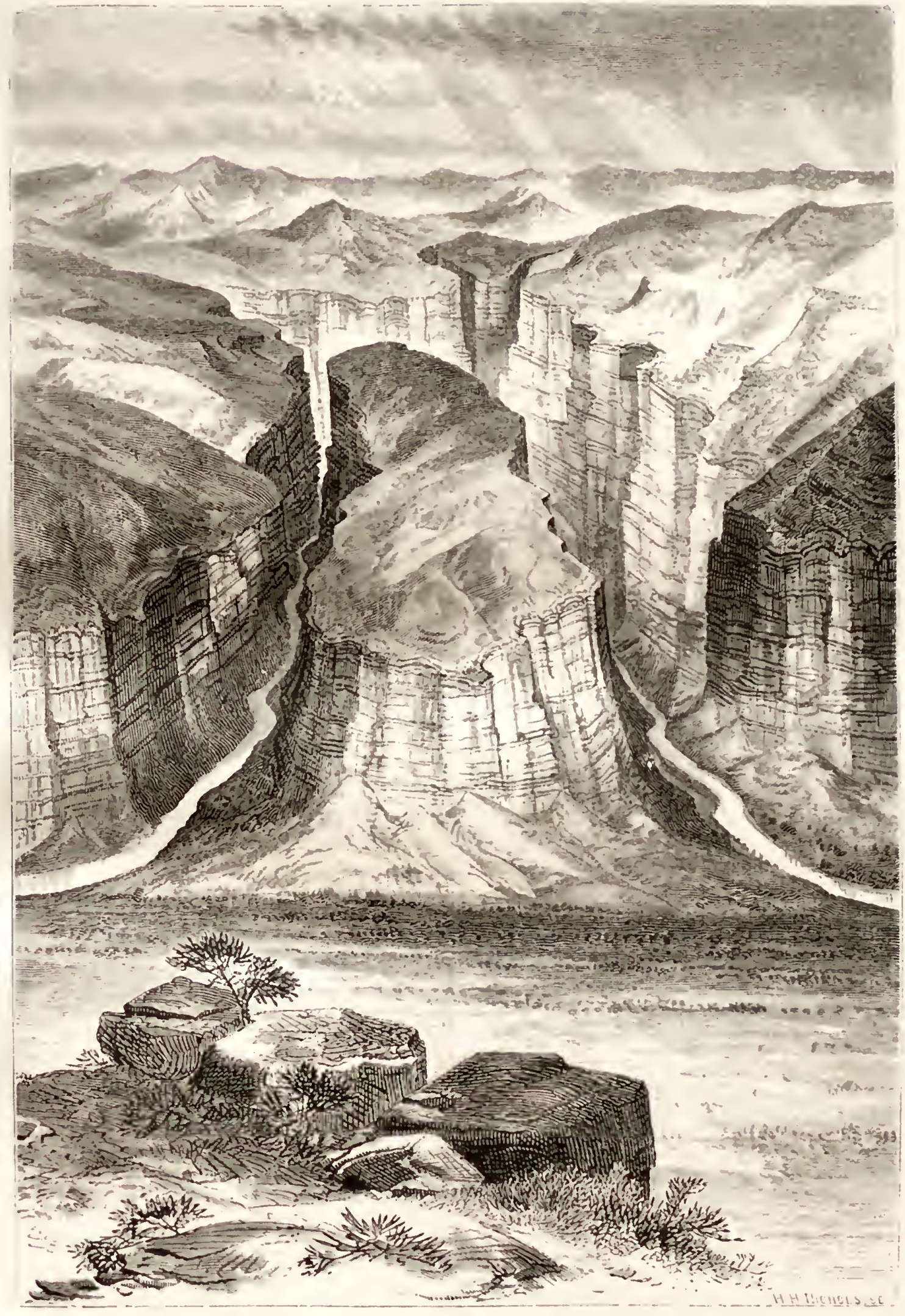

HORSESHOE CANON, GREEN RIVEK.

Erom Powell's Exploration of the Colotario Rirer. 
and its tributaries have been a system, and not a mere agrregate; for the latter are dependent mpon and responsive to the physical conditions of the former. Aurl now we come to the point. 'The Colorado and its tributaries run to-day just where they ran after the region emerged from the waters. Since that time momtains and plateaus have risen across theil tracks, whose present summits mark less than half their tolal amounts of uplift. 'The rivers have cleft them to their foundations.

The Green River, passing the Pacific Railway, enters tho Uinta platform by the Flaming Gorge, and after reaching the heart of the chain turns eastward parallel to its axis for 30 miles, and then southwarl, cutting its way out by the splendid cañon of Lodore. Then following the base of the range for a few miles a strauge caprice seizes it. Not satisfied with the terrible gash it has infleted "pon this noble chain, it darts at it viciously once more, and entering it, euts a horseshoe cañon in its flank 2,700 feet (leep, and emerges near the point of entrance; thenceforwarl, through a tortuous course of 300 miles, it flows southward through gently inclined terraces, which riso slowly as the river descends. Along this stretch it runs almost constantly against the dip of the beds, cutting through one after another, begiuniug with the Upper Eocene until its chamel is sunk deep in the Carboniferous. Further down, the Kaibab Plateau rose up to contest its passage, and a chasm 5,000 to 6,000 feet (leep is the result. It is needless to multiply instances; the whole province is a vast eategory of instances of river channels cutting through plateaus, mesas, and teraces where the stratadip up stream. The courses of the cañons are everywhere laid independently of the topographical inequalities, whether these inequalities be due to the broader features of land sculpture or to displacement and unequal uplifting. On the north and west side of the Colorado the tributaries generally run comter to the structural slopes; on the east and soutl sides, they ram more nearly with them.

It is clear then that the structural deformations of the surfice, the uplifts and downthrows had nothing to do with determining the present distribution of the platean drainage. The rivers are where they are, in spite of them. As irregularities rose up, the streams turned neither to the right nor to the left, but cut their way through in the sane old places. 'The process may be ilhstrated by a feeble analogy with the saw-mill. The river is the saw and the rising strata are the timber which is fed against it. The saw-log moves while the saw vibrates in its place. The river holds its place as rigidly, and the rising strata are dissevered by its ceaseless wear. What, then, did determine the situations of the present drainage channels? The answer is that they were determined by the configuration of the surface existing at, or very soon after, the epoch of emergence. Then, surely, the water-courses ran in conformity with the surface of the uppermost (Tertiary) stratum. Soon afterwards that surface began to be deformed by unequal displacement, but the rivers had fastened themselves to their places and havo ever since refused to be diverted. 
This theorem is of great ntility in the study of the Platean Province, for it throws light upon many problems which would otherwise be obscimre. The eourse of a river is the index of the slope, and, to a great extent, the configuration of the primitive mumodified surface of a traer. It betrays the amomt of tilting or flexing which the strata have undergone, and also conveys information as to the amomnt of strata whieh have been dennded. This information, however, is in many cases incomplete, but when plaeed in relation with other facts it frequently becomes conelusive. The application of the theorem to the San Rafael distriet is a beantiful instance of its validity.

Across the San Rafael Swell extend two river channels, one erossing it near the northern and the other near the sonthern end. They head in the High Plateaus, and pass throngh the snccessive terraces in deep cañons; then crossing the swell, enter the high cliffs on the eastern side and flow on. The northern strean-the Sim Rafael River-nltimately joins the Green River; the southern one-Cnrtis Creek-enters ihe Frémont River, a tributary of the Colorado. A glance at the map and an interpretation of the topography as expressed by the contonrs will quickly show that these streams are quite independent of the existing topography and eonld not have had their sitmations determined by it. They must hare been laid ont upon some ancient surface differing widely from the present. To find that surfaee is not difficult. It mnst have had a contimnons descent, thongh doubtless of slight declivity, from the western margin of the province to the line of the Green and Colorado Rivers. We shall obtain precisely that surface eonfiguration by redncing or bending back the flexures, and depressing the tilted strata until the Cretaeeous beds are everywhe horizontal, and then filling np the gaps made in the contimity of the strata by erosion. Thus we shall reach, by argument from the persistence of rivers, the same conclusion which we reached by studying the effeets of the reces. sion of cliffs, and by the independent study of the displacements.

The example of erosion thus given by the San Rafael Swell illustrates, as a sharply defined type, the denndation of the Plateau Province. The thickness of the strata removed varies greatly in different portions. In the Migh Plateans it has amounted to only a few hundred feet. In large areas it amounts to two or three thousand feet and in others of consid. erable extent it reaches more than 10,000 feet. Preliminary compari. sons of known facts derived from nearly the entire extent of the southern province lead to the conclusion that on the average 5, 500 to 6,000 feet of strata have been remored from its entire expanse. Our knowledge of the geology of some portions of it is at present very imperfect. Still, enough is known to justify us in beliering that this smmury estimate will not be mueh affected by future investigation.

We may for special purposes of eonvenience regard the province as consisting of districts or spots of maximm erosion separated from each other by high mesas or dividing platforms where erosion has been at its 
minimnm. The San Rafael district may be regarded as one of these areas of which the central part is an area of maximum erosion while its peripheral parts are areas of minimum erosion. 'The Grand Cañon dis. trict is another, and there are still others which we need not here specify.

Before eoncluding the introdnetory part of this paper it will be desirable to recite briefly the succession of geological events which the stury of the region has thus far brought to light, selecting ouly such as will hereafter be of special intility.

Throughout the great Carboniferousage the entire area of the Platean Province was submerged beneath the ocean. Deposition of strata went on continuonsly. The thicliness of the strata acemmulated in that age appears to hare varied greatly, and the deposits were laid down nnconformably over the surface of a country which had been ravaged by a great erosion. Such exposnres of the Carboniferons as now exist, how. erer, exhibit for the most part a remarkable evemess of stratification. In the interior spaces of the province the beds are either horizontal, or if disturbed, givo full evidence that the disturbances took place long after their deposition. The close of this age evidently left a subaqueous surface, which was exceedingly flat, and, except aronnd the borders of the province, quite free, so far as we now linow, from any apploceiable inequalities.

The thickness of the Carboniferous system is from 4,500 to i,,000 feet in the interior of the province, but around its borders, and in the Uinta Mountains, it is sometines fomd iu far greater volume. Its strata consist of impure limestones, occasionally of enormous thickmess in the individual beds, and altemating with fine-graned homogeneons samdstomes. Extensive leds of gypsum also occur.

After the Carboniferons came the Permian age, in which were laid down from 800 to 1,500 feet of sandy shales. The stratification was wonderfully even and everywere horizontal. The Permian beds are often ripple-ınarlied and betray inany evidences that thej accumblated in shallow waters. Among these evidences are the appearance at several horizons of indications that for a time the sea-bottom was laid bare by the recession of the waters, or by the eleration of the platform itself; for wo may discern evidences of slight erosion at the contacts of tho beds. But the horizontality of the beds appears never to have been notably distnrbed.

The same state of affairs continned throngh the Trias. There, too, wo find evidence of alternations of emergence and submergence in the shape of slight unconformities by erosion, and in the ocenrrence of extensive remains of silicified forests. The Triassic series is composed almost wholly of sandstones, the only calcareous matter being thin seams of gypsmn. The sandstone beds are very numerous and often shaly. They are usually of no great thickness individually, but there is one very notable nember of which we shall see moro when we come to view the Vermilion Cliffs. 
Directly upon the Trias rests the Jurassic. A wonderful bed of sandstone $\mathrm{S} 00$ to 1,200 feet thick, and very white and sugary in color repre. sents the principal part of this series. It is a very notable formation because of its remarkable homogeneity, the persistent way in whieh it preserves its lithological characters througl great distances, and the absence of divisional planes of stratification-the mass being solid from top to bottom. But most striking of all is its wonderful cross-bedding, far surpassing in beauty, extent, and systematic character, any similar phenomenon elsewhere, with which I am acquainted. The summit of the Jurassic suddenly changes to calcareous and sandy shales, abounding in fossils. This series, as well as the Trias, appears to liave been laid down horizontally in shallow waters.

Next comes the Cretaceous system-a mass of yellow sandstones with clayey and marly shales, aggregating from 4,000 to 5,000 feet thick. In this series we find an abundance of plant remains, many beds of gool coal, and mucl carbonaceous shale. The conditions during the Creta. ceons appear to have been quite similar to those which prevailed in the Appalachian region during the Carboniferous. Perhaps the conditions which attended and rendered possible the accumnlation of coal are not sufficiently well understood to enable us to say confidently just what they were, but there siems to be a general agreement that they involved a flat, low, moist country lying almost exactly at mean sea-level, and subject to alternate emergence and submergence. No other supposition seems to meet the requirements of the case, or to be capable of explain. ing how a mass of strata could be so accumnlated, consisting of alternations of thin seams of coal and carbonaceous shale witl layers of sand. stone containing marine fossils.

We have now the following remarkable state of affairs. From the close of the Carboniferous to the close of the Cretaceous there is strong evidence that the surface of deposition was always very near to sealevel, sometines a fer feet above it, but for the most part a little below it. And yet in the interval abont 9,000 feet of strata accumulated witl remarkable uniformity over the entire province, and always in a horizontal position. From this it necessarily follows that the mass of material thus deposited sank or "subsided" at a rate which, in the long run, was exactly or sensibly equal to the rate of deposition.

At the close of the Cretaceons we find evidence that the long calm which had characterized the action of the plyysical processes was in. vaded. Some extensive disturbances took place, resulting at some places in the dislocation and flexing of the strata, and the elevation of some portions of the region to considerable altitudes. Erosion at once attacked the uplifted portio $\mathrm{s}$, and around the borders of the province we find numerous localities, usually not rery extensive, which were greatly devastated. At some of these places the entire local Cretaceous series was denuded, and even a portion of the Jurassic; and the Tertiary is seen lying upon the Jurassic and across the beveled edges of the

5 G A 
flexel Cretaccous strata. But eren these localities were again submerged, as the presence of the Tertiary fully attests. These distmrbances were not general-did not extend to the. entire province, but alpear to have occurred around, or a little within, its marginal portions.

The last period of deposition was malked by the acemmlation of the Eocene beds, which form such a striking feature in the stratigraphy of the peripheral parts of the Platean eountry. Around the southern flanks of the Uintas their aggregate thickness exceeds 5,000 feet, but southward the mpper members disappear, and 50 miles north of the Grind Cañon only about 1,000 to 1,200 feet, representing the lowest portion of the series, make their appearance. It is highly probable that the middle and upper portions of the Eocene were never deposited there. But the lowest beds, most probably, once covered the entire plovince, while the midhle and late Eocene were eonfmed to its more northerly portions. The lowest nembers were deposited in brackish water, as their fossils amply attest; but in the suceeding beds the fossil forms are entirely those which live in fresh water. From that epoch to the present time there has been no reeurrence of marine conditions.

We now reach a turning point in the listory of this region. 'lhat long eontinuance of marine conditions lasting from the beginning of Carboniferous time to the elose of the Cretaceous eame grarlually to an end. 'l'he waters became brackish and then fresh. During the prevalence of the mariue condition it seems to be a necessary conchusion that the waters which covered it har abundant access to the ocean. Whether its waters were wide open to the ocean, like the Gulf of Mexico or Hurlson's Bay, or whether they formed a broad expanse, with a comparatively narrow ontlet, like the Mediterranean, we lo not know, and it would be useless to conjecture at present. At all events the communieation was sufficiently free to maintain a degree of saltness suitable to the existence of mollusean forms of the ordinary marine trpes. When the waters becane brackish, we infer that the straits became greatly narrowed; when they becane quite firesh, we infer that the aceess of the ocean to the area was wholly shut off, and that the water bronght by the rivers and rains merely outflowed, and the region became in inland lake of vast proportions. For the deposition still went on. 'Through Eocene time from 1,000 to 5,000 feet of lacustrine beds, containing an abundance of fresh-water fossils, were deposited. Among them are also found layers of coal and carbonaceous shales, and sandstones thielily imprinted with the traces of arboreal vegretation.

But at leugtli the deposition of lacustrine strata ceased; not, howerer, at one and the same time in all parts of the province. The evidenee indieates that in the soutlern and southwestern portions it stopled atter about one-fourth or one-third of the Eocene horizons had been laid down. In the central portions it appears to lave ceased after abont one-half to two-thirls of those horizons had been deposited. In the northern portions, in the vicinity of the Uintas, the entire system of Eocene 
strata is fonnd in immense volnme. 'These facts lead us to infer that the great Eocene lake, soon after its waters became quite fresl, began to shrink its area, and that its bottom became through a slow progression dry land. The sonthern and sonthwestern portions were the first to emerge; then the miadle portions; the lake gradnally retracting its boundary to the northward, until in the latter part of the Eocene it occmpied a greatly diminished area in the vicinity of the San liafacl country and the southern base of the Uinta Mountains. At the close of the Eocene this remnant of the lake also disappeared.

We now reach another turning point in the listory of the region. Hitherto and for an immense stretch of geological time it had been an area of deprosition and of subsidence. It now became an area of eleva. tion and denudation, and these processes have been in operation erer since. In the periods of deposition and subsidence, from the Carboniferous to the Eocene, both inclusive, the thickness of the strata acenmulated varied from 14,000 to 20,000 feet, and the smbsidence of the base of the Carboniferons was of nearly equal extent. In the periods of elevation and denndation these vast masses of strata rose bodily np again; the annount of elevation varying according to locality from 6,000 to 18,000 feet. 'The havoc wronght by erosion has been, as already shown, stnpendous; the thickness of strata removed exceeding 10,000 feet in some considerable areas, and averaging probably 5,500 to 6,000 feet over the entire province.

The points which it is lesirable to notice in this chapter concerning the progress of the Tertiary and Qnaternary erosion of the province, are few and of the broadest natmre. In truth it is necessary to speali very guardedly. For while the most general featmes of the work have left well-marked traces which can he interpreted, yet when we come to details the vast erosion has swept away so mnch of its mass that a large portion of the evidence of the details has vanished with the rocks. There is reason to believe that the greater part of the demudation was acconplished in Miocene time. 'This was a period of slow but continnous np). lifting, reaching a great amomnt in the aggregate, and it was most pron. ably also a period of rapid erosion. The uplifting, however, was nn. cqual in the different parts of the province. The comparatively even floor of the old lake was deformed by broad swells and plateans rising above the surrounding comtry. As we shall see hereafter, the action of the denuding agents is much more rigorons and efficient upon the higher than mpon the lower parts of a region; and consequently these up.swellings at once became the objects of special attention from the destroying forces and were wasted more rapidly than the lower regions around them. Here were formed centers or short limited axes, from which erosion proceeded radially ontwards, and the strata rising gently towards them from all directions were beveled off. Thus were formed those areas of maximm erosion, already spoken of, and of which the San Rafael Swell is the most perfect and simplest type. 
We have also reason to believe that the climate of the Miocene was moist and snbtropical, eonditions fivorable under the ciremmstanees to a lapid rate of crosion. We do not indeed find the proof of this in the province itself, for it eontains no Miocene strata or fossils; bnt in surronnding regions the strata and fossils of that age are found in abundance, and they clearly indieate that the elimate had that character; and it wonld be quite untenable to snppose that so limited a tract as the Platean Province was an anomaly in respeet to the climate of the broader regions of which it is a part, mless special reasons for it eonld be adduced. I know of no suelr speeial reasons. But near the close of the Miocene, or not long thereafter, the climate of almost the entire West underwent a change, beeoming arid, as it is at present. In this change the Plateau comtry no doubt shared. The more important results of the Pliocene and Quaternary erosion, however, will be among the prin. cipal themes of the following chapters. 


\section{CHA P T E R I .}

\section{GEOGRAPIHY OF THE GRAND CAÑON DISTRICT.}

The Grand Cañon District-the region draining into the Grand and Marble Cañons-is the westernmost division of the Plateau Province. Nearly four-fiths of its area are situated in Northern Arizona. The remaining fifth is sitnated in Sonthern Utah. Let us turn our attention for a moment to the portion situated in Utal. It consists of a series of terraces quite similar to those which we have already seen descending from the snmmit of the Wasatch Platean to the San Rafael Swell like a colossal stairway. At the top of the stairs are the broad and lofty platforms of the High Plateans of Utah; at the bottom is the immer expanse of the Grand Cañon District. The summits of the High Plateaus are beds of Lower Eocene age. Descending sonthward we cross, step by step, the terminal edges of the entire Mesozoic system and the Permian, and when we reach the inner floor of the Grand Cañon District we find that it consists of the summit beds of the Carboniferous series pateher here and there with fading remmants of the Permian.

Fan beyond the remotest limits of vision stretches the great expanse of Upper Carboniferous beds, flecked with Permian outliers, and rising or falling to form the broader inequalities of level in the surface of the region. The terraces of Sonthern Utah are the border land between the High Plateans on the north and the Carboniferons platform of the Grand Cañon on the sonth, and may be regarded as the appanage of eitler district. 'Their nature and meaning may becone clearer by glancing a moment at the District of the High Platerus.

Let us conceive a right-angled triangle in which the acutest angle is regarded as the apex and the shortest side as the base. Place the apex about 25 miles east of Momt Nebo, the great mountain which marks the southern end of the true Wasateh Range; place the right angle 170 or 150 miles due south of the apex, and the other acute angle abont 100 to 110 miles due west of the right angle. This figure would inchude pretty nearly all of the summit areas of the High Plateaus. Consider now the north-and-sonth side reaching from the apex to the right angle. It ruis along the crest lines and terraces which look down eastwardly upon the San Rafael district and upon other enormously eroded districts further sonth. The base reaching westward from the right angle to the other acute angle runs anong the terraces which descend from the southern termini of the High Plateaus to the Grand Cañon District. The hypothenuse loolis northwestward over a portion of the Basin Province. The High Plateaus themselves are large remnants of Mesozoic 
and 'Tertiary strata which have been spared in the enormons denudation which has eaten out the heart of the Platean Province. 'Their preser ration las been largely due to extensive outpours of lavas, which have overspread most of their summits, and the energy of the eroding ageneies has there spent itself upon the more obdurate materials of voleanie origin.

Starting from the right angle and reaching ont south-sontheast is a lather lofty mass, named the Kaiparowits Platean. It reaches to the Colorado River, where it is cleft. asumder by the mighty gorge of the Glen Cañon, but resnmes its course on the other side, extending into Arizona, where it spreads ont. It is composed of Cretaceous strata. Its western llank forms a part of the eastern bonndary of the Grand Cañon, or more restrictedly of the Marble Cañon, distriet. Here again is the sane old arrangement--terraces with their marginal eliffs rising from the Carboniferons platform step by step to the Middle Cretaceous-the eliff's all looking westward over the great region from which the former extensions of the strata they terminate have been swept away.

'Thus we may note that the northern and eastern bomdaries of the Grand Cañon Distriet are eliff-bonnd terraces. Crossing the distriet either longitudinally from north to south, or transversely from east to west, we find as we approach the sonthern or western border that the Carboniferous platform ascends very gradualy. There are broad and feebly marked (sometimes well marked) muchlations, or ups and downs; but, on the whole, the country gains in altitude as we approach its western and sonthern limits. At last it terminates in is giant wall plunging down thousands of feet to the platform of a combry quite similar to that of the Great Basin of Nevada. Those who have traveled on the Central Pacific Railway will recall the features of that very desolate region whieh lies between Great Salt Lalie and the Sierra Nevada; and all those features are repeated and their desolation intensified in the dreadful region which lies west and south of the Grand Cañon Distriet.

The district may be conveniently divided into parts. 'The northernmost portion is the area comprising the sonthern terraces of the High Plateans. A deseription of these sufficient for prelininary purposes lats ahready been given. At the foot of these tero aces stretches away to the sonthward the great Carboniferous plattorm of the heart of the district. 'That portion of the platform which lies north of the Colorado River maly be subdivided into five distinct plateans. Naming them in regnlar orler from west to east, they are: 1, the Shearwits; 2, the Uinkaret; 3 , the Kanab; 4, the Kaibab; 5 , the Paria. These five plateans are separated from each other by natural boundaries, which are for the most part quite distinct. These boundaries are great finlts or dislocations of the main platform, which have produced eliffs by hoisting the platform on one side of the fault line or dropping it on the other. 'To show how these disloeations have aftected the topography, the reader is referred to the east and west section delineated in the accompanying dia- 


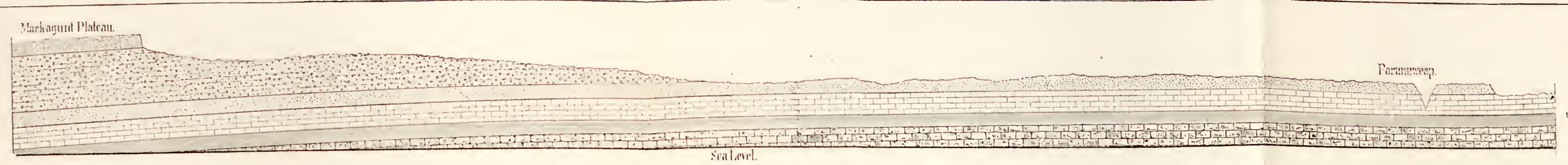

\section{Vermilion Cliffs}

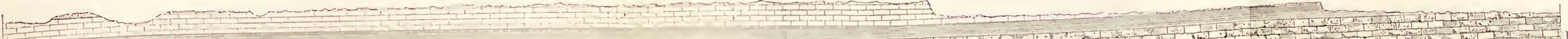

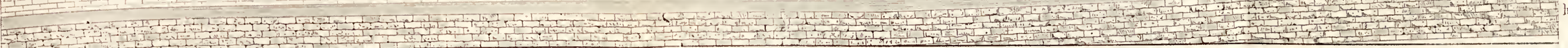

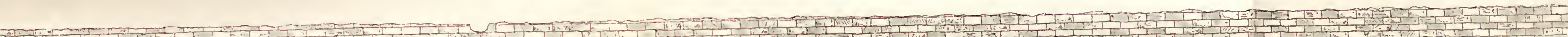

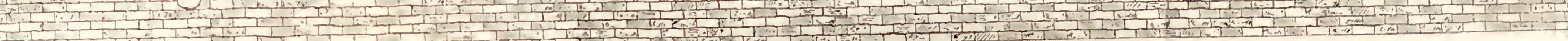

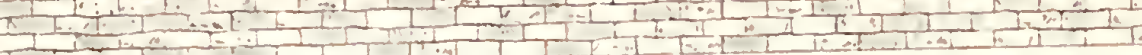

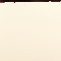

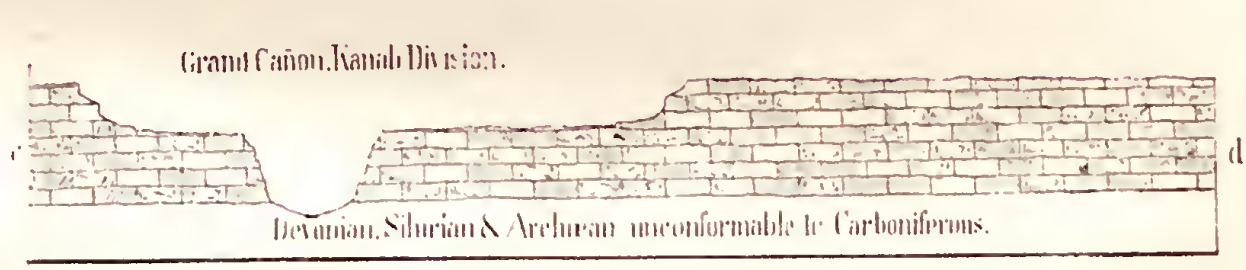
Aa intervil of illirty
nuiles innwhicht llie strial
irre horizuntitil.

ar,

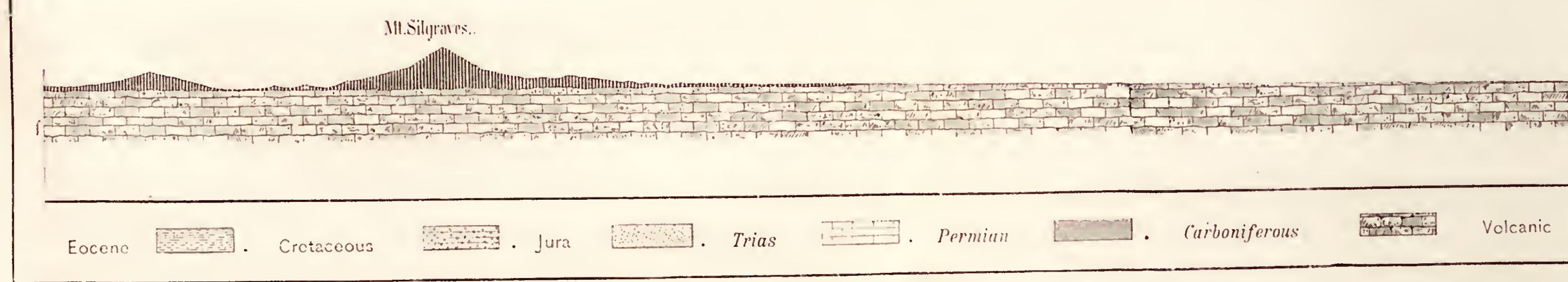


gram. (Pl. XIII.) Immediately sonth of the Paria Platean extends the Marble Cañon, with a sonthwestward course. Directly across the remaining four plateaus winds the Grand Cañon of the Colorado. South of the river is a vast expanse of nearly flat surface, but little diversified, called the Colorado Plateau. Upon its southern borders rise abruptly a group of great voleanic piles ealled the San Francisco Momtains, the largest or dominant cone being of an impressive order of magnitude. There are still other portions beyoud, but the entire region south of the Colorado has been recommoitered rather than surveyed; and though we have a general knowledge of pretty uearly the whole of it, onr knowl. edge of details is not as yet precise.

The entire expanse of the Grand Cañon platform within the terraces consists of a flat surface, intermpted at wide intervals by clifis or sharp flexures produced by the great displacements which traverse the land in a prevailing north to south direction.* On the whole, it is a smooth comntry in comparison with the other districts of the Platean Province. It is not dissected or honeycombed by the ramifications of inmmerable side gorges, as is the case with most of the other districts, for the Grand Cañon has on the north side only one lateral or tributary eañon of any considerable length, and this tributary has but few branches. In truth, one of its remarliable features is the pancity of lateral chisms. 'The sonthem side is not more diversified than the nothern, and I think we may say that it is somewhat less so. Between the great clifts of dis. placement and between the foot of the teraces and the brink of the chasm the comntry is not more meven than the Great Plains of W Vestern Nebraslia and Kansas, and not much more so than Indiana and lllinois. But the traveler is seldom out of sight of the palisades reared at the funlt-lines, or of the gigantic and gorgeomsly colored walls which bound the terraces of the High Platems.

The Grand Cañon will be described at some length in subsequent chapters. Here will be noted only those more general features which may be male to appear on the map. It crosses transversely the four western plateans of the district, while the Marble Cañon traverses the eastern or fith plateau. The two cañons are only nominally separated, for there is no wap between them. The Marble Cañon begins at the base of the eastern terraces. The Coloralo liver, after traversing the central mesas of the Platean comtry in a series of profonnd chasms, at length energes from the Eeho Cliffs of Triassic and Perminn age. Here for an instant the river is in comparatively open country. But within a mile or two it begins to sink another chasm in the Carboniferous rocks, and in the course of 65 miles the depth steadily increases until it becomes abont 3,500 to 4,000 feet. This is the Marble Cañon. It is

\footnotetext{
* It will be noted here that clifls may bo produced (1) by fanlts lifting the country on one sivle of the finlt-line or depressing it on the other; ( $\approx$ ) by the demudation of the strata in front of the cliff. The formerarecallul Cliffs of lrisplacement; the Fatter. Cliffs of Erosion.
} 
a gorge of very simple form, and its widtl is about twice as great as its depth. Its course is at first sonthwest, bnt gradually deflects to the southward. Its lower end is arbitrarily fixed at the junction of the Little Colorado or Colorado Cliquito, a stream coming in from the soutlieast and entering by a lateral chasm as deep as the main gorge itself. Below this junction the river turus westward, the walls grow rapidly higher, the great chasm widens out to six or eiglit times its width in the Marble Cañon, and the valley of the river is filled with buttes as large as mountains and wonderfully sculptured. Here the liver enters the Kaibab, and its walls soon attain the altitude of about 6,000 feet. After a tortuous course of sixty miles in a prevailing northwest direction the river passes out of the Kaibab and at once changes its trend to west southwest. It passes without a break from the Kaibab to the Kanab Platean. Here its depth diminishes to about 5,000 feet and its topograply clanges in character, becoming more simple. Preserving its new features and the direction of its course throughout the Kinab and Uinkaret plateaus, it at length crosses the Hurricane finlt where the whole platform of the country suddenly drops more thin a thousand feet, correspondingly diminishing the heiglit of the walls. But the lost altitnde is steadily and rather rapidly regained as the river enters the Slrearwits Platean. Soon after crossing the fault the river turis abruptly to the south, and after describing a great curve in the heart of the Shearwits platform it turns northwestward again. The great chism sucklenly terminates in the face of the giant wall which forms the western boundary of the Slieavwits Plateau. Here the river emerges through a miglity gateway a mile in depth, and is almost in open country, its banks dropping at once to altitudes of only a few hundred feet. This is the westem bound, not only of the Grand Cañon District, but of the Platean Province itself. Thenceforth the course of the Colorado to the ocean is throngh and aeross that dismal, torrid sierra region, which is the sonthward extension of the features of the Great Basin.

For convenience of discussion the Grand Cañon is divided into fonr divisions, (1) the Kaibab, (2) the Kanab, (3) the Uinkaret, (4) the Sheavwits, divisions. The last three are much alike in all their features and dimensions. The Kaibab division is a little deeper, notably wider, and very much grauder and more diversified than the others. The total length of the Grimd Cañon, as the river rmo, is about 218 miles, and its depth varies from 4,500 to 6,000 feet, averaging 5,000 . Its width, from crestline to crestline, varies from $4 \frac{1}{2}$ to 12 miles-the widest portions being always the grandest.

It is also necessary to advert to the tributaries of the Colorado lying within the district. Upon the northern side there is bnt one now entering the Grand Cañon; but there are on this side two others, one of which, nimed the Paria, enters at the liead of the Marble Cañon, and the other, the Virgen, which enters it abont 40 miles west of the lower end of the 

Grand What Grand Wash Full

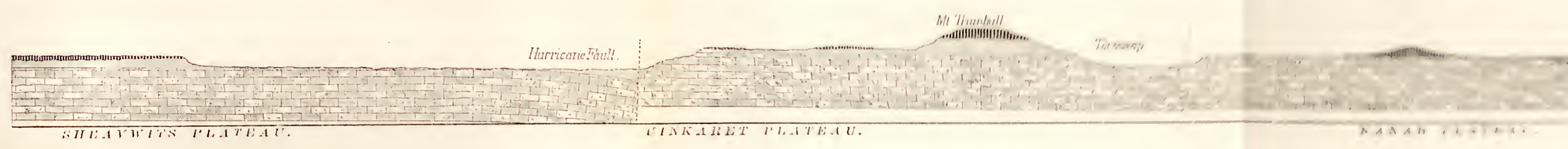

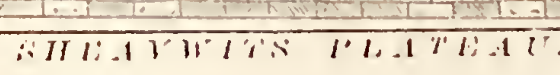

liariab Canon

We nawastive P.

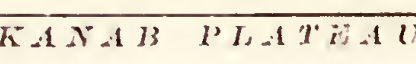

West KaibabFa $u$ ll $:$ Niol

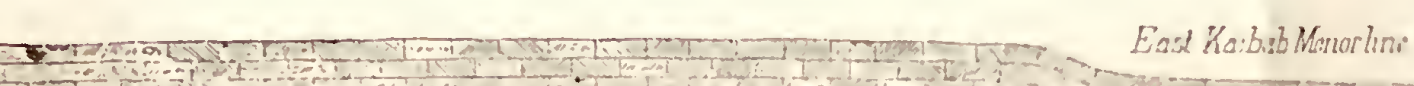

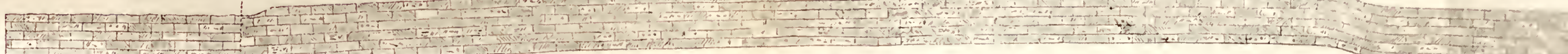

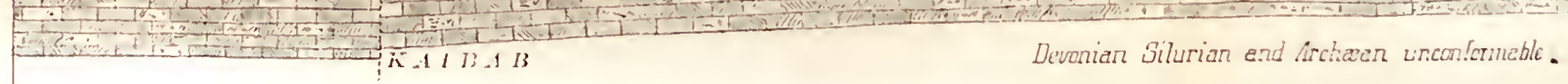
Sra Leruch PLATRAT:

Echo Cliffs.

Fत

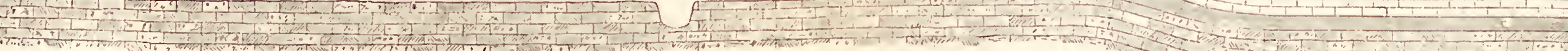

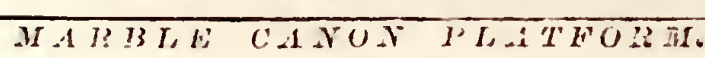

\begin{tabular}{|c|c|c|c|}
\hline Volcanic & 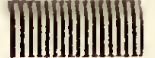 & Trias & $E_{1}-1$ \\
\hline Cretaccous & & Permian & $1-$ \\
\hline Jura & 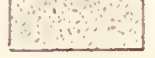 & Carboniferous & U1 \\
\hline
\end{tabular}


Grand Cañnn. Kanab Creek joins the Colorado on the north side in the heart of the great chasm. These three streams, the Virgen on the west, Kanab Creek in the middle, and the Paria on the east, all have their sources in the terraces of the High Plateaus. They are very impor. tant factors in the problem of reconstructing the history of the region.

On the sonth side of the river are (1) the Colorado Chiquito or Little Colorado, entering at the foot of Marble Cañon, (2) Cataract Creck, entering near the middle of the Kanab division, (3) Diamond Creek, joining at the elbow of the great bend in the Shearwits division. These, too, have their bearing upon the general problem. 


\section{H A P'T'E R III.}

\section{THE TERIACES.}

In describing those subdivisions of the Grand Cañon district which are of greatest moment to the present disenssion, I shall begin with the terraces terminating the High Plateaus.

Before the observer who stands upon a southeru salient of the Mar kágunt Platean is spreal out a magnificent spectacle. The altitude is nearly 11000 feet above the sea, and the radius of vision reaches to the soutlrward nearly a hundred miles. In the extreme distance is the ealm of the desert platform, its surface mottled with indistinet lights and shatles, too remote to disclose their meaning. A gainst the sont lieastern horizon is projected the pale-blue escarpment of the Kaibab, which stretches away to the south mntil the curvature of the earth earries it out of sight. To the southward rise in merest outline, and devoid of all risible details, the dark mass of Mount Trumbull and the waving cones of the Uinkaret. Between these and the Kaibab the limit of the prospect is a horizontal line, like that which separates the sea from the sky. To the southwestward are the Sierras of the Basin Province, and quite near to us there rises a short but quite lofty range of veritable unomtains, contrasting powerfully with the flat crestlines and mesas which lie to the south and east. It is the Pine Valley range, and though its absolute altitude above the sea is smaller than many other ranges of the West, yet since their bases are comparatively low $(3,000$ to 3,500 feet above the sea), the momtain masses themselves are very high.

\section{THE EOCENE.}

The foreground of the picture is full of strength and animation. At our feet is the brink of a precipice where the profiles descend s00 feet upou rugged slopes which shelve away dowuwards and mingle with the inequalities of a broad platform deeply indented with pieturesque valleys. The eliff on which we stand is of marvelons sculpture and color. The rains have carved out of it rows of sqnare obelisks and pilasters of uniform pattern and dinensions, which decorate the front for many miles, giving the effect of a giantic colonnade from which the entablature has been removed or las fallen in ruins. The Platean Country abounds in these close resemblances of matural carving to human architecture, and nowhere are these more couspienous or more perfect than in the 


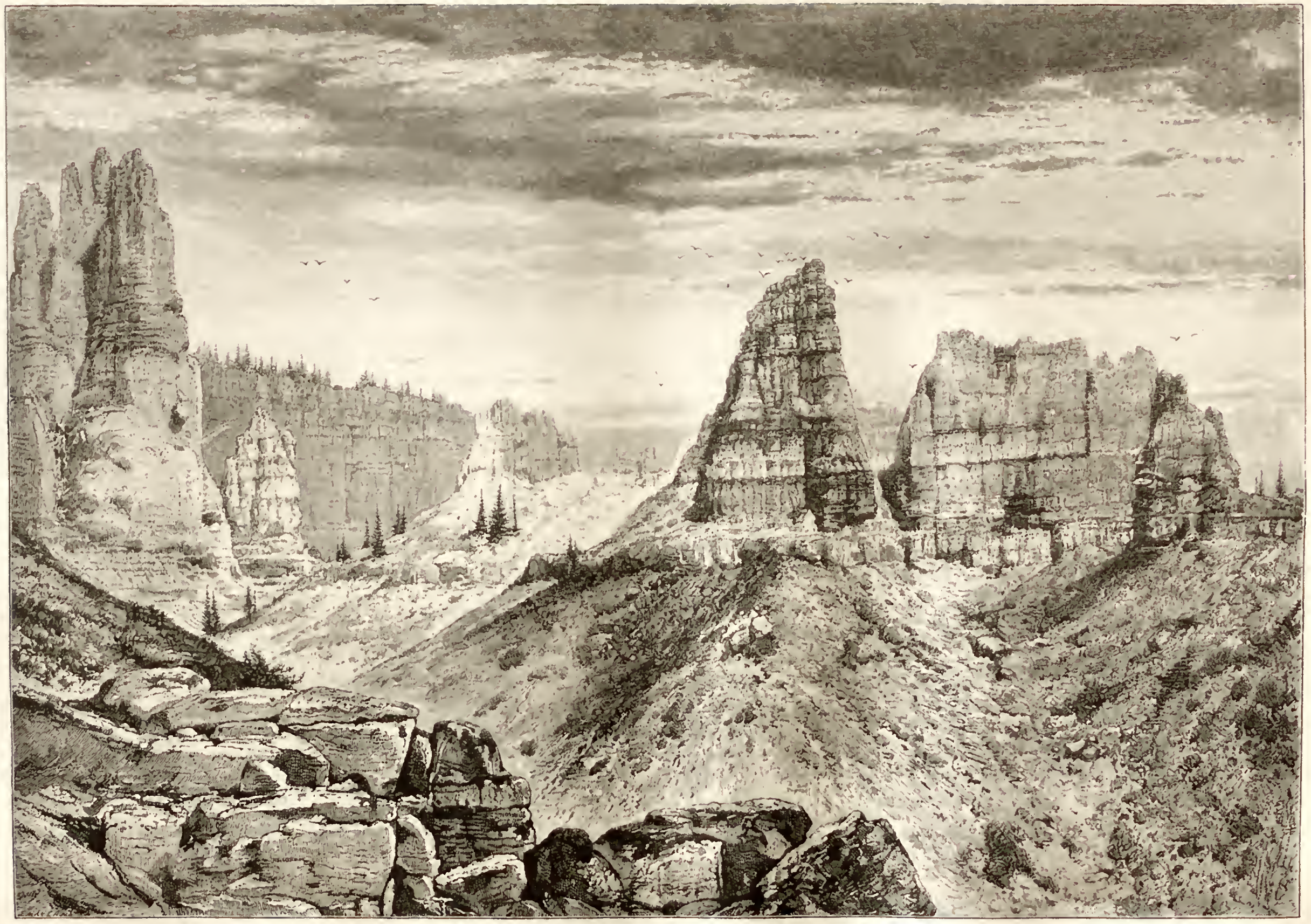

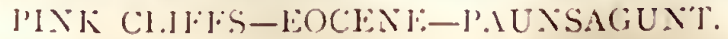


scarps which terminate the summits of the Markígunt and Paunságunt Plateaus. 'Their color varies with the light and atmosphere. It is a pale red under ordinary lights, but as the sum sinks towards the horizon it deepens into a rich rose color, which is seen in no other rocks and is beantiful beyond description. These eliffs are of lower Eoeene age, consisting of lake marls very uniformly bedded. At the base of this series the beds are coarser, and contain well-marked, brackish-water fossils; but as we aseend to the higher beds we find the great nass of the Eoeene to consist of fresh-water deposits.

These beds are identical in age with the lower divisions of the Eocene which are seen in great volnme both north and sonth of the Uinta Mountains, in the basins of the Green River, of Bitter Creek, and of the White and Uinta River's. Their geological relations and associations, too, are quite the same, for the same lake bottom received the deposits of the southern Uinta slopes and those of the Markígunt. Those of the Green River basin north of the Uiutas appear to have accumnlated in a sepalate lake basin commmicating with the one which snbmerged the sonthern Platean province. The interval separating the Marlágunt from the Uinta region is 250 miles and more, but the lower Eocene is continnons between them. It occmpies a marginal belt sometimes narrow, but more frequently wide, which was once the locus of the northwestern portion and shore line of the great lake. The summits of the High Plateaus, wherever the voleanie masses are absent, diselose this formation, and its presence is decisively inferred beneath the lavas and their débris. A conmon bond between the two regions is also indicated by the physical conditions attending the deposition of these strati. 'The lower Eocene rests mpon the mulerlying formations, conformably in some places, nnconformably in others. Where conformity prevails, both the mpper and lower series were at the time of deposition seusibiy horizontal. But in many places the Cretaceous, prior to the deposition of the Eocene, was greatly disturbed and greatly eroded. And in general the base of the Eoeene marks an epoch in the geological history of the country, in which an old order of events was closing and a new order was making its adrent. 'This revolution was the transition of the region from the oceanic comlition to that of an estuary aud lake, and subsequently to that of dry lamb. The Lower Eocene beds are brackish-water deposits in the basal members, while higher mp they become fresh-water. The basal members are coarse and even eonglomeratic in their texture, while the middle and higher ones are fine and marly. Thus is indiented the complete severence of the lake from the aceess of oceanic waters. Both in the Uinta distriet and thronghont the High Plateaus these events are recorded in the same order and their meaning is the same in both.

The beds now found in the sonthern extremities of the High Plateans represent less than half of the dnration of Eoeene time. No middle and no npper Eoeene strata are found there. But as we go northward towards the Uintas we find later and later formations suc- 
cessively appearing until upon the flanks of the Uintas we find the whole Eocene series in enormous volume, exceeding perhaps 5,000 fcet. Could these middle and Upper Eocene masses once have existed upon the sonthern portion of the High Plateaus and been swept away by erosion? There is strong evillence to the eontrary.* 'Ihe facts, then, indicate that when the desiecation of the lake took place, the portion whiel first emerged was the southern and sonthwestern-or the Grand Cañon district; that its shore line gradually receded northward during middle and upper Eoeene time, leaving dry land behind it; and the last remnant of the lake disappeared near the base of the Uintas. Wherever the physical geology and evolution of the Grand Cañon distriet touches the ques. tion of time, the earlier date of its emergence than that of other portions of the Platean Provinee appears-sometimes dimly, sometimes forcibly.

The prineipal mass of the Eocene terminates at the "Pink Cliffs," as they are called, in the sonthern margins of the Markigunt and Paunságunt Plateaus. There are a few ontliers beyond. Alound the base of the Pine Valley Monntains to the sonthwest, and beyond them in the same direction, some remmants have eseaped destruetion. But this part of the eountry has not been sufliciently explored to indicate more than the bare faet of their existence. Far to the eastwarl a single ontlier stands upon the summit of the great Kaiparowits Platean, forming the apex of Kaiparowits Peak. But generally speaking, the Eoeene is wholly absent, so far as known, from the eountry south of the terraces.

\section{THE CRETACEOUS.}

The platform immediately below the Pink Cliffs is pieturesque rather than grantl. Rough rolling ridges of yellow sandstone, long sloping hillsides, and rocky promontories elad with large pines and spruees, surround the valleys. 'These roeks are of Cretneeousage. Upon the southward slopes of the Paunsagunt and Markagunt Plateaus, they nowhere present the serried fronts of eliffs, but break down into long irregular slopes much like those of common hill countries. In those superficial and merely seenic aspects whieh make the terraces so impressive, the Cretaecous is for the most part notably deficient; but in those (leeper studies, which are of most signifieance to the geologist, it holds an inportanee not inferior to that of any other formation. It is never wanting at its proper place in the terraces, but always displays a vast series of sandstones and clay-shales, varying from 4,000 to 5,000 feet in thickness. Around the western and southern flanks of the Markagunt, and just beneath the summit platform, they occupy a belt varying in width from 4 to 10 miles. Around the Panságunt their relative positions and re-

*This evidence will be fully discussed in my monograph on the Geology of the Grand Cañon district.-C. E. D. 
lations are quite the same. But as we pass eastward into the great amphitheater of the Paria Valley they at length take the form of cliffs of very striking aspect. The muncrous ledges rise in quick succession, step by step from the valley bottom to the base of the Eoecuc mass of Table Cliff, which stands as a glorious Parthenon npon the summit of a vast Acropolis. The many superposed cliffs which constitute this stairway are screrally of moderate dimensions, but their cumulative altitude is more than 4,000 feet, ticr above tier, and their compositc or multiple effect, intensified by the excceding sharpness of the infinite details of repetitive sculpture, places it among the grander spectacles of the Platean country. In their coloring, thesc eliffis are quite peculiar. There are $n$ red, purple, orange, and chocolate hes, such as prevail in other formations, but pale yellow and light brown in the sandstones and bluegray to dark iron-gray in the heavy belts of slale. 'The tones are very light and brilliant on the whole, the darker belts playing the part of a foil which angments rather than diminishes their luminosity.

THE JURASSIC.

Beyond the Cretaceons, as we descend the stairway of terraces, the Jurassic comes to daylight. It forms a belt cncircling the Cretaceous and outside of the latter. It is composed of two groups of strata; the upper consisting of red sandy shales witl belts of impure limestone; the lower a great mass of white sandstone, ncarly a thousand feet thick. The red shales contain abundant fossils, strongly eharacteristic of their Jurassic age, while the sandstonc below is wholly barren of organic remains. 'The sandstonc, howcrer', is full of interest on account of its remarkable lithological characters. From snmmit to base, it is apparently one indivisible stratnm. Here and there signs of a division are suspected, but closcr scrutiny shows that they are produced by the contact of one plexus of cross-bedding with another, or by some otler cause not affecting the dominant fact. It is remarkably homogeneous thronghout its whole mass. On a near view of the rock fuces they are seen to be covered with a wonderful filagrce of cross-bedding. On every cliff and headland, on cvery butte or rocky knoll where this huge stratnm is cxposel, the rock faces are etched with an arabcsque as beantifnl as frostwork. Along hundreds of miles of linear cxtent, and over thonsands of square miles of surface of the country, this graceful waving of myriads of curves is displayed. Cross-bedding is common enongh in other regions and other formations, bnt nowhere in the world, I fancy, can such a profusion of it be scen.

The Jnrassic sandstonc is also conspicnons for its cliffs. Herc every formation las its own style of architecture and sculpturc, which are as distinctive as the lithological constitution, for npon that constitution 
the style depends. The Jnrassic forms are eharacterized by a peculiar massiveness and boldness and by an extreme simplicity wheh is eren severe. Its walls are quite plain, without horizontal or vertieal mouldings, and the only deeoration is the eross-bedding whieh becomes invisible at distances sufleient to render a general view of the fionts eflective. A notable feature also is the absence of talns-or, if it be present, its small proportions. This simplicitly usually gives a dull slumberous aspect to the escarpments, snggesting on a vast seale the structures of the Peruvian Ineas. Bnt it is not always so. Occasionally the auster. ity of these forms is relaxed or replaced by a strange lind of animation which sometimes beeomes amusing. Looking southward from the brink of the Markigunt the eye is attracted to the featnres of a broad middle terraee upon its southwestern flank, naned The Colob. It is a veritable wonderland. It lies beyond the Cretaceous belt and is far enough away to be obseure in its details, yet exeiting enriosity. If we descend to it we shall pereeive numberless rock-forms of nameless shapes, but often grotesque and Indicrons, starting up from the earth as isolated freakis of earving or standing in elusters and rows along the white walls of sandstone. They bear little likeness to any'thing we ean think of, and yet they tease the imagination to find something wheremto they may be likened. Yet the forms are in a certain sense very definite, and many of them look merry and fareieal. The land here is full of eomedy. It is a singular display of Nitnre's art mingled with nonsense. It is well named the Colob, for the word has no aseertainable meaning and yet sounds as if it ought to have one.

Nor are these the only forms whieh the Jurassie discloses. Here and there blank fuces of the white wall are brought into view as the sinuous line of its front advanees and reeedes. Isolated masses cut ofr from the main formation, and often at eonsiderable distanees from it, lie with a majestie repose upon the broad expanse of the terrace. These some. times become very striking in their forms. They remind us of great forts with bastions and searps nearly a thousand feet high. The smaller masses become regular truncated cones with bare slopes. Some of them take the form of great domes where the eagles may build their nests in perfect safety. But noblest of all are the white smmmits of the great temples of the Virgen gleaning through the haze. Here Nature has changed her mood fiom levity to religions solemnity; and revealed her fervor in forms and strnctures more beatiful than anything in linman art. But we shall see more of this hereafter and from much more ad vantageous stand-points than the smmmit of the Markágnnt. There only faint suggestions of the reality are given. We only perceive in imperfect detail some throngs of towers, snow-white above and red below, the bristling spires of ornate buttes, or a portion of the grand sweep of a wing-wall thrust out from some unseen façade. None of them appear in their full relations to the whole. and all of them are weakened, fided, and flattened by the distance. 


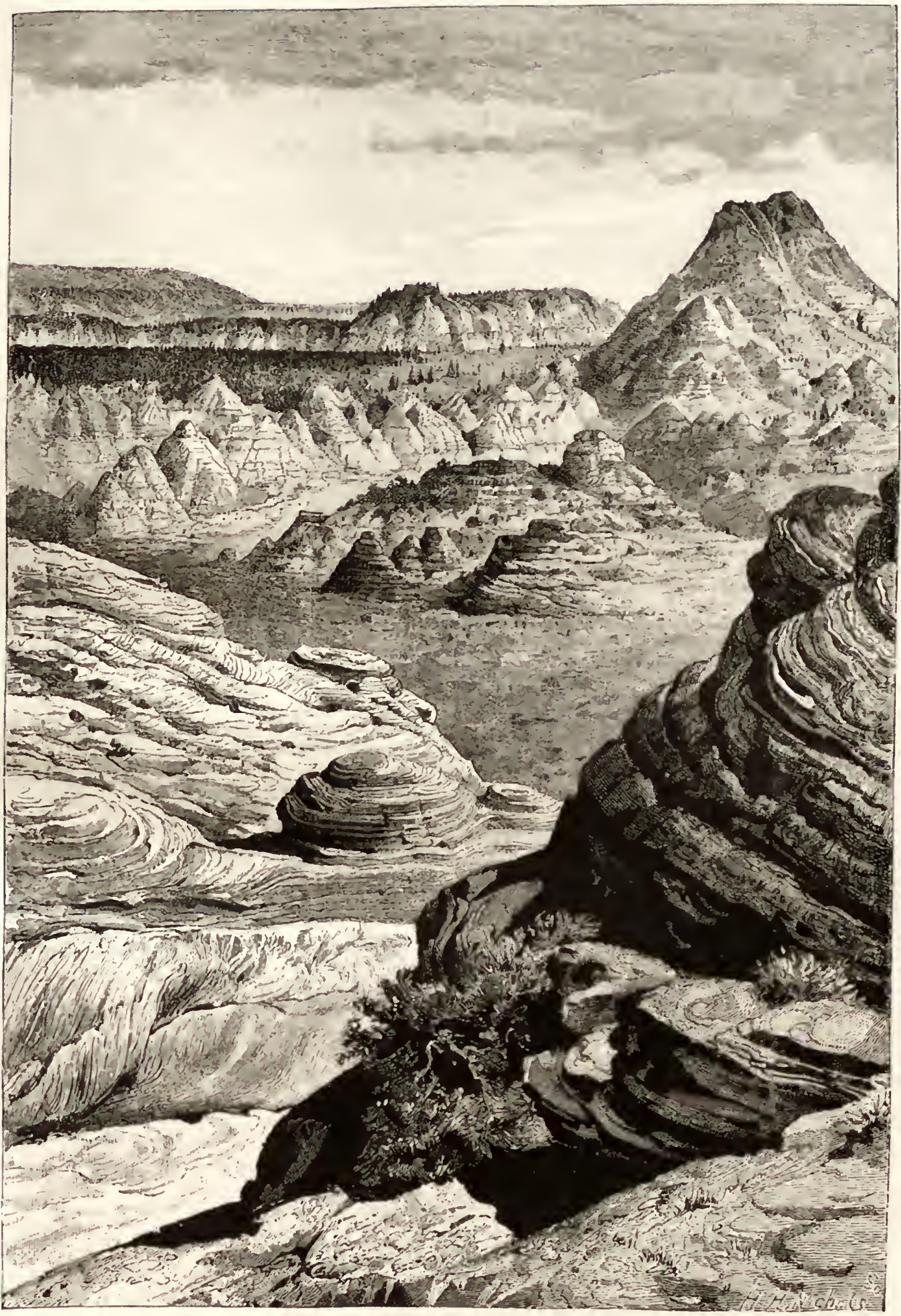

A MIDSUMMERDAY'S DREA II,-JURASSIC-ON THE COLOB. 
At the border of the Jurassie the profile drops upon the smmmit of the Tias, but from the summit of the Markágmethothing is visible in detail of that formation. The faces of the esearpments are turned away from IIs and only the crestlines are visible. The view from the Markigrunt, lowerer, is memorable because it is characteristic. 'To study the 'Trias we minst leave the verge of that Platean and descend the terraces to the southward.

On onl way we may note several things of some importance. We may observe, first, that the strata all have a very shight dip to the north. 'This dip on the average is less than two degrees, but liere and there inclinations as great as fom or five degrees may be seen. This dip is very gencral throughont the terraces. Its effect is to make the altiturles of the higher or more northerly platforms less-or, eonversely, to make the altitndes of the lower and more southerly terraces greater-than they wonld be if the entire serics were liorizontal. In the entire series of beds which are exposed, the aggregate thickness from the top of the Carboniferous to the summit of the local Eocene is not far from 10.000 feet, bnt the summit of the Eocene at present lies only about 5,000 to 6,000 feet above the Carboniferons platform of the Grand Cañon District. 'Thus, it' the strata were horizontal, we should in ascending the terraces go np) 10,000 feet, bnt the dip to the northward gradnally carries down the horizons so that in crossing the edges of 10,000 feet of strata we only gain 5,000 to 6,000 feet in altitude. We find this same northward dip prevailing in the Carboniferous to the sonthward, and it is a feature of great moment in the studies which are to follow.

Another point to benoted is that the strata slowly diminish in thickness from west to east. 'The attenuation, howerer, is ordinarily rery slow and gradual, and the observer would have to travel many miles along the escarpments exposing the edges of the strata before he be. cane aware of it. It is most noticeable in the Trias, and in the sequel this will be more fully discussed. The meaning of this attennation of the strata towards the east is as follows.

It is a common fact that the greatest thickness of a gromp of strata is usually found near the shorelines of the mainlands from which their materials came. As we recele from these ancient shorelines we generally find that the strata diminish in thickness, at first quite rapiclly, but afterwards more slowly. 'The materials deposited near the sliores are, in many cases, of coarser texture than those deposited at a distance from them. 'This is not always trine of every distinct bed, but if we consider any gromp of strata with many nembers we shall usnally find it true of the group as a whole. In the case of the Mesozoic strata of the terraces, they are remnants of beds deposited in a sea or bay, the shoreline of which lay to the westward and northwestwarl. The position of this shoreline, no doubt, varied during the Mesozoic periods, now advancing and now receding; but in general terms its mean position ap. pears to have been nearly along what is now the boundary of the Basin 
Province. The Great Basin was then dry land, undergoing demudation, and its detritus was washed down on this side into the sea, where the Mesozoic strata of the Plateau Province aceumulated. The position of this aneient shoreline in the Sierra conutry south of the Great Basin and west of the Grand Cañon distriet we do not as yet know; the pre. sumed location not being explored as yet. This attennation of the strata and their relation to the shoreline of the mainland, from whieh they were in great part at least derived, is another important faetor which must be kept in mind in the eonrse of the disenssion.

It will be well to bestow also a glance at the distribution of the more important drainage ehamels. 'The western portion of the terraces is

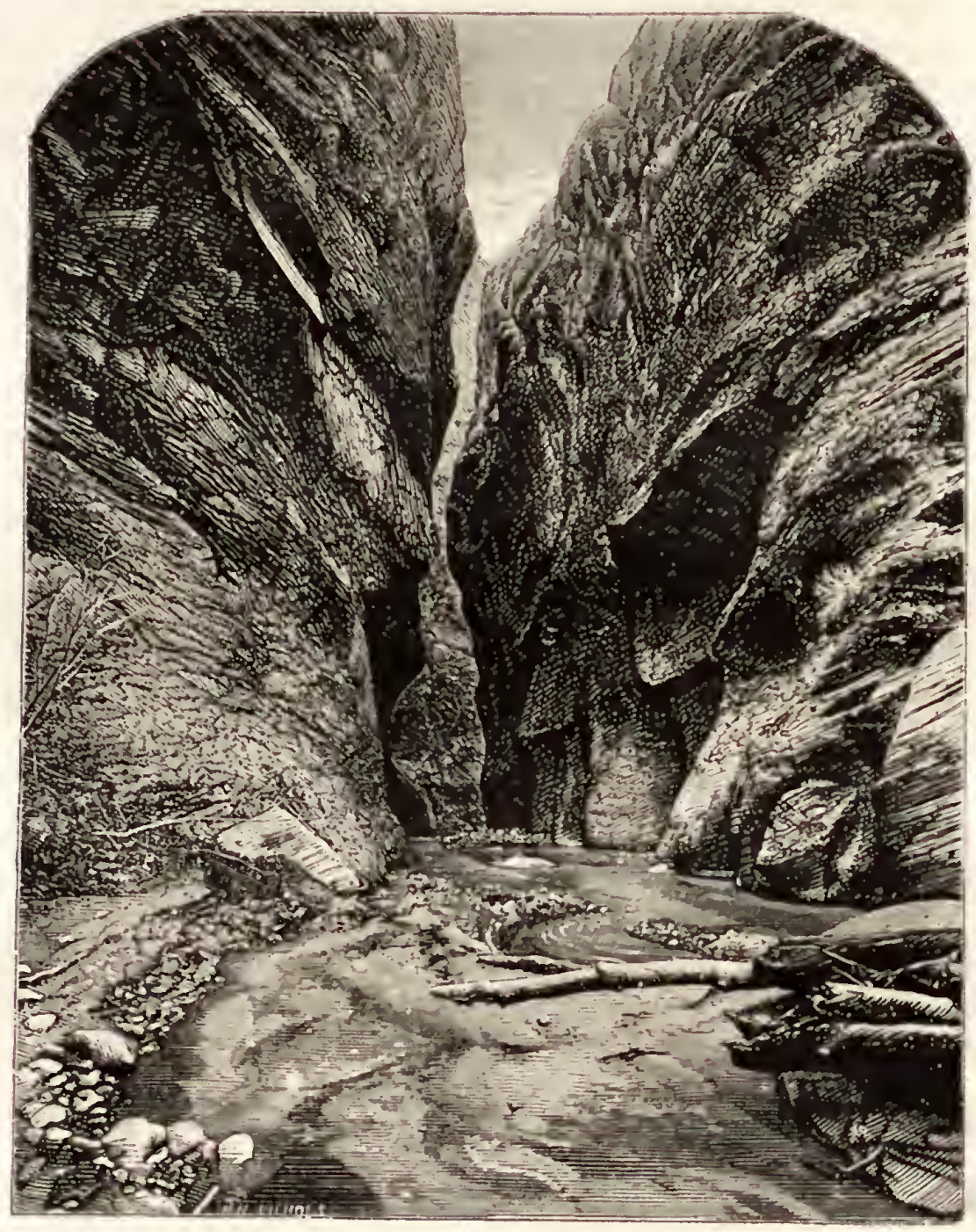

Fig. 5.-Futrance to the P'an'-nu-weap.

drained by the branches of the Virgen River. Upon the Colob heads the northern fork of the Virgen, sometines called the Mu-kún-tu-weap, sometimes Little Zion River. It flows due south. East of this is the eastern fork, called the Pa-rú-nu-weap). Both branches liave their sources at the base of the Pink Cliftis (Eocene), and at length unite to form the 


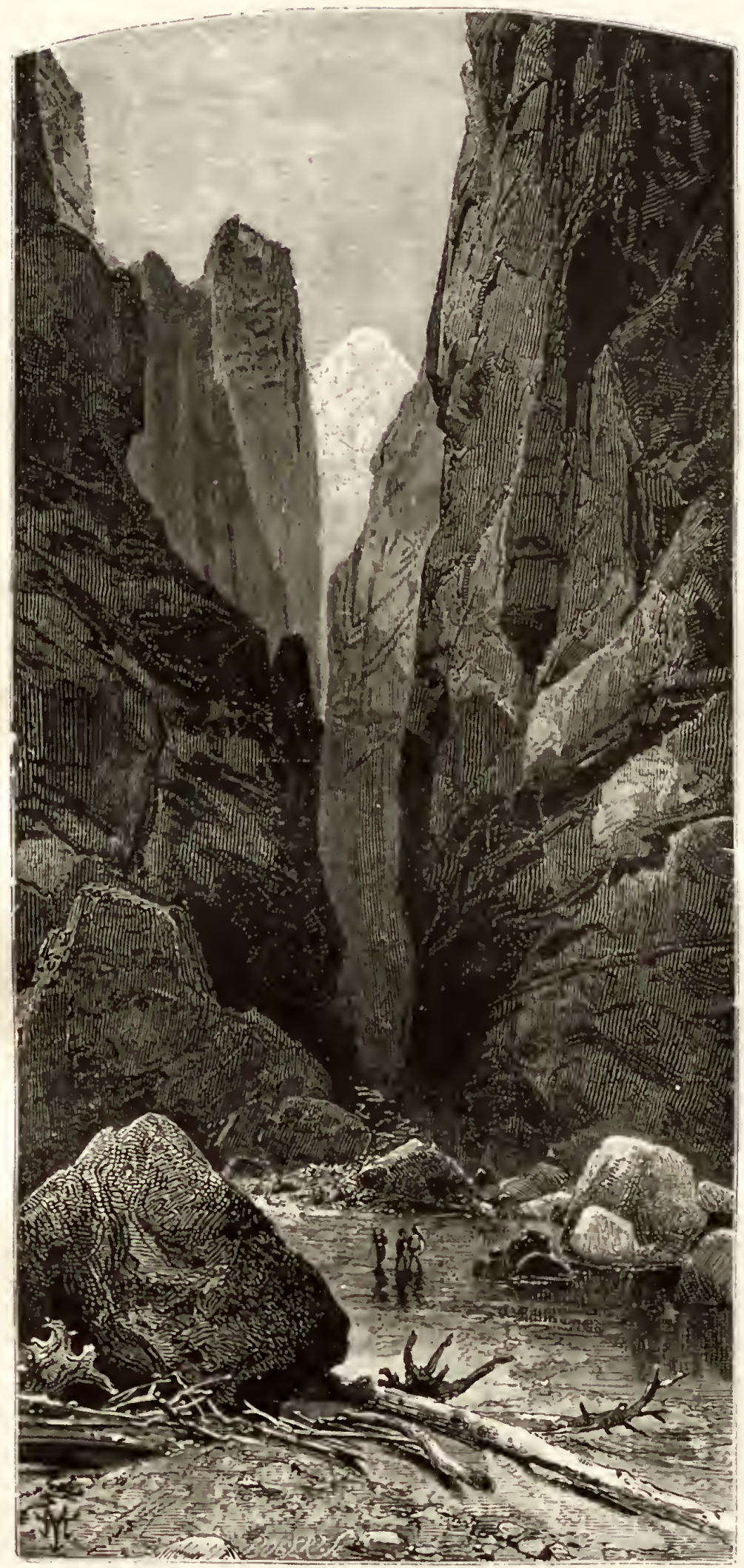

THE PARUNUWEAP.

From Powell's kxploration of the Colorado River. 
Virgen. 'Their channels are surely very wonderful fieaks of nature. 'The Parńnuweap, after colleeting its several filaments on the slopes of the Cretaceous terrace, at lengtl begins to burrow into the Jurassie, entting a rery deep and remarkably narow gap in the white sandstone, and then into and through the Trias. For many miles it flows in a mere cleft barely fifty feet wide at the bottom and sometimes narower, and attaining a depth of more than 2,500 feet. In scouring down its channel into the sandstones the stream did not cut alwalys vertically, but swayed from side to side, so that now great bulges of the wall overhang the bot. tom of the abyss, and in some plices shut out the sliy orerhead. The Mnkíntuweap, or Little Zion fork, is even more remarliable. For a conriderable distance this stream also rms in a profonnd and exceptionally narrow chasm, but it at length widens out, and just where it joins the Parńnuweap is a scene which must ultimately become, when the knowledge of it is spread, one of the most admired in the world. Of this hereaficr. Below the junction of the forks the Virgen flows westward, and passes ont of the terraces and ont of the Platean Plovince. At length it joins the Colorado.

East of the drainage area of the Virenen is that of Kamb Creek. It heads in the broad ralley of Upper Kanab, whieh occupies an in. dentation of the southern margin of the Iligh Plateaus between tho Markígnnt and Paunsigunt. The bulk of the drainage passes throngh the upper cañon of Kamab Creek, and at length emerges upon the desert to the sonthward. linther on it sinks another chasm in the Carboniferous, which becomes a mighty side gorge of the Colorado, and unites with the Grand Cañon in the middle of the Kamab division.

Still eastwarl is the great amplnitheater which gires rise to the branches of the Paria. This stream flows sol theastward and nltimately enter's the Colorado at the head of the Marble Cañon.

In these three subordinate drainage basins of the terraces it is well to notice some features of importanee, common more or less to all, but most distinctly seen in Kanab Creek. 'They all rum contrary to the dip of the strata. The summits of the terraces dip to the northward, while the streams run southward. 'They thus form each a chain of cañons. 'Thus, Kanab Creek with its upper tributaries flowing in open valleys soon begins to ent into the Jurassic, and its gorge, ever deepening, at length beeomes nearly a thousand fect in depth. Suddenly the cañon walls swing to right and left to form the mural front which terminates the Jurassie terrace, and the river, now at the summit of the Trias, is once more in open country; but only for a short distanee, for it soon begins to cnt into the Trias, forming a great eañon as before. The same proeess is repeated and the river flows ont of its 'Triassic cliasm into the open again, while its walls swing in either direction to form the terminal escarpment of the 'Triassie terrace.

The three streams just mentioned are not the only drainage channels in the terraces, though they are the principal ones, and sooner or later (i G A 
gather the greater part of the drainage. There are many cañons in the terraces, aud they all have the same relation to the cliffs and to the dips of the strata. They cut into the terraces and emerge from them at the bases of their several cliffs. All except the three first mentioned are dry, carrying no streams except spasmodic floods during heavy rains and the melting of the snows. Many of them are actually filling up, the floods being nnable to carry away all the sand and clay which the infrequent rains wasl into them.

It is through the dry and partially refilled chasms that we may easily descend from the High Plateaus to the Carboniferous platform of the Grand Cañon district. 'To stndy the 'Trias, we may best go to the little village of Kanab and prepare for a jomrney along the base of the Vermilion Clift's.

'THE 'TRAS.

Kanab village is situated under the eaves of the Vermilion Cliffs, in the jaws of the cañon of Kanab Creek. It has for several years been the base of operations of the surveying parties working in the Grand Cañon district, and is well located for the purpose. After dne preparation, we may leave the village, proceeding about twenty miles sonthwestward to the sonthernmost promontory of the Triassic escarpment. Here is Pipe Spring, famons in this far-off region as a watering place. The reader would do well to find the locality on the map, for it is a notable point. The Vermilion Cliffs here change their trend to the northwestward, and we shall presently follow them to admire their beauty and magnitude; but before doing so it is well to take a brief view of their geologienl relations.

The Trias is in most places separated from the Jura by a purely pro. visional horizon which marks a change in the lithological aspect of the strata, and in the grouping and liabit of the series. Sometimes the passage from one to the other is obscured, but more frequeutly it is abrupt. The Jurassic sandstone is withont a likeness in any other formation, and the sandstones of the Trias can ordinarily be distinguished from it miles away. One of the most conspicuous distinctions is the color, and it is a never-failing distinction. The Jnrassic is white; the Trias is flam. ing red. Equally conspicuous is the difference in bedding and in the architecture. The Jura is a solid indivisible mass of 800 to 1,000 feet in trickness; the Trias is composed of a very great number of beds, most of which are only a few feet in thickness. One bed, however, attains vast proportions. The majority of the layers are eommon sandstones, and they predominate inost in the upper portion of the series. In the middle part the sandstones still predominate but are individually thinner, and are more often separated by shaly layers and by bands of gypsum. In the lower portions, sandy and argillaceous shales of won- 


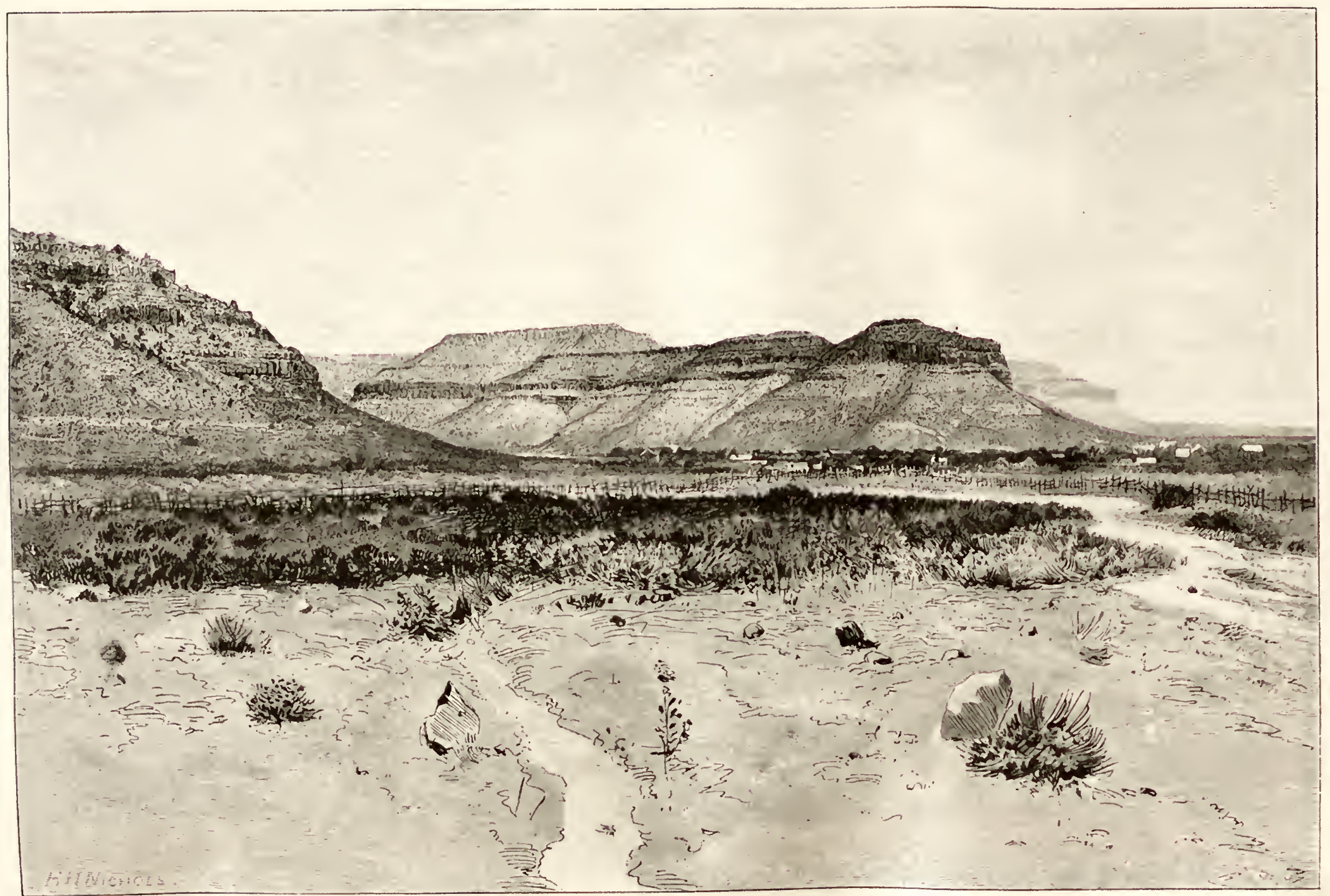

VIRMILLION CIIFIS AT KANAB. TRIASSIC. 
derful colors predominate. Line is found in these rocks, and in notable quantity, but it is almost always in the form of gypsum or selenite. To fossils in these parts liave yet been found which are of paleontological value; but fish-scales, and fiagments of bons scutes are sometimes obtained, which are useless for the purposes of the geologist. In the lower shales we fund a great abundance of fossil trces completely silicified and several bulky layers are composed rery largely of their fragments.

The Trias inakes its appearance upon the ontermost western flank of the Markágunt, a little north of the Mormon town Cedar, rising ly a fault out of the valley allurium. With a constantly expanding exposure, it extends southward aloug the west flank of the Markágunt and along the upthrow of the Hurricune fault, mitil the whole of its mass comes to the surface; then broadening out into a wide terrace, it swceps around the sonthwestern limit of the Colob and orcr into the valley of the Virgen, where it brcaks into chifs, temples, towers, and buttes of incffable splcullor and beauty. Thence, with a still wider terrace, bounded by a giant wall, it stretcles to the southeast as far as Pipe Spring. Here is its sonthermmost promontory, from which its front trends away northcast and east in proportions diminished somewhat, but still imposing, as far as the Paria River. Thus far the distance is more than 120 miles, in which the sinnosities of the front are not reckoned. Throughout this entire sweep it presents to the southward a majestic wall richly sculp). tured and blazing with gorgeous colors. The cliff line is very tortuons, adrancing in promontories, with intervening bays and broad cañon valleys setting far back into the terrace, and resembling a long stretch of coast-line gashed with fiords. Perhaps also the contour of a maple-leaf may be a suggestive analogy. The altitudes of the cliffs are areatest in their western portions, for there we find greater thicliness of strata. 'They often exceed 2,000 feet, while in the portion extending from Pipe Spring to the Paria the altitule ranges from 1,000 to 1,400 feet.

'IHE VERMILION CLIFFS.

To this great wall, terminating the Triassic ternce and stretching from the Hurricane Ledge to the Paria, Powell has griven the mame of The Vermilion Cliffs. 'Their great altitude, the remarkable length of their line of frontage, the persistence with which their proportions are sustained throughout the entire interval, their ornate sculpture and rich coloring, miglit justify very exalted language of description. But to the southward, just where the desert surface dips down ward beneath the horizon, are those supreme walls of the Grand Cañon, which we must hereafter behold and vainly strive to describe; and however worthy of admiration the Vermilion Cliffs may be we must be frugal of adjectives, lest in the chapters to be written we find their force and meaning ex. 
hausted. They will be weak and vapid enough at best. Yet there are portions of the Vermilion Cliff's which in some respects lay hold of the sensibilities with a force not much less overwhelming than the majesty of the Grand Cañon; not in the sane way, not by virtue of the same elenents of power and impressiveness, but in a way of their own and by attributes of their own. In mass and grandeur and in the extent of the display there is no comparison; it wonld be like comparing at private picture gallery containing a few priceless treasures with the wealth of art in the Vatican or Lourre. All of the really superlative portions of the Vermilion Clifr's could be eomfortably displayed in any one of half a dozen amphitheaters opening into the Kaibab division of the Grand Cañon. These portions ocenr in the beantiful valley of the Virgen, and they, as well as the features which characterize the entire front of the Vermilion Cliffs, merit some attempt at description.

Each of the greater sedimentary groups of the terraces from the Eocene to the Pernian inclusive, has its own style of sentpture and architecture; and it is at first surprising and always pleasing to observe how strongly the several styles contrast with each other. The elephantine structures of the Nile, the Greciau tenrples, the pagodas of China, the cathedrals of Western Europe, do not offer stronger contrasts than those we sucessively encounter as we descend the great stairway which leads down from the High Plateans. As we pass from one terrace to another the seene is wholly changed; not only in the bolder and grander urasses which dominate the landseape, bnt in every detail and accessory; in the tone of the color-masses, in the regetation, and in the spirit and subjective influences of the seenery. Of these many and strong antitheses, there is none stronger than that between the repose of the Jura and the animation of the Trias.

The profile of the Vernition Cliff's is very complex, though conform. ing to a definite type and made up of simple elements. Although it varies much in different localities it never loses its typical character. It consists of a series of vertical ledges rising tier above tier, story above story, with intervening slopes covered with talus through which the beds project their fretted edges. The stratification is always revealed with perfect distinctness and is even emphasized by the peculiar weathering. The beds are very mumerous and mostly of small or moderate thickness, and the partings of the sandstones include layers of gypsum or gypsiferous sand and slate. The weathering attacks these gypseous layer's with great effect, dissolving them to a considerable depth into the wall-face, producing a deeply engraved line between the inchuding sandstones. This line is always in deep shadow and throws into strong relief the bright edges of the strata in the roek-face, separating them from each other with uncommon distinctuess. Where the profiles are thrown well into view the rertical li.les, which bound the faces of the ledges, are quite perpendieular and straight, while the lines of the intervening slopes are feebly concave, being, in fact, descending 
branches of hyperbolas. 'They are graceful in form and indeed gemuine lines of beauty. The angles where the straight and curved lines meet, at the bases and summits of the ledges, are very lieen and well cnt. The composite effect thns given by the mnltiple cliffs and sloping watertables rising story above story, by the acute definition of the profiles and horizontal moldings, and by the refined though mobtrusive details, is highly architectural and ornate, and contrasts in the extrene with the rough, eraggy, beetling aspect of the cliff's of other regions. This effect is much enhanced by the manner in which the wall advances in promontories or recedes in alcoves, and by the wings and gables with sharp corners and Mansard roofs jutting out from erery lateral face where there is the least danger of blanliness or monotony. In many places cañons have cut the terrace platform deeply, and open in magnificent gateways upon the broad desert plain in front. We look into them from afar, wonderingly and questioniugly, with a fancy pleased to follow their windings mintil their sudden tmrns carry them into distant, unseen depths.

Northwestward of the southermmost promontory at Pipe Spring, the cliffs steadily increase in grandenr and animation, and also assmme new features. Near the summit of the series is a very heary stratum of sandstone, which is everywhere distingmishable from the others. This nember is seen at Kanab with a thicliness of about 200 feet. It increases westward, becoming 400 feet at Pipe Spring. Beyond that it still increases, reaching a thichness of more than 1,200 feet in the valley of the Virgen. It lias many strong features, and yet they elnde description. One point, lowever, may be seized upon, and that is, a series of joints nearly rertical with which the mass is everywhere riven. The fissures thins produced liave been slowly enlarged by weathering, and down the face of every escarpment rm the dark shadows of these rifts. TMey reach often from top to bottom of the mass and penetrate deeply its recesses. Wherever this great member forms the entablature-and west of Pipe Spring it nsnally does so-its crest is meren and presents towers and buttresses produced by the widening of these cracks. Near Short Creek it breaks into lofty truncated towers of great beauty and grandeur, with strongly emphasized vertical lines and decorations, suggestive of cathedral architecture on a colossal scale. Still loftier and more ornate become the structmres as we approach the Virgen. At length they reach the sublime. The altitudes increase until they approach 2,000 feet above the plain. The wall is recessed with large amplnitheaters, buttressed with linge spmrs and decorated with towers and pinnacles. Here, too, for the first time, along their westward trend, the Vermilion Cliffs send off buttes. And giant buttes they verily are, rearing their unassailable summits into the domain of the clouds, rich with the aspiring forms of Gothic type, and flinging back in red and purple the intense smuliglit ponred over them. Conld the imagination blanch those colors, it might compare them with vast. 


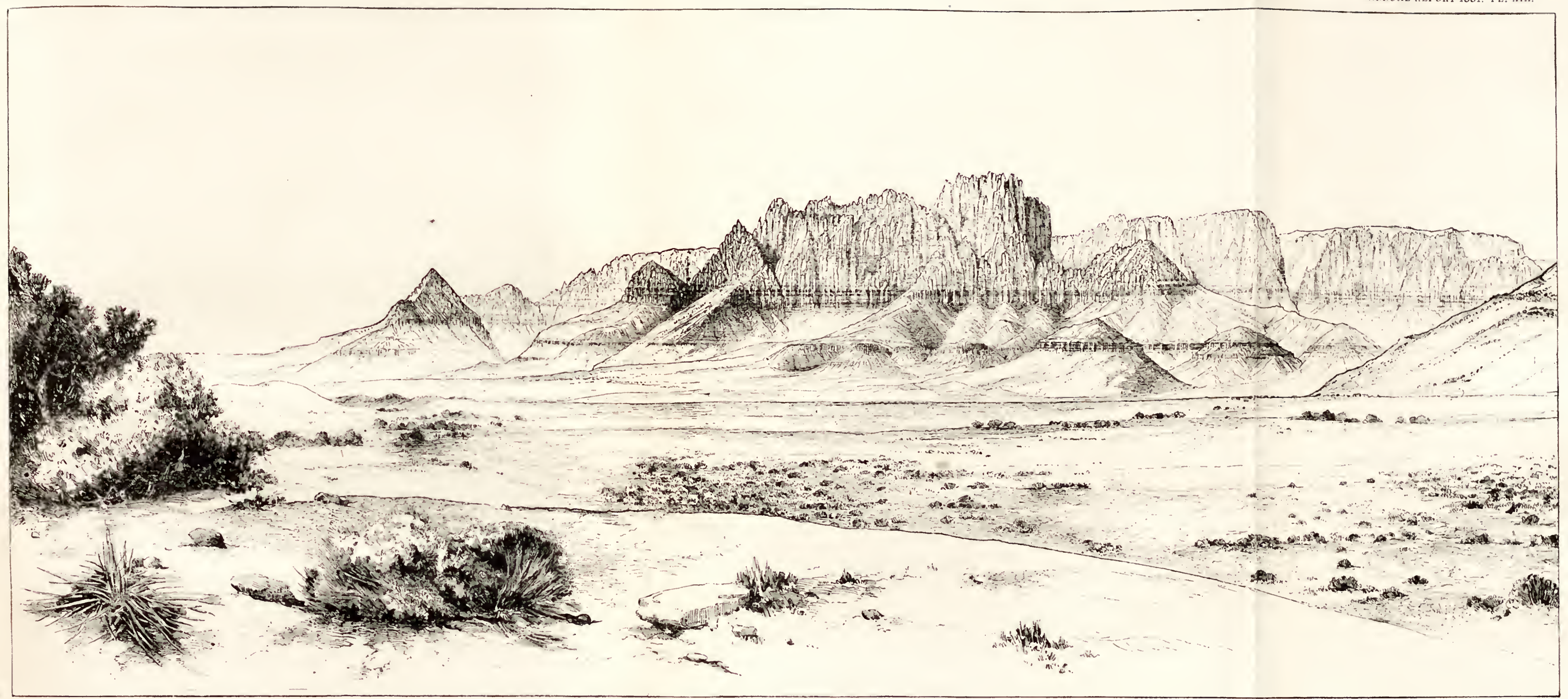


icebergs, rent from the front of a glacier and floating mijestically ont to sea; only here it is the parent mass that recedes, nrelting away throngh the ages, while its off-spring stands still. Yet the analogy wonld be a fecble one, for the buttes are grander, more definite in form, and many times loftier. Bnt the climax of this scenery is still beyourl.

Late in the antmmn of 1850 I rode along the base of the Vermilion Clift's, from Kanab to the Virgen, having the esteemed companionship of Mr. Hohmes. We lrad spent the summer and most of the antumm anong the eones of the Uinkaret, in the dreamy parks and forests of the Kaibab, and in the solitudes of the intervening desert; and onr sensibilities had been somewhat overtasked by the seenery of the Grand Cañon. It seemed to us that all grandenr and beanty thereafter beheld must be mentally projeeted against the reeolleetion of those seenes, and be dwarfed into commonplaee by the comparison; but as we moved onward the walls inereased in altitnde, in animation, and in power. At length the towers of Short Creek burst into view, and, beyond, the great eliff in long perspective thrusting ont into the desert plain its gables and spurs. The day was a rare one for this region. The mild, subtropieal autumn was over, and just giving plaee to the first approaches of winter. A sullen storm had been gathering from the sonthwest, and the first rain for many months was falling, ningled with snow. Heary elouds rolled mp against the battlements, spreading their fleeces over turret and erest, and sending down enrling fleeks of white mist into the nooks and reeesses between towers and buttresses. The next day was rarer still, with sunshine and storm battling for the mastery. Rolling masses of cumnli rose up into the blue to incomprehensible heights, their flanks and summits gleaming with sunlight, their nether surfices above the desert as flat as a eeiling, aud showing, not the dull nentral gray of the east, but a rosy tinge eanght from the refleeted red of rocks and soil. As they drifted rapidly against the great barrier, the currents from below, flmig mpward to the summits, rolled the raporons masses into vast whorls, wrapping them aronnd the towers and erest-lines, and scattering torn shreds of mist along the roek-faces. As the day wore on the sunshine gained the advantage. From overhead the cloud. masses stubbornly withdrew, leaving a few broken ranks to maintain a feeble resistanee. But far in the northwest, over the Colob, they rallied their blaek forces for a more desperate struggle, and answered with defiant flashes of lightning the ineessant ponr of smin-shafts.

Superlative elond effects, common enongh in other eountries, are lamentably infrequent here; but, when they do eome, their value is beyond measure. During the long, hot summer days, when the sun is high, the phenomenal features of the seenery are robbed of most of their grandeur, and eannot or do not wholly reveal to the observer the realities which render them so instructive and interesting. There are few middle tones of light and shade. The effeets of foreshortening are 
excessive, almost beyond belief, and produce the strangest deceptions. Masses which are widlely separated seem to be superposed or continnons. Lines and surfaces, whicl extend towards ns at an acnte angle with the radins of vision, are warped aromed nutil they seem to cross it at a right angle. Grand fronts, which onght to show depth and varying distance. become flat and are troubled with false perspective. Proportions which are full of grace and meaning are distorted and belied. Dnring the midday hours the cliffs seem to wilt and droop as if retraeting their grandeur to hide it from the merciless radianee of the smn whose very efinlgence flonts them. Fven the eolors are ruined. The glaring face of the wall, where the light falls finll mpon it, wears a scorched, overbalied, discharged look; and where the dense black shadows are thrown-for there are no middle shades-the magieal haze of the lesert shines forth with a weird, metallic glow which has no color in it. But as the sun lleclines there eomes a reviral. 'The half-tones at length appear, bringing into relief the eomponent masses; the amphitheaters reeede into suggestive distances; the salients silently advance towards us; the distorted lines range themselves into true perspeetive; the deforned eurves come back to their proper sweep; the angles grow elean and sharp; and the whole eliff arouses from lethargy and erects itself in grandeur and power, as if conseions of its own majesty. Batek also come the eolors, and as the sun is about to sink they glow with an intense orange-vermilion that seems to be an intrinsic luster emanating from the rocks thenselses. But the great gala-days of the cliffs are those when sminshe and storm are waging an eren battle; when the massive banks of clonds send their white difinse light into the dark places and tone down the intense glare of the direct rays; when they roll orer the summits in stately procession. wrapping them in rapor and revealing cloud-girt masses here and the:e through wide rifts. Then the trutl appears and all deceptions are exposed. 'Their real grandenr', their true forms, and a just sense of their relations are at last fairly presented, so that the mind ean grasp them. And they are very grand-even subline. There is no need, as we look upon them, of funcy to heighten the picture, nor of netaphor to present it. The simple truth is quite enouglr. I never before had a realizing sense of a cliff 1,800 to 2,000 feet high. T think I have a definite and abicling one at present.

As we moved northward from Short Creek, we had frequent opportunities to adinire these eliffs and buttes, with the eonvietion that they were revealed to us in their real ungnitudes and in their trme relations. 'They awakened an enthusiasm more vivid than we had anticipated, and one whieh the reeolleetion of far grander seenes did not dispel. At length the trail deseended into a shallow basin where a low ledge of sandstones, immediately mpon the right, shnt them ont from view; bnt as we monnted the opposite rim a new scene, grander and more bean. tiful than before, suddenly broke npon us. The eliff again appeared, presenting the leavy sandstone nember in a sheer wall nearly a thon- 
sand feet high, with a steep tahs bencath it of eleven or twelve hundred feet more. Wide alcoves receded far baek into the mass, and in their depths the clouds floated. Long, sharp) spurs phunged swiftly down, thrusting their monstrous buttresses into the plain below, and sending up pinnaeles and towers along the knife elges. But the eontrolling objeet was a great butte which sprang into view inmediately before us, and which the salient of the wall had hitherto masked. Upon a perestal two miles long and a thousand feet high, richly decorated with horizontal moldings, rose four towers highly suggestive of cathedral arehitectnce. 'lheir altitnde above the plain was estimated at abont 1,800 feet. 'They were separated by vertical clefts made by the enlargenent of the joints, and many smaller clefts extending from the summits to the pedestal carved the turrets into tapering bnttresses, which gave a graceful aspiring effect with a remarkable definiteness to the forms. We named it Smithsonian Butte, and it was decided that a sketch slould be made of it; but in a few moments the plan was abandoned or forgotten. For over a noteh or saddle formed by a low isthmus which eomeeted the butte with the principal nesa there sailed slowly and majestically into view, as we rode along, a wonderful object. Deeply mored, we paused a noment to eontemplate it, and then abandoning the trail we rode rapidly towards the notch, beyond which it soon sank out of sight. In an hour's time we reached the erest of the isthmus, and in an instant there flashed before us a scene never to be forgotten. In coming time it will, I believe, take rank witl a very small nmmber of spectaeles each of which will, in its own way, be regarded as the most exquisite of its kind which the world discloses. The scene before us was

THE TEMPLES AND TOWERS OF THE VIRGEN.

At our feet the snrface drops down by cliff and talns 1,200 feet npon a broad and rugged plain cnt by narrow eañous. 'The slopes, the winding ledges, the bosses of projeeting roek, the naked, scanty soil, display colors which are trnly amazing. Choeolate, in aroon, purple, lavender, magenta, with broad bards of toned white, are laid in horizontal belts, strongly eontrasting with each other, and the ever-varying slope of the surface cuts across them eaprieiously, so that the sharply defined belts wind about like the contours of a map. From right to left across the further foregromnd of the picture stretehes the inner cañon of the Virgen, about 700 feet in depth, and here of eonsiderable width. Its bottom is for the most part unseen, but in one place is disclosed by a turu in its course, showing the vivid green of vegetation. Across the cañon, and rather more than a mile and a half beyond it, stands the eentral and comnanding objeet of the pieture, the western temple, rising 4,000 feet abore the river. Its glorious summit was the object we had seen an hour 
before, and now the matchless beauty and majesty of its vast mass was all hefore us. Yet it was only the centril object of a mighty throng of structures wrouglit up to the same exalted style, and filling up the entire panorama. Right opposite us are the two principal forks of the Virgen, the Parinuweap coming from the right or east, and the Mukintuweap or Little Zion Valley, descending towards us from the nortl.. 'The Parúnnweap is seen emerging on the extreme right through a stupendous ginteway and chasm in the Triassic terrace, nearly 3,000 feet in cleptl. The further wall of this eañon, at the opening of the gateway, quickly swings nortliward at a right angle and becomes the eastern wall of Little Zion Valley. As it sweeps down the Parúnuweap it brealis into great pediments, covered all over with the richest carving. The effect is much like that which the architect of the Milan Cathedral appears to have de. signed, though here it is vividly suggested rather than fully realizedas an artist painting in the "broad style" suggests many things without actually drawing them. The smmptuous, bewildering, may effeet is all there, but when we attempt to analyze it in detail it eludes ns. 'The flank of the wall receling up the Mnliuntuweap is for a mile or two sinilarly decorated, but soon brealis into new forms much more impressive and wonderful. A row of towers lialf a mile ligh is quarried out of the palisade, and stands well adranced from its face. 'There is an eloquence in their forms which stirs the inagination with a singular power, and kindles in the mind of the dullest observer a glowing response. Just behind them, and rising a thousand feet higher, is the eastern temple, crowned with a cylindric done of white sandstone; but since it is, in many respects, a repetition of the nearer western temple, we may turn our attention to the latter. Directly in front of us a complex group of white towers, springing from a central pile, mounts upwards to the clonds. Out of their midst, and high orer all, rises a dome-like mass, which dominates the entire landscape. It is almost pure white, with brilljant streaks of earmine descending its rertical walls. At the summit it is truncated, and a flat tablet is laid npon the top, slowing its elge of deep red. It is impossible to liken this object to any familiar shape, for it resembles none. Yet its shape is far from being indefinite; on the contrary, it has a definiteness and individnality which extort an exclamation of surprise when first beheld. There is no name provided for such an object, nor is it worth while to invent one. Call it a clome; not because it las the ordinary sliape of such a structure, but because it performs the function of a dome.

'The towers which surround it are of inferior mass and altitnde, but each of them is a study of fine form and architectural effect. They are white above, and change to a strong, rich red below. Dome and towers are planted npon a substructure no less admirable. Its plan is in. lefinite, but its profiles are perfectly systematic. A curtain wall 1,400 feet high descends vertically from the eaves of the temple and is suc. ceeded by a steep slope of ever-widening base courses leading down to 


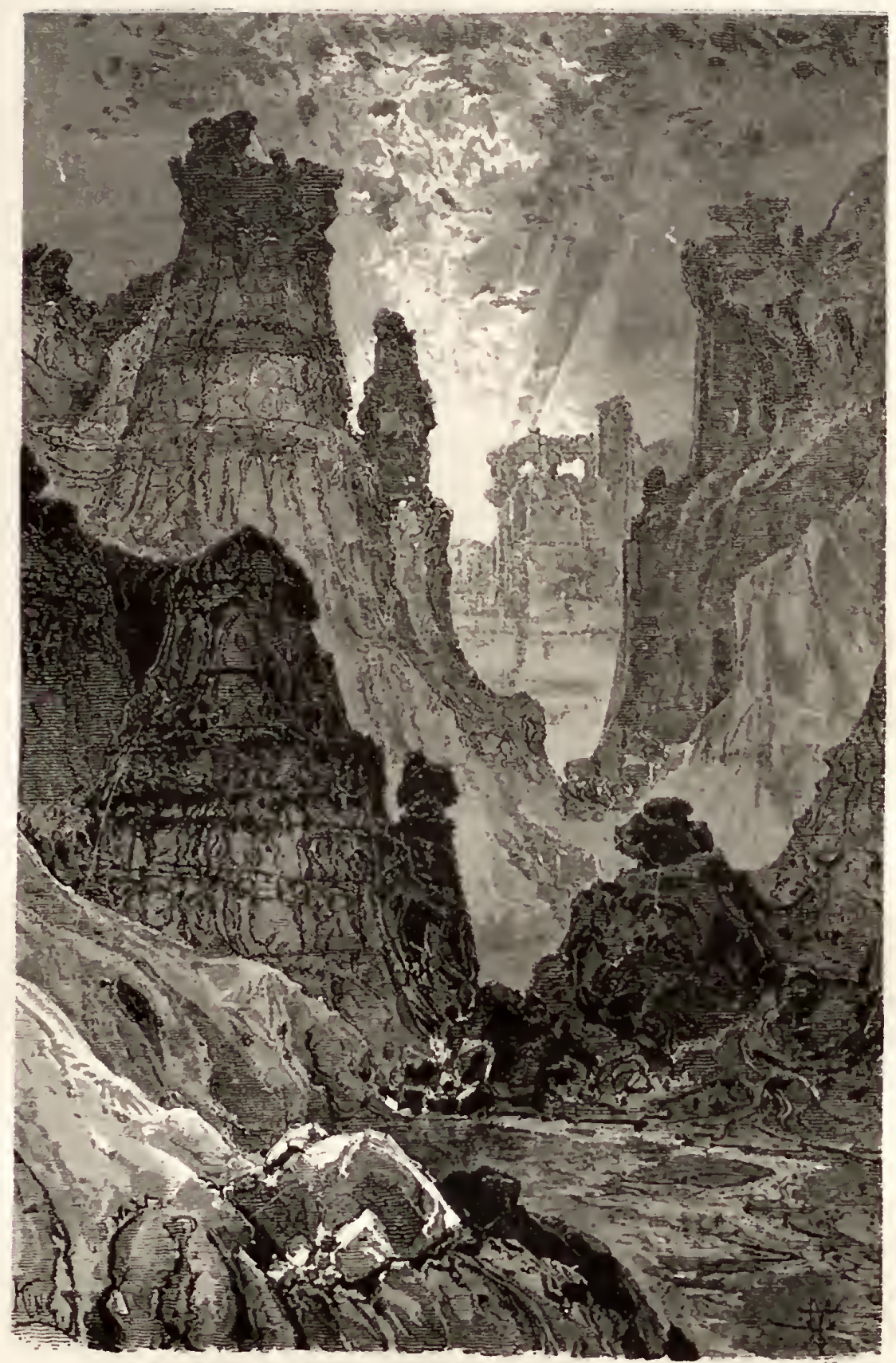

Fı. 6.-The MIn.kún-tu.weap.

the esplanade below. 'The curtain-wall is decorated with a lavish display of vertieal moldings, and the ridges, eaves and mitered angles are fretted with serrated cusps. This ornamentation is suggestive rather than precise, but it is none the less effective. It is repetitive, not symmetrical. But though exact symmetry is wanting, nature luas liere bronght home to us the truth that symmetry is only one of an infinite range of devices by which beauty can be materialized.

And tiner forms are in the quarry

Than ever Angelo eroked.

Reverting to the twin temple across Ijittle Zion Valley, its upper mass 

is a repetition of the one which crowns the western pile. It has the same elliptieal contour, and a similar red tablet above. In its effect upon the imagination it is much the same. Butfrom the point from which we first riewed them - and it is by far the best one aceessible-it was too distant to be seen to the fullest advantage, and the western temple by its greater proximity overpowered its neighbor.

Nothing can exceed the wondrous beanty of Little Zion Valley which separates the two temples and their respective groups of towers. Nor are these the only sublime structures which look down into its depths, for similar ones are seen on either hand along its receding vista until a turn in the course carries the valley ont of sight. In its proportions it is about equal to Yo Semite, but in the nobility and beanty of the sculptnres there is no comparison. It is Hyperion to a satyr. No wonder the fieree Mormon zealot, who named it, was reminded of the Great Zion, on which his fervid thoughts were bent-_ "of honses not built with hands, eternal in the heavens."

From these highly wrought groups in the center of the pieture the eye escapes to the westward along a mass of eliff's and buttes eovered with the same profuse decoration as the walls of the temples and of the Parunuweap. Their color is brilliant red. Much animation is imparted to this part of the scene by the wandering eourses of the mural fronts which have little continuity and no definite trend. The Triassic terrace out of which they have been carved is cut into by broad amphitheatres and slashed in all direetions by wide eañon valleys. The resulting escin'pments stretch their courses in every direction, here fronting towards in, there averted; now receding behind a nearer mass and again emerging from an museen alcove. Far to the westward, twenty miles away, is seen the last palisade lifting its imposing front behind a mass of towers and domes to an altitude of probably near 3,000 feet and with a grandenr which the distance cannot dispel. Beyond it the scenery changes almost instantly, for it passes at once into the Great Basin, which, to this region, is as another world.

'IIF: PERTI IN.

The idea of a terrace is not so typically represented in the Permian as it is in the superior formations. In many parts of the great stairway it clearly forms the lowest step; in others it forms one cliff with the Trias; in still others it is beveled off and covered with alluvium. On the whole it is more frequently presented as a distinct terrace. There is another qualification which requires some mention, because when we refer to the geological map to study the surface distribution of the strata, we should find some anomalies unless the point referred to were dnly explained.

Wherever we encounter a cliff which discloses the upper Permian beds we find at the summit of the escarpment a band of pale-brown 
sandstone of very coarse lexture, often beconing a conglomerate. Its thickness is usually from 40 to 75 feet. In a few places it is wanting from its proper horizon, and in some others its thickness becomes more than 100 feet. But on the whole it is a remarkably persistent bed, and its persistence is all the more striking when wo consider the coarseness of its texture; for no beds are so rariable as the coarse ones. 'This nember has been named by Powell the Shin-á-rump Conglonerate. The mame Shinarmmp he also applies provisionally to al large group of beds in which the conglomerate is included." For several years it was thought very probable that these beds were a part of the 'lriassic system, though no positive proof conld be eited to sustain that pre. snmption. In the summer of $1879 \mathrm{Mr}$. C. D. Walcott, of this survey, at length fonnd some limestone bands near the base of Powell's Shinarnmp, which seem to establish pretty conclusively their Permiau age. But the fossils so far discovered liave only a small vertical lauge, aud lie near the base of the group. Above them are many hundred feet of beds which yield no fossils at all. While some of them are unquestion. ably Permian, it still remains to find the horizon where the Permian euds and the Trias begins. The Trias is as destitute of fossils as the Permian, excepting, however, some which are useless for determining age. In eases like this the geologist finds himself in trouble. He is quite sure that he has beds of two distinct ages; and lie unust, for purposes of diseussion, separate them somehow; if not by a natural and unmistakable dividing horizon, then by an arbitrary and provisional one, subject to amendment by future research. But lie must look very carefully for a uatural horizon of separation. His course of procedure would be somewhat as follows. Starting, for instance, with those strata which he was sure were 'Triassic, he would examine the beds downwards and finding no fossils would pay attention to their lithologieal characters. Finding no marked difference in the beds, and finding a strict parallelism or "conformity" in the several members, he would infer that they were deposited under conditions which were substantially identical throughout the period of deposition. But if he at leugth reached a stratum of very different character, say, for instance, after passing down through a great series of sandstones and shales, he came to a heavy mass of limestone or a bulky conglomerate, he would hare found at last a "loreak" in the continuity or homogreneity of the group. Here, at last, is something which he can use. It may or it may not be synchronous with the dividing horizon used in Russia, England, or Kansas, but it is at all events not far from it; and it is something palpable, distinct, and recognizable by those who come after him. In this way Mr. Walcott

"For the information of the general reader it may bo explained that when thes geologist entering a new region diseovers a well-defined group of beds whieh either yield no fossils at all or yield sueh as do not enable him to determine conelusively the ago of the series, he does not assign tho beds to any definite ago or system, but gives them a purely provisional and loeal name which is dropped as soon as the true age is established. 


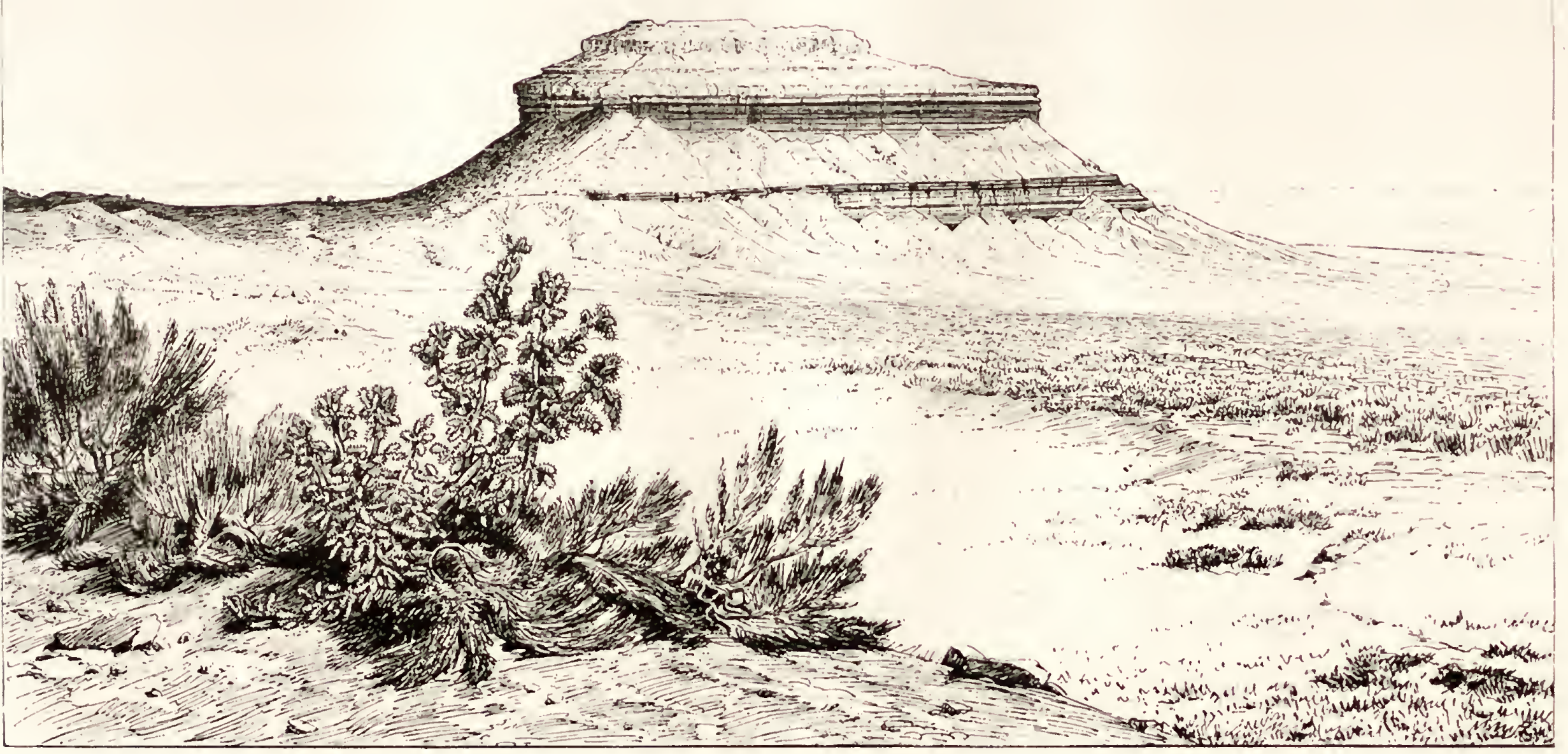


seized upon the Shinarump conglonerate as a divisional stratum betreen the Trias and Permian. Bnt another perplexing question arose. 'To which of the two series shonld the conglomerate itself be assigned? And the question is not at first an easy one to answer. Inmediately above it is a series of sandy shales sueh as beggar description on acconnt of their gorgeous colors. Immediately below it is another series of sandy shales so sinilar to the one above that we never know which of the two we are looking at muless the conglomerate is in sight as a "beneli-mark." Mr. Walcott settled the question (provisionally, of conrse) in the following way. The summit of the lower series slows in many places that immediately after it was deposited it was slightly eroded, and the contact of the conglomerate slows an "minconformity by erosion." "The contact of the conglomerate with the upper series shows no sneh unconformity. Now, an nuconformity means to the geologist a break in the continnity of deposition, and in the absence of reasons to the contrary, and with no better divisional criterion at hand, it may be used to separate two series of beds. He therefore assigned the conglomerate to the Trias, and the beds below he placed in the Permian.

Mr. Walcott's conclusion is 110 doubt the best which can be reached with our present linowledge, bnt it is rery inconvenient and aw kward to the geologist who is required to map) the distribution of the strata and their topographical features. In all of the other formations each group forms its own terrace or series of terraces. As we descend them we find omselves, when we reach the foot of the Eocene cliff, npon the smmmit of the Cretaceons. Reaching the foot of the Cretaceons clifis, or slopes, we are upon the broad expanse of the Jurassie platform. Deseculing the Jurassic, we find the 'Trias coming out from the base of the Jurassic Cliffs; but when we descenrl the Vermilion Cliffs, we have not reached the Permian. 'The Trias is still beneatlus, pushing ont its basal nenber, the Shinarmul, conglomerate, elear to the crest-line of the Perminn wall. In the Jurassic terrace and in its terminal eliff we find none bnt Jurassiestrata. Similarly, also, on the cliffs and terrace platforms of the Cretaceous and Eocene; but the Permian terrace is everywhere sheeted over with a solitary stratmu of the 'Trias. Somehow we cannot help thinking that the conglomerate has no business there, and that it ought to liave been ent off at the base of the Vermilion Cliffs, or else it onglit to be relegated to the Permian. In delineating the distribntion of the formations by means of color's on the map, the ordinary practice would require ns to extend the 'Trias to the brink of the Permian Clifts, for in such delineations we only profess to show the snrface exposures of the several gromps; but this wonld confound the Perminn terrace with the 'Trias, and obliterate the individuality of the former, whereas in the topography both are as clistinet as land.and water. To preserve this distinction the Shinarump is denoted by a special modification of the 


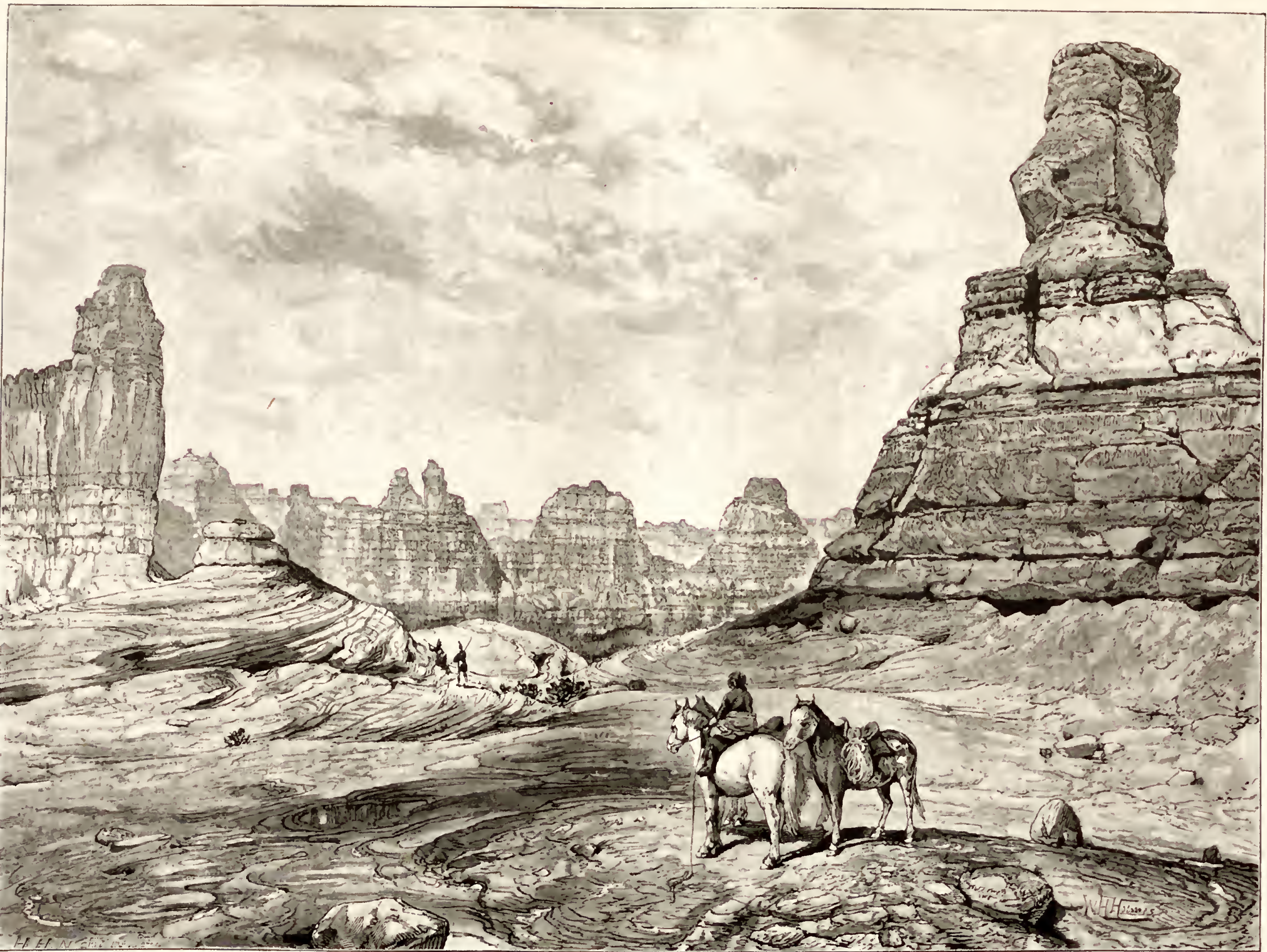

LAND OF TIE STANDING ROCKS. 
color, which is to be interpreted as meaning an arbitrury subdivision of the Trias.

The Permian beds consist of sandy clay-shales in very many thin beds and a few thin beds of impnre limestone. They are very striking on account of their dense, rich colors, which are sometimes also wonderfinly delicate. They are belted in a surprising way. Horizontal streaks of chocolate, purple and red-brown are interstratified with violet, lavender, and white. Perhaps the richest tone is the red-brown, which is almost exactly like the color of the fumes of nitrous acid. Lower in the series are layers of a very peculiar shade of Indian red, alternating with grayish white. In the lower Trias and Permian the colors reach their elimax. Snrely no other region in the world, of which I have any knowledge, can exlubit anything comparable to it. Wonderfully even is the bedding. Thin layers may be traced for miles without showing any rariation of thickness, color, or texture. In the escarpments the weathering has etched ont the harder layers, leaving a line of shadow in the places of the softer layers, and this greatly emphasizes the stratification and gives it finer detail.

The Permian series is of considerable magnitude. In the western portion of the district its thickness is greater than elsewhere, reaching, probably, 1,400 feet, and possibly 1,600 feet, while in the ricinity of Kamab it is less than 1,000 feet. It gives rise to terminal cliffs, which in the northern part of the Uinkaret are from 800 to 1,000 feet high, while around Kanab their height seldom exceeds 500 or 600 , and is often less than 300. But what they lack in magnitude they make up in refine. ment and beauty of detail and in sumptuous color. It is in the Pernian that we find the most remarkable buttes. They are never large, but their resemblances to human architecture or works of design are often amazing. Very few Permian buttes are found in the Grand Cañon distriet, but further eastward, especially in the neighborhood of the junction of the Grand and Green Rivers, they are inmumerable and of such definiteness that the geologist feels as if he were taxing the crednlity of his hearers when he asks them to believe that they are the works of nature alone, and not of some race of Titans.

At the foot of the Permian cliffs begins the Carboniferous platform of the interior region of the Grand Cañon district. It stretches southward without visible bonnd, an almost featureless plain. It terminates be. yond the San Francisco Mountains in the Aubrey Clift's. 


\section{H A P T E R I V.}

\section{'TIIE GREAT DENUDATION.}

Before leaving the terraces we may with advantage pause to contemplate the great lesson in geology which they lay open to ns. The subject of the lesson is Erosion. In a preliminary way we examined the type of it in the San Rafacl district, which was briefly treated of in the first chapter. The same fact confronts $n$ s again in the Grancl Cañon district. Here, howerer, the attendant facts are more complex, nore difficult to grasp, and less easy to summarize. And vast as the erosion has been in the San Rafael it has been many times greater in the Grond Cañon district. In this discussion three classes of facts will be ntilized: 1 st, the stratification; 2d, the faults and flexures, or vertical displace. ments; 31, the drainage. Each elass furnishes its quota of evidence. Yet, so intimately are the several threads of argument interwoven, that it is almost impossible to separate them and view each independently of the others. Hence if the argunent skips about from one to another before the one is fully developed, it is becanse no other method of treatment seems practicable.

The geologist seeing the series of Mesozoic and Hocene strata surldenly terminating in the terraces in the faces of the clifris, would at once say that these strata formerly extended further sonthward. For he is ever mindful of the fact that in the lapse of long periods the rocks lecay, and the rains and rills gather up the débris and carry it away. lle also has had impressed upon his mind the general fact that the most lappid waste takes place on the edges of the strata exposed iu vertical wall-faces. Every year the rains wash away something from the mural fronts. In a single year it may be a mere film, but in the lapse of thousands of centuries the anount whittled off becomes a vast aggregate. like the motion of the fixed stars the change is not perceptible to a generation; but a million years would change the aspect of a denuding conntry as profoundly as they would change the aspect of the hearens. How long in terms of years this "Recession of the Cliff's" has been going on, the geologist does not know, though he presumes the period to have been certainly lnmdreds of thousands of years and very probably some millions. Feeling assured, then, that the terraces once projected further south, the inquiry arises, how fan? Let me answer at once. They extended sonthward over the entire Grand Cañon district, into centr"il Arizona, where they ended along the shore of the ancient mainland 
from which their materials were in part derived. 'Ille distance of that shore-line, from the snmmit of the Pink Cliffs, is firm 130 to 180 miles, and the width of the dennded distriet is from 120 to 140 miles. From the base of the Vermilion Cliff's the distance is 25 to 30 miles less. The area of maximun demudation is from 13,000 to 15,000 square miles, and the arerage thiekness of the strata remored from it was abont 10,000 feet.

The general reader will no doubt feel a strong arersion to snch prodigions figures on their first presentation, and even the geologist whose eredulity has been sloeked so often that he has gotten used to it niay winee onee more. It is not from a love of the marelous or dramatic; it is not withont a full sense of the oppression of maceustomed magnitudes that these assertions are made. They me nude beeause they follow inexorably from the fiuts, and because they are neeessary conclnsions from clear premises. Bnt, in order that the reader nay not be obliged to earry a heavy burden of prejudice as he follows the various steps of the argument, it is well to anticipate some part of the diseussion, and thus relieve him of a great part of the load at the outset, for it can be shown that the figures, while they are eertainly very large, are in no respeet abmornal, and in only one respeet are they at all musnal.

Erosion, viewed in one way, is the supplement of the process by which strata are acemmulated. The naterials which constitute the stratified roeks were derived from the degradation of the land. This proposition is fundamental in geology-nay, it is the broadest and most compreliensive proposition with which that seience deals. It is to geology what the law of gravitation is to astronomy. We ean conceive no other origin for the materials of the strata, and no other is needed, for this one is sufficient and its verity a thousand times proven. Erosion and "sedimentation" are the two half phases of one eycle of causation-the debit and eredit sides of one system of transaetions. The quantity of material which the agents of erosion deal with is in the long rmu exactly the same as the quantity dealt with by the agencies of deposition; or, rather, the materials thus spoken of are one and the same. If, then, we would know how great have been the quantities of material removed in any given geological age from the land by erosion, we have only to estimate the mass of the strata deposited in that age. Constrained by this reasoning, the mind has no escape from the conchusion that the effects of erosion have indeed been rast. If, then, these operations liare achiered sueh results, our wonder is transferred to the immensity of the periods of time required to aceomplish them; for the processes are so slow that the span of a life-time seems tou small to reuder those resnlis directly visible. As we stand before the terrace eliffs and try to conceive of them receding seores of miles by seenlar waste, we find the endearor quite nseless. 'There is, however, one error against whieh we must guard ourselves. We must not eonceive of erosion as merely sapping the fice of a straight serried wall a hundred miles long; the locus of the wall 
receling parallel to its former position at the rate of a foot or a few feet in a thousand years; the terrace back of its crest line remaining solid and uncut; the beds thus dissolving edgewise nutil after the lapse of millions of eenturies their terminal eliffs stand a linndred miles or more back of their initial positions. The trine story is told by the Triassic terrace ending in the Vermilion Clifts. This terrace is literally sawed to pieces with eañons. There are dozens of these eliasus opening at intervals of two or three miles along the front of the esearpment and setting firr back into its mass. Every one of them ramifies again and agin mutil they become an intricate net-work, like the fibers of a leaf. Wvery cañon wall, througlont its trmuk, branches, and twigs, and every aleove and niche, becomes a dissolving face. 'Thus the lines and area of attack are enormonsly multiplied. The front wall of the terrace is ent into promontories and bays. The interlacing of banch cañons back of the wall ents off the promontories into detacied bnttes, and the bnttes, attacked on all sides, nolder away. The rate of recession therefore is correspondingly accelerated in its total effect.

The largeness of the area presents really no difficulty. The forees which break up the rocks are of meteorie origin. The agency which earries off the débris is the water rmming in the drainage channels. Snly" the meteoric forees which ravage the roeks of a township may ravage equally the rocks of the county or state, provided only the conditions are uniform over the larger and smaller areas. And what is the linit to the length of a stream, the number of its brancles and rills, and to the quantity of water it may cary? It is not the area, then, which op. presses us by its magnitnde, bnt the vertical factor-the thicliness of the mass remored. Bnt upon eloser inspeetion the aspect of this factor also will cease to be forbidding.

For if the rate of recession of a wall fifty feet ligh is one foot in a given nmmber of years, what will be (ceteris paribus) the rate of reeession in a wall a thonsand feet high? Very plainly the rate will be the same.* If we suppose two walls of equal length, composed of the same lind of rocks, and situated under the same elimate, but one of them mneh higher than the other, it is obvious that the areas of wall-face will be proportional to their altitndes. In order that the rates of recession may be equal, the amount of material removed from the ligher one must be donble that removed from the other, and since the forees operating on the higher one. have twice the area of attack, they onght to remove from it a double qnantity, thus making the rates of reeession equal. In the same way it

* The geologist will no donbt recognizo that this is a simple and unqualified statement of a result which is in reality very eomplex, and sometimes requiring qualifieation. But a eandid review of it in the light of established laws groverning erosion will, I am eonfident, justify it for all purposes here eontemplated. 'Though some qualifying conditions will appear when the subjeet is analyzed thoroughly, they are of no applieation to this partieular stilge of the argument. The statement is amply true for the proposition in hand, and it would he hardly practicable, and certainly very prolix, to give here the full amalysis of $i t$. 
may be shown that the rate of reeession is substantially independent of the magnitnde of the eliff, whatever its altitude. Here a momentary digression is necessary.

We have hitherto spoken of the reeession of eliff's as if it comprised the whole proeess of erosion, and have hardly alluded to the possible degradation of the flat surfaces of plateans, terraees, and plains. Is it meant that there is no degradation of the liorizontal surfices, and that the waste of the land is wholly wronght by the decay of clifts? Approximately that is the meaning, but some greater precision may be given to the statement.

Erosion is the resnlt of two complex groups of proeesses. The first group comprises those whieh aecomplish the disintegration of the roeks, redneing them to fragments, pebbles, sand, and elay. The second conprises those processes which remove the débris and eary it alwy to another part of the world. The first is called disintegration; the second, transportation. We need not attempt to study these processes in all their seope and relations, but we may advert only to those considerations which are of immediate eoncern. When the débris prodnced by the disintegration of rocks is left to acemmlate mpon a flat smrfiee it forms a proteeting mantle to the roeks beneath, and the disintegration is greatly retarded, or eren wholly stopyed. In order that disintegration may go on rapidly the débris must be earried away as lapidly as it forms. But the efficiency of transportation depends upon the declivity. 'The greater' the slope the greater the power of water to transport. When the slope is greater than $30^{\circ}$ to $: 33^{\circ}$ ("the angle of repose") loose matter eannot lie upon the roeks, and shoots down until it finds a resting place. Hence the greater the slope the more fully are the rocks exposed to the disintegrating forees, and the more rapidly do they decay. This relation is miversal, applying to all countries, and explaius how it comes abont that the attack of erosion is highly eflective against the chiff's and steep) slopes, and has but a trifling effect npon flat sulfices.

Reverting to the main argnment, it now appears that erosion goes on by the deeay and removal of material from eliffs and slopes; that the reeession of high cliffs is as rapid as the recession of low ones, and that the quantity of naterial removed in a given time increases with the al. titudes of the cliffs and slopes. In other words, the thiekness of the strata removed in a given period of erosion shonld be proportional to the amount of -relief in the profiles of the eomntry. But in the Platean country, and especially in the Grand Cañon district, these reliefs aro very great. It is a region of giant eliffs and profound eañons, and, as will nltimately appear, it has been so during a very long streteh of geological time. The thiekness of the strata removed from it is only proportional to the vahnes of those eonditions which favor rapid erosion. In the fore. going disenssion it may appear that the area of denndation in the Grand Cañon district, though large, and the thickness of the strata dennded, 
thongh very great, are not so excessive as to impose such a heary burden upon the crednlity as the first announcement of the fignres portended.

In drawing inferences from the stratification the geologist is obviously bound to presune that the strata cut off in the terraces extended originally without a break until they reached some locality where the conditions of deposition failed. There are two, and only two, cases to be considered. The first case is that in whieh the extension is towards the shore line of the sea or lake in which the strata were deposited. At the shore line the strata, of course, end. In the present case no shore line cond have existed son thward, between the terraces and the Anbrey Cliffs, beyond the San Franciseo Momntains. This is quite certain. We know the conntry sowell that if there had been such a shore line in this interval its traces would have been discovered. We are quite sure that no sueh traces exist. The second casearises when sediments gradually thin ont seawards and either vanish entirely or become so thin that their bulk is only nominal. We have alleady noted that the strata in the terraces (p. 79) grow thinner from west to east, and we know that the shore line of the marine basin, in which they were deposited, lay to the west and northwest. But here we are considering their extensions towards the south, and we already linow that more than one hundred miles in that direction was another part of the shore line surrounding the basin trending nortlrwest and sontheast. Supposing strata to attenuate as they recede from, and to thicken as they approach, their shore lines, the case we are considering would perhaps be about as follows. Sonthward as fir as the Grand Cañon, $i$. $e$., half way or thereabout between the terraces and the sonthern shore, there might be some slight reason for inferring a very little attennation, but beyond the Grand Cañon wo might with equal reason infer a thickening. But this reasoning is obviously precarious, since the attemation of strata as they approach or recede fro min shore lines does not follow any rigorous law-does not conform to any definite proportion. The best and apparently the only use we can make of it is rather of a negative character, leading us to infer merely that the stratification does not ofler any reason for presuming that their original sonthward extensions were notably thinner than the portions preserved in the terraces. But there is another class of facts which is somewhat more to the purpose.

Of the demnded formations, some ontliers are preserved at a considerable distance from the terraces. In the case of the Permian there is no doubt. The great Carboniferous platform of the Grand Cañon district is spotted in many platees with Permian remnants, though rarely is the whole series preserved. One important remnant shows very nearly the whole series-at Mount Logan, in the Uinkaret Platean, near the Grand Cañon. A conspicnous knoll, called the Red Butte, sontl of the Kaibab and abont 30 miles from the San Franciseo Monntains, also preserves a large part of the series, and innumerable patches of lower Permian beds are found on both sides of the great chasm. They show no attenuation 
whaterer, and indeed the Mount Logan mass is one of the thickest expo. sures of Pernian beds thus far discorered. The former extension of this series orer the entire district in full rolmme may therefore be re. garded as proven. In the case of the 'Trias the evidence is from this point of view not quite so elear. South of the Vermilion Cliff's two or three remunts of it have been seen. One lies in the Grand Wash, a lateral valley joining the Colorado from the north just where it issues firom the lower end of the Grand Cañon. Another has been recognized by Mr. Gilbert mnder the protection of lavas in the gigantic pile of San Franciseo Monntain. But in neither of them is the entire 'Triassic: series represented. 'These may be held to prove also the extension of the 'Trias over the entire distriet, and they give no sign of any attenna. tion in the beds preserved. But of the Jura and Cretaceous not a solitam ontlier has yet been detected at any considerable distance from their prineipal teraces. As to these two later formations we can only reason from general eonsiderations. The Jura and Trias, wherever found, appear to be merely different portions of one period of deposition; the physical conditions attending the acemmution of both appear to have been almost identical. Nor have we any reason to doubt that the same considerations apply to the Cretaceons and Eocene.

Still more foreibly is the same conclision presented to us when we come to the sturly of the fanlts and flexures. 'The Grand Cañon district, the High Plateans, and indeed the entire Plateau conntry, has been hoisted during Tertiary time far above the Sierra region lying west of it. At the western border of the plateans are fomd gigantic faults where the strata have been sheared, and the comntry on the eastern side presents beds lying thonsands of feet higher than the contima. tions of the same strata on the western side of the fanlts. 'These fanlts have been studied, and the amounts of the displacements are very alpproximately lnown. Owing to the remarkably clenr mamer in which all the facts are displayed, we are able, theoreticilly, to restore the country to the position and configmation existing before these beds were fanlted and flexed. In this treatise, only the results can be given. The diseussion and treatment of the problem is too purely technieal for popular explanation. 'This restoration, so far as it has progressed, shows, without reasonable doubt, that throughout Mesozoic time, and very probably during a part of 'Tertiary time, the Carboniferous and Permian strata of the Grand Cañon district were horizontal and mbroken, the greatest possible discrepancies being very small. Thus another and important point is gained, for it supponts the conchision that the eonfiguration of the Mesozoic sea-bottom, as well as its relations to the adjoining coasts, was, in the midlle and sonthern portions of the Grand Cañon district, farorable to the reception of the same mass of sediments as we now find in the terraces of the High Plateans.

'The argument from the drainage system is, in principle, the same as that applied to the San Rafael Swell, though different in details. The 
Golorado River and its tributaries entering the Grand Cañon had their origin at the time the conntry emerged from the waters aud became land. This was in early Tertiary time. The rivers then must have had their courses laid out in conformity with the very feeble slopes of the newly risen conntry and in conformity with the surfaces of the newest strata. In the progress of 'Tertial'y time this surface, originally as level as the prairies of Illimois, or more so, began to deform by unequal mp). lifting; but the riv.rs remained unchanged, and some of them are flowing to-day along the same routes as of old. Others have dried up, and the very strata which contained their troughs have been swept away. Those which remain occupy a very different relation to the strata from that which they held at first. The tributaries on the north side now run against the dips; those on the south side run with the dips, or nearly so. But the change has been in the attitudes of the strata and not in the positions of the rivers. And if we theoretically reconstruct the attitudes of the strata to conform to the conses of the drainage channels we reach a reconstruction exactly the sane as that which we deduced from a restoration of the faults and flexures.

Thns the stratification, the outliers, the faults and flexures, and the drainage all yield their quotas of testimony to the great fact of denudation, and indicate that at some initial epoch the whole Mesozoic system and the lower Eocene once extended over the entire platform of the Grand Cañon district, with a thickness varying somewhat, no doubt, but on the whole differing but little, from that which we now find in the terraces of the High Plateaus. It is to be noted that the evalence of this former extension is more complete in the ofder formations than in the younger ones. In the case of the Permian it is quite perfect; in the case of the 'Trias very nearly so; in the case of the Jura it is very little less cogent than in that of the 'Trias; and in the Cretaceons practical certainty is exchanged for a very high degree of probability barely distingnishable from certainty. In the case of the Eocene there still remains a strong probability, but there is room for reservation. No reason to the contrary can be shown at present, and it may be regarded as one of those cases where "the tail goes with the hide"; but we cannot promise that future rescarch will not develop reasons for a different conclusion. As the evidence now stands we are impelled to accept the full extension of the Eocene with some reservations, arising not from conflicting evidence, but from want of perfection in the evidence known to ns.

BASL LEVELS OF HROSION.

In his popular nanative of Explorations of the Colorado River: Powell has cmployed the above term to give precision to an idea which is of much importance in physical geology. The idea in some form or other 
has, no doubt, oceurred to many geologists, but, so far as known to me, it had not before received suel definite treatment nor been so finlly and justly emplasized. It may be explained as follows.

Whenever a smooth eomitry lies at an altitude but little above the level of the sea, erosion proceeds at a rate so slow as to be merely nomi. nal. The rivers cannot eorrade their ehannels. Their dechivities aro very small, the relocities of their waters very feeble, and their transporting power is so much reduced that they ean do no more than urece along the detritus brought into their troughs from highlands around their margins. Their transporting power is just equal to the load they have to carry, and there is no surplus left to wear away their bottoms. All that erosion ean now do is to slowly carry off the soil formed on the slopes of mounds, banks, and hilloeks, which faintly diversify the broad smroming expanse. The erosion is at its base-level or very nearly so. An extreme ease is the State of Florida. All regions are tending to base-levels of erosion, and if the time be long enough each region will, in its turn, approach nearer and nearer, and at last sensibly reach it. 'The approaeh, however, consists in an infuite series of ap. proximations like the approach of a liyperbola to tangeney with its asymptote. 'Thus far, however, there is the implied assumption that the region undergoes no clange of altitnde with referenee to sea-level; that it is neither elerated nor depressed by subterranean forees. Many regions do remain withont such rertical movements throngh a long succession of geological periods. But the greater portion of the existing land of the globe, so far as known, lias been subject to repeated throes of elevation or depression. Such a eluange, if of notable amount, at length destroys the pre-existing relation of a region to its base-lerel of crosion. If it is depressed it beeomes immediately an area of deposition. If it is elevated new energy is imparted to the agents and machincry of erosion. The declivities of the streans are increased, giving an excess of transporting power which sweeps the channels clear of lébris; corlasion begrins; new topographical features are literally cinved out of the land in high relicf; long rapid slopes or cliffs are generated and vigorously attacked by the destroying agents; and the degradation of the conintry proceeds with cuergy.

It is not neeessiry that a base-level of erosion slonld lie at extremely low altitudes. Thus a large interior basin drained by a trunk river, across the lower portions of which a barrier is slowly rising, is a case in point. For a time the river is tasked to ent down its barrier as rap)illy as it rises. This oceasions slackwater in the conrses above the barrier and stops corrasion, produeing ultimately a loeal base-level. Another case is the Great Basin of Nevada. It has no outlet, because its streams siuk in the sand or evaporate from salinas. Its valley bottoms are rather below base-level than above it. The general result of cinses tending to bring a region to an approximate base-level of erosion is the obliteration of its inequalities. 
During the progress of the great denudation of the Grand Cañon District the indications are abmulant that its interior spaces have oceupied for a time the relation of an approximate base-level of erosion. 'Thronghont almost the entire streteh of Tertiary and Quaternary tine the region has been lising, and in the aggregate the elevation has becone immense, varying from 11,000 to 15,000 feet in different portions. But it seens that the movement has not been at a miform rate. It appears to have proceerled through alternations of activity and repose. Whether we can point to more than one period of quiescence may be somewhat doubtfin. but we can point lecisively to one. It occurred probably in late Miocene or early Pliocene time, and while it prevailed the great Carboniferous platform was denuded of most of its inequalities, and was planed down to a very flat expanse. Since that period the relation has been destroyed by a general upheaval of the entire region several thousands of feet. 'The indications of this will appear when we come to the study of the interior spaces of the Grand Cañon District and of the Grand Cañon itself. 'To this study we now proceed. 


\section{CHA P'TER V.}

'THE 'TOROWEAP' AND UINKARE'T

The present chapter will eontain an aeconnt of a jomrney from the village Kanab to the 'Toroweap) Valley, and a description of the middle, portion of the Grind Cañon; also of the Uinkaret Plateau. Kanab is the nsmal lallying place and base of operations of the survey in these parts, being located on the only living stream between the Virgen and the Paria.

The first stage of the journey from Kanab to Pipe Spring is an ealsy one. It leads sonthwestward to a gap cut throngh the low Permian terrace, and ont into the open desert beyond. The road, well traveled and easy, then turns westward and at length reaches the spring twenty miles from Kanab. Pine Spring is situated at the foot of the soutliermmost promontory of the Vermilion Cliffs, and is famons thronghout Southeru Utah as a watering place. Its flow is copious and its water is the purest and best throughont that desolate region. 'Ten years ago the desert spaces ontspreading to the southward were covered witl abmudiut grasses, afrording rich pasturage to horses ard cattle. Todaly hardly a blade of grass is to be found within ten miles of the spring, nnless upon the erags and mesas of the Vermilion Cliffs behind it. The horses and cattle have disappeared, and the bones of many of the latter are bleached mpon the plains in front of it. The camse of the failure of pastmrage is twofold. There is little donbt that during the last ten or twelve years the elinate of the surrounding comntry has grown more aricl. The occusional smmer showers which kept the grasses alive seldom come now, and throngh the long summer and autmmn droughts the grasses perished even to their roots before they had time to seed. All of them belong to varieties which reprodnce from seed, and whose roots live but thee or four years. Even if there had been no drought the feeding of cattle would have impoverished and perhaps wholly destroyed the grass by cropping it clean before the seeds were mature, as has been the case very generally throughout Utah and Nevada.

Northeastward the Vermilion Cliffs extend in endless perspeetive toWards Kanab, and beyond to the Paria. Northwestward, with growing magnitude, they extend towards the Virgen, ever forming a mighty backeromud to the picture. To the southward stretches the desert, blank, lifeless, and as expressionless as the sea. For five or six miles south of the Pipe Spring fromontory there is a gentle descending slope, and thence onward the surface feebly ascends throngh a distance of 
thinty miles to the brink of the Grand Cañon. Thus the range of rision is wide, for we overlook a gentle depression of great extent. Though the general impression eonveyed is that of a smooth or slightly modn. lated connty, fet we command a far greater expanse tlan would be possible among the prairies. To the sontheastward the Kaibab looms up, seemingly at no great distance, and to the sonthwestward the flat l'oof of Momt 'Trmbull is more than a blue eloud in the horizon. To. wards this latter momtain we tale a straight eourse. The first few miles lie across drifting sands bare of all regetation. The air is like a furnace, but so long as the water holds ont the heat is not enervating and brings no lassitude. Everything is calm and still, except here and there a hot whirling blast which sends up a tall, slender column of dust difliusing itself in the air. At a slow pace the sand-hills at length are passed and we enter upon a hard, firm soil, over which we move more lappidly. Just here, and for three or fonr miles in either direetion, the l'ermian terace has been obliterated. It has been beveled off by erosion and buried beneath the wash brought down from the foot of the Vermilion Clifls to the northward. Bnt seven miles from Pipe Spring, the Permian terace springs up ont of the earth, scarped by its characteristic cliff: Stretehing northwestward it inereases in altitude, beconing at last $\$ 00$ to 1,000 feet high. At its smmmit is seen the Shinarmmp conglomerate, of a pale brown color, ancl beneath are the gorgeons hnes of the shales. Nothing can surjass the dense, rich, and almost cloying splendor of the red-brown seen in these shales. They suggest the color of old maliogany, bnt are mueh more lnminous and quite uniform. Under them are helts of ehocolate, slate, lavender, pale Indian red, and white. Very wonderful, too, is the evenuess of the bedding, which is brought ont in great elearness and sharpuess by the etehing of minnte layers of clays holding selenite. Between the shales and overlying conglomerate careful seruting enables us to detect an unconformity by erosion with. out any meonformity of dip. As stated in a preeeding chapter, Mr. Woleot fixed provisionally the separating horizon between the Permian and 'rias at this unconformable contalet.

Along the ronte the regetation is seanty indeed. Several forms of cactus are seen looking very diseased and mangy, and remunts of low desert shrubs browsed to death by enttle. Yet strangely enongh there is one p'ant and one alone that seems to flonrish. It is the common sunflower (Helianthus lenticularis), fomd anywhere from Maine to Ari. zona, and seeming indifierent to the vicissitudes of elimate.

Abont 18 miles fiom lipe Spring the trail leads gently down into as broad shallow valley known as the Wild Band Pockets. The drainage from the fironts of the Permian cliffs now far to the northward here collects into a gulch, which gradually deepens and becomes a tributary of Kanab Cañon. In every stream-bed may be found many depressions which would hold water even though the sonrees of supply were ent off. This is as true of wet-weather chamels as of peremial streams. After 
the infrequent showers, and after the surface waters have ceased to l'un, the bed of the stream will still retain pools of water, provided the bottom of it is of a consistency whieh will prevent it from filtering away. To these pools the people of the west have given the name of "water-poekets." They are very common in the stream-beds which bear away the wash from the Permian and lower Triassie shales. These shales yield a very fine impervious clay, which forms an excellent "pnddling" for water holes and basins. The Wild Band Pockets have received their name from the finet that they are the resort of bands of wild horses that roam over these deserts, far from human ham th, ranging from spring to spring, which they visit by stealth only at night, and never so long as they can ind chance water in these and other pockets. Beyond the Wild Band Valley there is a slight ascent to a rocky platform, consisting of the smmmit beds of the Carboniferons. In the course of 20 miles we have crossed the entire Perman series, which now lies to the north of us. A few stmuted eedars, most of which are dead or dying of drought, are scattered over this platform and give us until niglitfall some slight shelter from the smu. It is as good a camping place as we are likely to find, and if we are fortmute enough to reach it after a eopions shower, the hollows and basins in the flat roeks may contain a seanty supply of clear rain-water. It is a good locality, also, from which we may overlook the ontspreading desert, whieh is not withont eharms, however repulsive in most respects.

To the northward rises the low escarpment of the Permian, forming a color picture which is somewhat indistinct turough distanee, but weird beeause of its strange eolors and still stranger forms. Beyond and in the fur distance rise the towering fronts of the Vermilion Cliffs, ablaze with red light from the sinking sum. "To the eastward they streteh into illimitable distance, growing paler but more refined in color until the last visible promontory seems to merge its pmrple into the azure of the evening sky. Across the whole eastern quarter of the lorizon stretches the long level summit of the Kaibab as straight and mbroken as the rim of the ocean. To the southwestward rises the basaltie platean of Momt Trumbull, now presenting itself with somewhat imposing proportions. Aromnd it a great multitnde of basaltie cinder eones toss up) their ominous blaek wares almost as ligh as Trmmbull itself. Their tmmultuons profiles and gloomy shades form a strong eontrast with the rectilinear cutlines and vivid colors of the region romdabont.

At dawn we move onward, reaching soon the summit of a hill which descends two or three hmolred feet to a broad flat depression ealled the Wonsits Plain. It is a smooth and very barren expanse, dotted with a few molkering bnttes of Upper Carboniferons rocks, now wasted to their foundations. The plain is abont seven miles in width, and on the further side rises a low mesa of great extent capped with basalt. It is the Uinkaret. Beyond the nearer throng of basaltic eones Mount Trumbull rises with a striking aspect dominating strongly the entire western 
landscape. The smaller cones are now seen to be very mumerons, and all of then are apparently perfect in form, as if time had wronght no great ravage anong them. The lapilli and peperino with which they are covered, has become dull red by the oxidation of the iron, and this peculiar color is easily recognized though the cones are still far away. Just before reaching the basaltic mesa we must make our choice between two routes to the Toroweap, one direct, the other very circuitous. No spring is to be fonnd until we reach the further side of Nount Trumbull, bnt we know of a large water-pocket on this side, which has never been known to dry up. The spring water is sure to be good, bnt the water in the pocket will depend for its quality upon the length of time which has passed since the last heary rain. Tet 'ns lrere choose the shorter one, and go to the water-pocket.

Ascending the mesa which rises abruptly abont 200 feet above the Wonsits Plain, we find ourselres at once upon the basalt. The ground is paved with cinders and fragments half buried in soil, the lébris of decaying lava sheets. These sheets are rarely of any great thickness, seldom exceeding 30 or 40 feet, and often much less, and none of the individual eruptions of lava seem to have covered any very great expanse. Probably the area covered by the largest would be less than a square mile. They show no perceptible differences in composition or' texture, and all are basalts of the most typical variety-rery black and ferruginous in the unweathered specimens and speckled with abundant olivine. At the time of emption they appear to have been in a state of perfect liquidity, spreading ont very thin and flowing lapidly and with - ease. In none of them has erosion wrought much havoe, though here and there some local destruction has been efrected, most conspicuously upon the edges of the principal mesa where the sheets have been undermined and their fragnents scattered upon the plain below. The cones, which stand thick around us, are still in good preservation. They are of ordinary composition-mere piles of cinders thrown ont of central vents and dropping around it. The fume and froth of the lava surfices, the spongy inflated blocks, the lapilli and peperino, are not greatly changed, though all of them here show the oxidation of the iron. We wonder what their age may be; what time has elapsed since they vonited fire and steam. But there is no clew-no natural record by which such erents can be calendared. Historically they have donbtless stood in perfect repose for very many centuries. Not a trace of alctivity of any kind is visible, and they are as perfectly quiescent as the dead volcanoes of the Anvergne or of Scotland. Geologically, they are extremely recent; yet even here where historic antiquity merges into geologic recency the one gives us no measure of the other.

Following a conrse which winds among the silent cones and over rough, flat surfaces of lara beds half bmried in drifting sands, we at length reach the border of a slight depression, into which we descend. It is hardly noteworthy as a valley just here, and might be confounded 
with any one of the innumerable shallow-water courses which occur round about; only when we look beyond we see it growing broader and much deeper. It is the head of the Toroweap. Upon its smooth bottom is a soft clayey soil, in which desert shrubs and stunted sage-brush grow in some abundance. Here and there a cedar, dwarferl indeed, but yet alire, displays a welcome green, and upon the valley slopes are a few sprays of grass. The valley bottom descends at a noticeable rate to the southward, and as we put the miles behind us we find the banks on either side rising in height, becoming steeper, and at last displaying roeky ledges. In the course of six or seven miles the left side has become a wall 700 feet high, while the other sille, somewhat lower, is much bruken and craggy. Huge piles of basalt lie upon the mesa beyond, slicet upon sheet, culminatiug in a cluster of large cones. At length the course of the valley slightly deflects to the left, and as we clear a shoulder of the eastern wall, which has hitherto masked its continuation, a grand vista brealis npon the sight. The valley stretehes away to the sonthward, ever expanding in width; the walls on either side increase in altitude, and assume profiles of wonderfinl grace and nobility. Far in the distance they betoken a majesty and grandenr quite unlike anything litherto seen. With vast proportions are combined simplicity, symmetry, and grace, and an arehitectmal effect as precise and clefinite as any to be found in the terraces. And yet these walls differ in style from the Trias and Jura as much as the Trias and Jura differ from each otler. In the background the vista terminates at a mighty palisade, stretehing directly aeross the axis of vision. 'Thongh more than 20 miless distant it reveals to us suggestions of grandeur which awaken feelings. of awe. We know instinctively that it is a portion of the wall of the Grand Cañon.

The western side of the valley is here broken down into a long slope descending from the cones ehnstered around the base of Mount Trumbull, and covered with broal flows of basalt. 'Turning ont of the valley we ascend the lava bed, which has a very moderate slope, and about a mile from the valley we find the Witclies' Water Pocket. In every desert the watering places ate memorable, and this one is no exception. It is a weird spot. Around it are the desolate Phlegraean fields, where jagged masses of black lava still protrude through rusty, decaying cinders. Patehes of soil, thin and coarse, sustain groves of cedar and piñon. Bejond and above are groups of eones, looking as if they might at any day break forth in renewed eruption, and over all rises the tabular mass of Monnt Trumbnll. Upon its summit are seen the yellow pines ( $P$. ponderosa), betokening a cooler and a moister chime. The pool itself might well be deemed the abode of witehes. A chamnel half-a-dozen yards deep and twice as wide, has been seonred in the basalt by spasmodic streams, which rin during the vermal rains. Such a stream eascading into it has worn ont of the solid lava a pool twenty feet long, nearly as wide, and five or six feet deep. Every flood 


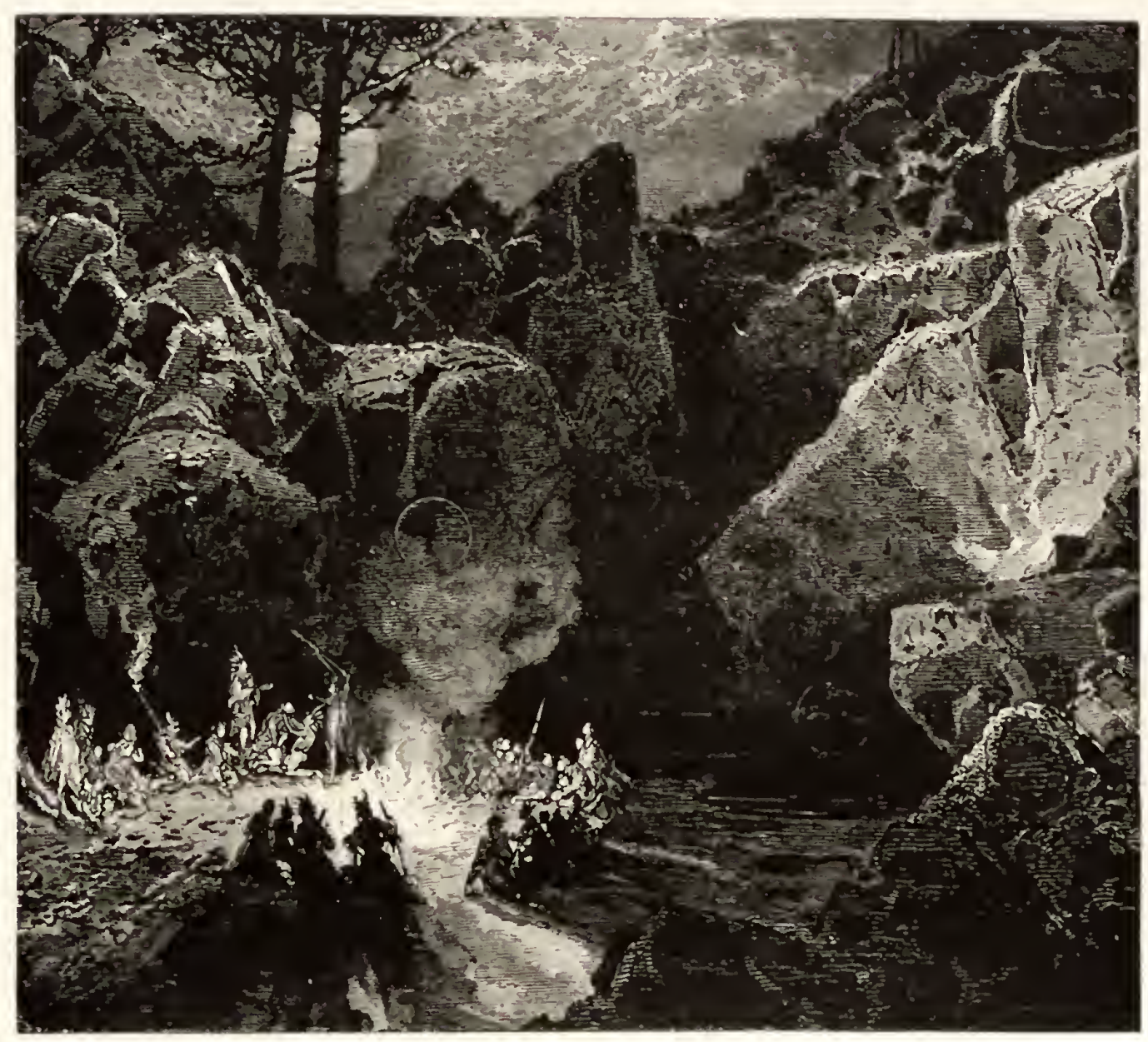

lik, T.-T'he Witches' Water Pocket.

fills it with water, which is good enough when recent, but horrible when old. Here, then, we camp for the night.

Filling the kegs at daylight, we descend again into the Toloweap and move soutlrward. Oul attention is strongly attracted by the wall upon the eastern side. Steadily it increases its mass and proportions. Soon it becomes evident that its profile is remarkably constant. We did not notice this at first, for we saw in the upper valley only the summit of the palisade; but as the valley cuts deeper in the earth the plan and system begin to unfold. At the summit is a rertical ledge, next beneath a long Mansard slope, then a broad plinth, and last, and greater than all, a long, sweeping curve, lescending gracefully to the plain below. Just opposite to us the pediments seem half buried, or rather half risen out of the valley alluvinm. But beyond they rise higher and ligher until in the far distance the profile is complete. In this escarp). ment are excavated alcoves with openings a mile wide. As soon as we reach the first one new features appear. The upper ledge suddeuly breaks out into a wealth of pinnacles and statues standing in thick ranks. 'They must be from 100 to 250 feet high, but now the height of the wall is more tham a thousand feet, and they do not seem colossal. Indeed, 

they look like a mere band of intricate fretwork-a line of balnstiade on the summit of a noble façade. Between the alcoves the projecting pediments present gable-ends towards the valley plain. Yet whithersoever the curtain wall extends the same profile greets the ejes. The architect has adhered to his design as consistently and persistently as the builders of the Thebaid or of the Acropolis. As we pass aleove after alcove, and pediment after pediment, they grow loftier, wider and deeper, and their decoration becomes more ornate. At length we pass one which is rast indeed. It is recessed back from the main front threefourths of a mile, and shows three sides of an oblong room with walls 1,800 feet in height. The fontly side is obliterated and the space opens into the broal valley. Wonderfnlly rich and profise are the pimacles and statnes along the upper friezes. The fancy is lindled as the eye wander's through the inclosure.

We look across the valley, which is here three miles in width, and behold the other wall, which presents an aspect wholly different, but quite as interesting. 'The westen wall of the 'loroweap is here lower than the eastern, but still is more than a thousand feet high. The geologist soon surmises that along the valley bottom runs a fault which drops the comntry on the west several hundred feet, and the conjecture soon becones certainty. Above and beyond the western escarpment is the platform of the Uinkaret Platean. Upon its summit is a throng of large basaltie cones in perfect preservation. Streams of lava larger than any hitherto seen have poured from their vents, flooding many a square mile of mesa land, and in the wide alcoves they have reached the brink of the wall and caseaded over it. Still pouring down the long talnses they have reached the valley bottom below and spread ont in wide fields, disappearing underneath the clayey alluvium, which has buried much of their lower portions. The appearance of these old lava cascades, a mile or more wide, a thousand feet high, and black as Erebus, is striking in the extreme. There are five of these basaltic cataracts, each consisting of many individual coulées. Between them the bold pediments of brightly-colored Carboniferous strata jut out.into the valley.

At length we approach the lower end of the Toroweap. The scenery here becomes colossal. Its magnitude is by no means its most impressive feature, but precision of the forms. The dominant idea ever before the mind is the architecture displayed in the profiles. It is lind to realize that this is the work of the blind forces of nature. We feel like mere insects crawling along the street of eity flanked with immense temples, or as Lemuel Gulliver might lave felt in revisiting the capital of Brobdingnag, and finding it deserted. At the foot of the valley the western wall is nearly 1,500 feet high, the eastern abont 2,000, and the interval separating them is abont three miles. Suddenly they tmm at right angles to right and left, and become the npper wall of the Grand Cañon of the Colorado. The Toroweap now opens into the main passageway of the great chasm. 'The view, however, is much obstructed. 


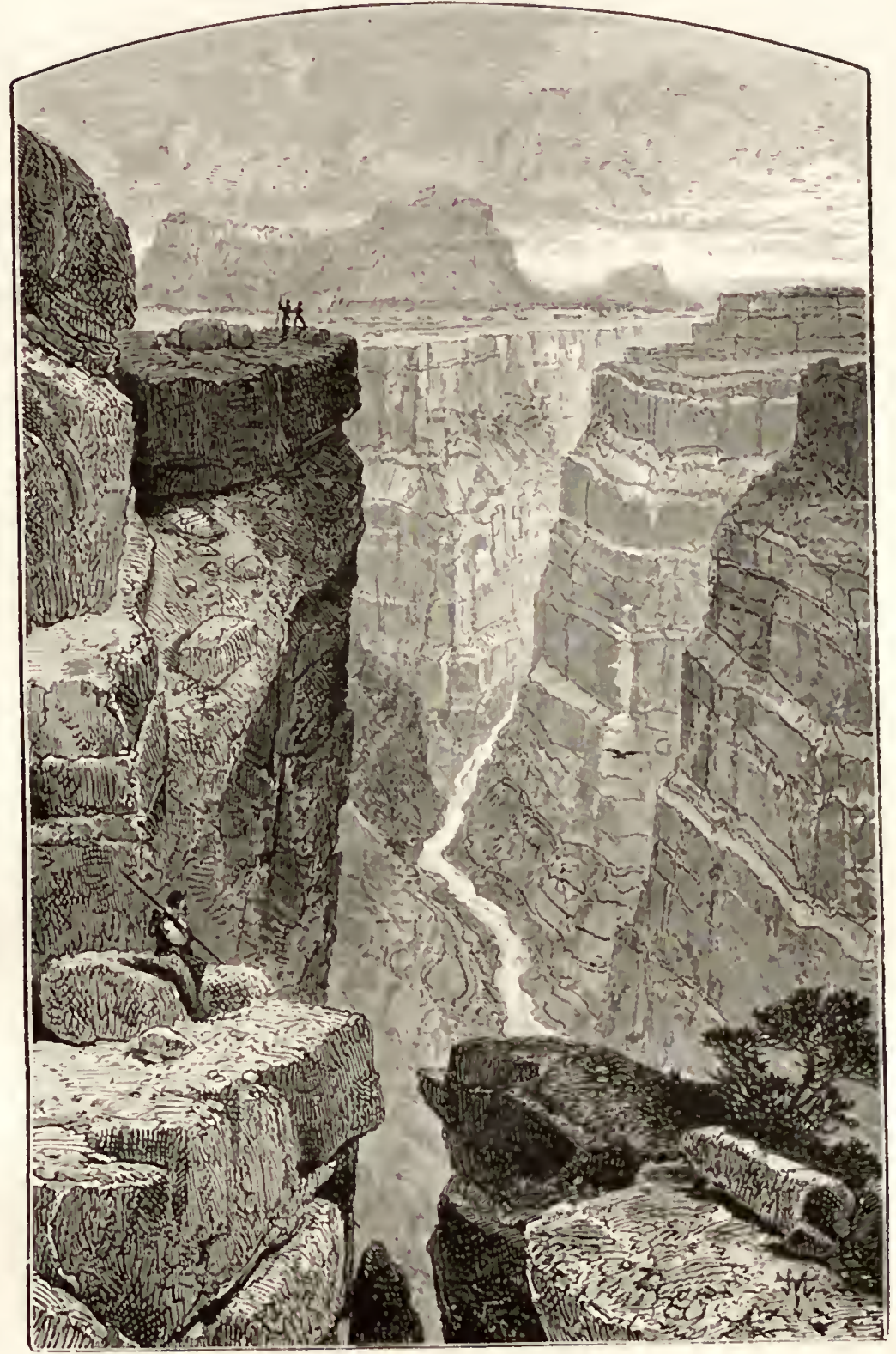

Fig. 8.-The brink of the Inner Gorge at the foot of the loroweap, looking east.

At the foot of the eastern gable is a medley of rocky ledges of red sandstone, while around the base of the western gable are large masses of basalt reaching more than half-way across the ralley. In front rises a crater, which is about 600 feet high, seemingly a mere knoll in the millst of this colossal scenery. Bejond it, and five miles distant, rises the palisade which forms the sonthern upper wall of the chasm, stretching athwart the line of vision interminably in either direction. Its altitude is apparently the same as that of the palisade above us, and its profile is also identical. Climbing anong the rocky ledges which lie at the base of the escarpment, we at length obtain a stand-point which enables us to gain a preliminary view of the mighty arenue. 'To the eastward it streteles in vanishing perspective forty miles or more. Between symmetric walls 2,000 feet high and five miles apart is a plain, which in 
Tive (1)

Int

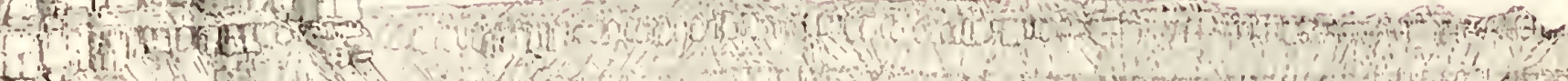

H.

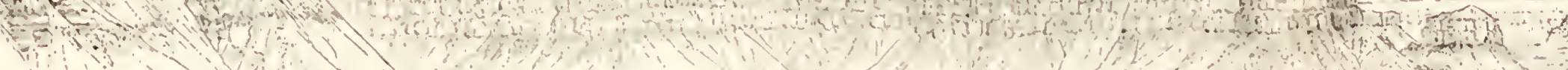$$
\text { (2) }
$$
D.

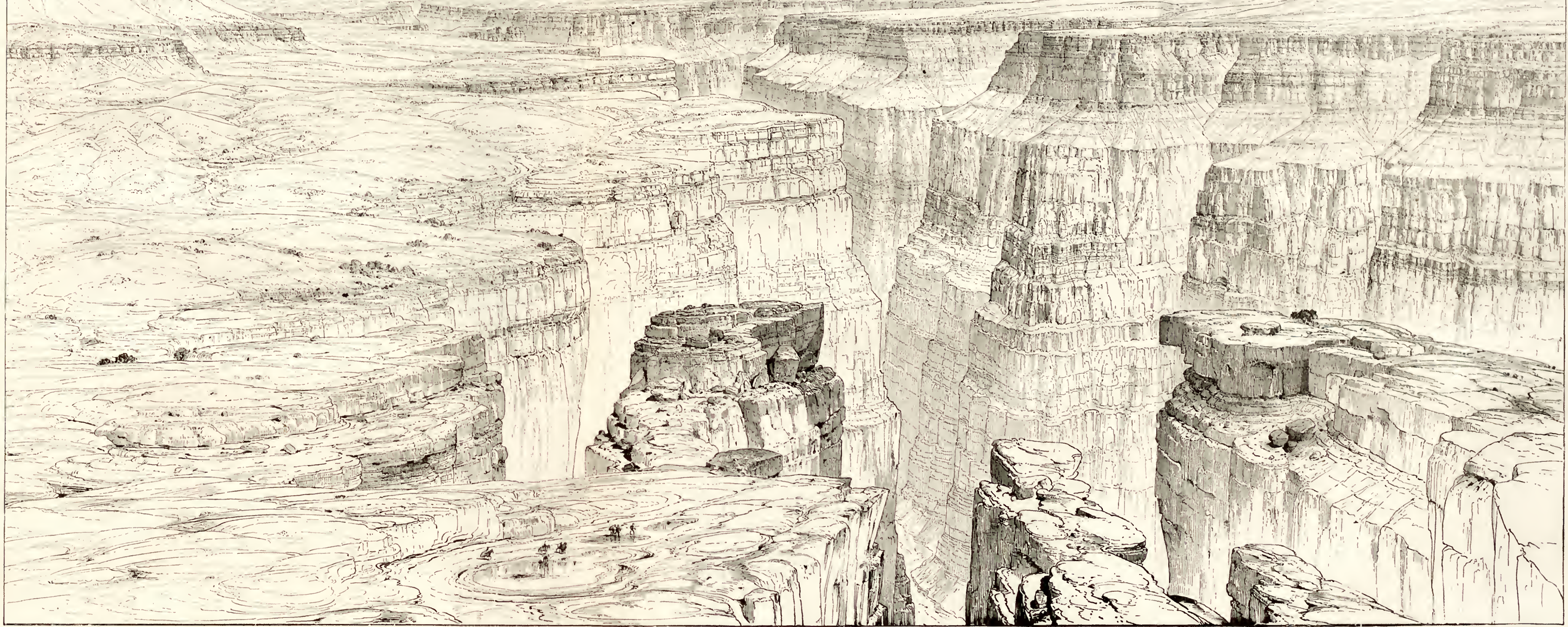


comparison with its limiting eliffs might be regarded as smooth, but which in reality is diversified by rocky lmmmocks and basins, and by hillocks where patches of soil give life to seattered eedars and piñons. Of the imner chasm nothing as get is to be seen. Moving ontwand into this platform we find its surface to be mostlj bare rock, with broal shal. low basins etched in then, which hold water after the showers. 'There are thousands of these pools, and when the showers have passed they gleam and glitter in the sun like immmerable min'rors. As we move ontward towards the center of the grand arenue the immensity and beantifnl proportions of the walls develop. The vista towards the east lengthens out and vanishes against the bhe ramp of the Kabab, which lies as a clond upon the horizon. To the west the view is less symmetric and regular, and the eye wanders vaguely anong chifts and buttes of stupendous magnitude, displaying everywlere the profile with which we have become of late familiar. Nuch of the distance towards the west is obstructed by the crater, but the portions in view bewilder us by the great number of objects presented, and oppress us by their nagnitudes. At a distance of abont two miles from the base of the northern wall we come suddenly upon the inmer ehasm. We are not conscions of its proximity mitil we are within a few yards of it. In less than a minnte after we have recognized the erest of the firther wall of this abyss we erane over its terrible brink and gaze upon the waters of the river full 3,000 feet below.

The scene before us is a type of the Grand Cañon throughout those portions which extend through the Kanab, Uinkaret, and Shearwits Plateans. The plan and section here presented are quite simple. 'They consist of' a broad upper chasm from five to six miles in width with walls varying in altitude but little from 2,000 feet. Between these escarpments is a roeky plain, rongh indeed, but in the overpowering presence of sneli walls seeming relatively smooth and uniforn. In this floor is ent the inner chasm 3,000 feet deep and fiom 3,500 to 4,000 feet wide from crest to erest. 'The trne profile will be best understood by consulting the diagram, Fig. 10, which is drawn to scale. The strata in which the ehasm is excavated are all of Carboniferous age excepting three or four hundred feet at the botton of the gorge. 'The strata beneath the Carboniferons are at present believed to be Lower Siln rian, and their contact with the Carboniferons is meonformable, both by dip and by erosion. In the up). per part of the palisades which form the wall of the upper ehasm we find at the summit two series of limestones. 'The upper contains an abundance of siliceons matter, one portion of which is intimately dis. seminated through the mass while another portion is aggregated into my riarts of eherty nodules varying from two to ten inches in diameter. The lower one is a purer limestone with few nodules. The cherty members form a nearly vertical band at the summit of the wall; the purer members form a Mansard slope beneath, covered with talus. The total thickness of the limestones is about 700 to 750 feet. Beneath them eome 


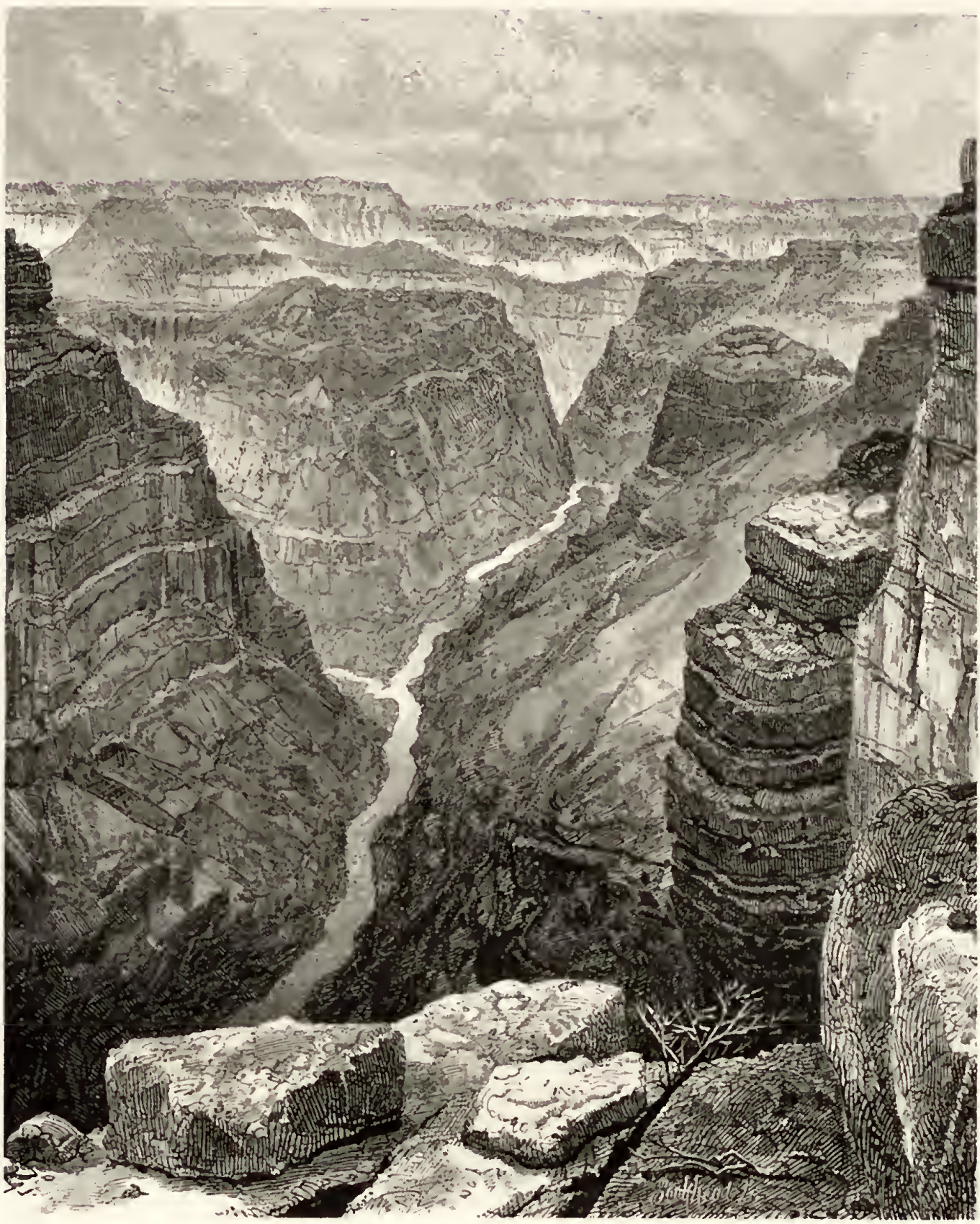

Fif, 9. The brink of the lnner Gorge at the find of the Torowetp, lookint west.

sandstones a little more than 250 feet thick, which form everywhere a verticat plinth or frieze. They are very admantine in texture, and one of the members, about 100 feet thick, is in every exposure seen to be uniformly cross-bedded. Under the cross-bedded sandstone is a mass of thinly bedded and ahnost shaly sandstones, having an aggregate thickness very closely approximating to 1,000 feet. They are of an intensely brilliant red color, but are, in greatest part, covered with a heavy talus of imperishable cherty nodules, fragments of the crossbedded sandistones, and spalls of limestone shot down from above. The color of these is pale gray, with occasionally a yellowish or creany tinge. 
The brilliant red sandstones form the long eurved slope which descends from the plinth of cross-bedded sandstone to the plinin below.

The walls of the immer gorge have at the summit about 325 feet of hard sandstone of a brown-red eolor. Beneath the sandstone are about 1,800 feet of inpure limestone in layers of the most massive deseription. Very few such pouderous beds of limestone are found in any part of the world. The color is deep red with a purplish tone, but the brillianey of the coloring is notably weakened by weath. ering. Still lower are red-brown sandstones again having a dark and strong shade and lying in very massive beds. The strata forming the walls of the outer ehasm from the summit to the plain below are designated the Aubrey group, and this is again subdivided at the base of the eross-bedded plinth into Upper and Lower Aubrey groups. The two subdivisions are believed to be the equivalents, in age, of the Coal Measures of Pennsylvanial and England. The strata disclosed in the inmer gorge eorrespond in age to the Lower Carboniferous of those comntries, and are here termed the Red Wall group. Some uncertainty exists legarding the beds which lie at the base of the eonformable series deep down in the chasm, but they are regarded at present as being just what they seem and just what they would nat. urally be inferred to be-a part of the Carboniferous system. Of the strata at the bottom of the cañon, we shall have more to say hereafter. 'They are regarded at present as being of Lower Silurian or Primordial age.

The observer who, unfamiliar with plateau scenery, stands for the first time upon the brink of the inner gorge, is almost sure to view his surroundings with eommingled feel. ings of disappointment and perplexity. The fime of the chasm of the Colorado is great; but

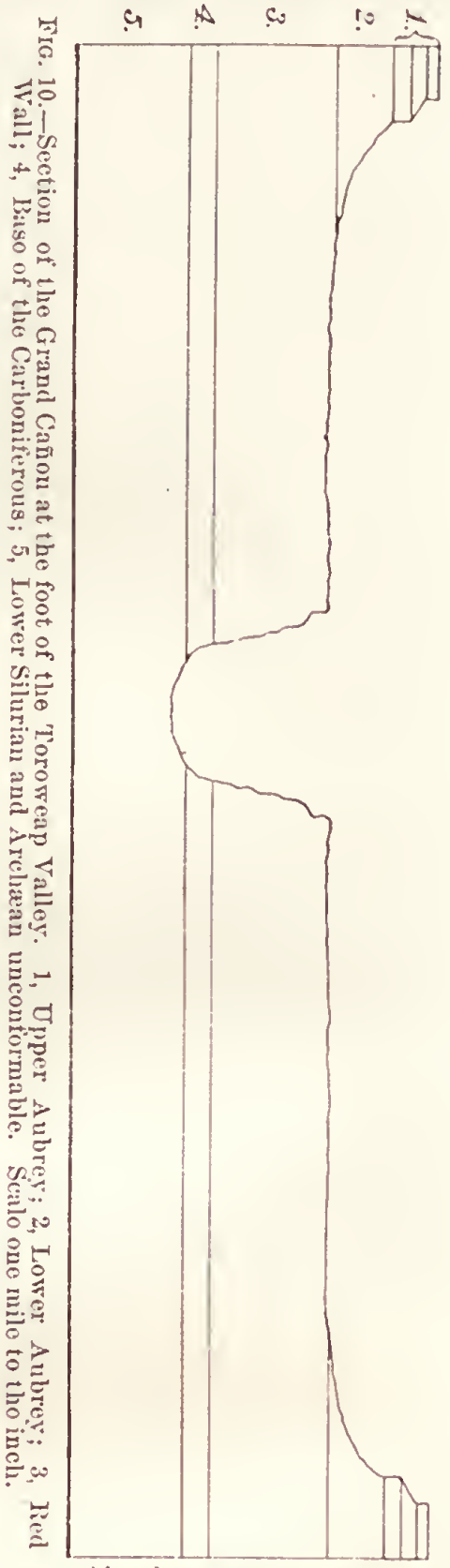
so indefinite and meager have been the descriptions of it that the inagination is left to its own deviees in framing a mental eoneeption of it. And such subjective pictures are of eourse wide of the truth. When he first visits it the preconecived notion is at once dissipated and the mind is slow to receive a new one. The ereations of his own fancy no doubt are elothed with a vague grandeur and beauty, butnot with the grandeur and beauty of nature. When the reality is before him the impression bears some analogy to that produced upon the visitor who for the first time 
enters St. Peter's Church at Rome. He expected to be profomilly are. struck by the unexampled dimensions, and to feel exalted by the beanty of its proportions and decoration. He forgets that the human mind itself is of small capacity and receives its impressions slowly, by labored processes of comparison. So, too, at the brink of the chasm, there comes at first a feeling of disappointment; it does not seem so grand as we expected. At length we strive to make comparisons. The river is clearly defined below, but it looks about large enough to turn a village grist-mill; yet we know it is a strean three or four hundred feet wide Its surface looks as motionless as a lake seen from a distant mountaintop. We know it is a rushing torrent. The ear is strained to hear the roar of its waters and catches it faintly at intervals as the eddying breezes waft it upwards; but the sound seems exhausted by the distance. We perceive dimly a mottling of light and shadow upon the snrface of the stream, and the flecks move with a barely perceptible clond-like motion. They are the fields of white foam lashed np at the foot of some cataract and sailing swiftly onward.

Perhaps the first notion of the reality is gained when we look across the abyss to the opposite crest-line. It seems as if a strong, nervous arm could hurl a stone against the opposing wall-face; but in a moment we catch siglit of vegetation growing upon the very brink. There are. trees in scattered groves which we might at first have mistaken for sage or desert furze. Here at length we have a stadium or standard of comparison which serves for the mind much the sane purpose as a man standing at the base of one of the sequoias of the Mariposa grove. And now the real magnitudes begin to unfold themselves, and as the attention is held firmly the mind grows restive under the increasing burden. Every time the eye ranges up or down its face it seems more distant and more vast. At length we recoil, overburdened with the perceptions already attained and yet half rexed at the inadequacy of our faculties to comprehend more.

The magnitude of the chasm, however, is by no means the most im. pressive element of its character; nor is the imrer gorge the most impressive of its constituent parts. The thoughtful mind is far more deeply moved by the splendor and grace of Nature's architecture. Forms so new to the eulture of civilized races and so strongly contrasted with those which have been the ideals of thirty generations of white men camot indeed be appreciated after the study of a single hour or day. The first conception of them may not be a pleasing one. They may seem merely abnormal, curious, and even grotesque. But he who funcies that Nature has exhansted her wealth of beauty in other lands stringely underestimates her versatility and power. In this far-off desert are forms which surprise us by their maceustomed character. We find at first no place for them in the range of our conventional notions. Bnt as they become familiar we find them appealing to the æsthetic sense as powerfully as any scenery that ever invited the pencil of Clande or' of 'Turner. 
The immer gorge, as we sit upon its brink, is indeed a mighty spectacle; but as we withdraw a little, it fades out of view, and, strangely enough, the sublimity of the scene is not very greatly impaired. It is, after all, a mere detail, and the onter chasm is the all-engrossing feature. On either side its palisades stretch away to the horizon. Thror fronts wander in and out, here throwing out a gable, there receding into a chamber, $\mathrm{or}^{\circ}$ gaping widely to admit the entrance of a lateral chasm. The profile is ever the same. It has nothing in common with the formless, chatic crags, which are only big and rongh, but is definte, graceful, architectural, and systematic. The width of the space inclosed between the upper walls is one of the most essential elements of the grandeur. It varies from five to six miles. If it were narrower the effect would be impaired; nor could it be much wider without diluting and weakening the general effect. This proportion seems quite just. It is a common notion that the distinctive and overuling feature of the great chasm is its narrowness relatively to its depth. No greater mistake cond be made. Onr highest conceptions of grandenr are most fully realized when we ean see the greatest mass. We must have amplitude in all of the three dimensions, distance, breadth, and depth, and that spectacle is in point of magnitude the grandest which las the three dimensions so proportioned and combined as to make the most of them. Another common and mistaken idea is that the chasm is pervaded by a deep, solem gloom. The truth is almost the reverse. In the depths of the inner gorge there is a suggestion of gloom, but even in the narrower portions there is seldom less than sixty degrees of sky from crest to crest, and a hundred and sixty along the track of the river. In the outer chasm the scene is musually bright. The npper half of the palisates have a pale, ashy, or pearl-gray color, which is very lustrons, and this sometines gives place to a creany or Naples yellow tint in the frieze of cross-bediled sandstone. The Lower Aubrey sandstones are bright red, but they are in great part masked by the talus shot down from the pale gray limestones above, and peep out in lustrous spots where the curtain of the talus is drawn aside. There is nothing gloomy about such colors. Under a burning sun that is rarely clouded they have a brilliancy seldom seen in any rocks, and only surpassed by the sugary whiteness of the Jurassic sandstone or the brilliant red of the Vermilion Cliff's.

Directly in the sontluward prolongation of the axis of the Toroweap Valley there stands a basaltic cinder-cone inmediately upon the brink of the inner gorge. Its altitnde above the surrounding plain is 580 feet. The summit is readily gained, and it is an admirable stand-point from which the entire panorama nay be viewed. IVe named it Vulcan's Throne. To the eastward abont forty miles of the main chasm are well in view. 'The altitude of the cone, though small in comparison with survounding objects, is sufficient to bring into view about twelve miles of the opening of the inner gorge, while in the foreground its depths are seen. To the westward the scenery is much more broken and 
diversitied. The chasm is seen throngh the entire stretch in the Uinkaret Plateau and reaching a few miles into the Sheavwits. But about twenty miles westward it makes a sonthward turn and disappears. From the north the Toroweap Valley descends from near Mount T'rum. bull. It is cut down only to the base of the upper cañon wall and opens into the main chasm on the level of the plain above the inner gorge. There is reason to believe that at some prior epoch it was cnt a few hundred feet deeper than its present floor, and was subseqnently bnilt up by many floods of basalt coming from the cones on the Uinkaret and by considerable quantities of alluvinm washed from its cliffs and overlooking mesas. On the sonth side of the Grand Cañon is a valley quite the comuterpart of the Toroweap. It enters the main cliasm directly opposite to the Toroweap, so that the two form the arms of a transept, the main chasm being regarded as the nave. Vulcan's Throne is sitnated almost exactly at the intersection of the axes of nave and transept.

It wonld be diffienlt to find anywhere else in the world a spot yielding so much subject-matter for the contenplation of the geologist; certainly there is none situated in the midst of such dranatic and inspiring snrromdings. The chasm itself, with its marvelons story of erosion, and the two lateral valleys adding their quotas of information are grand subjects indeed; but other themes are disclosed which are scarcely less surprising and suggestive. The cone stands inmediately upon the line of a large fanlt. And never was a fanlt and its consequences more clearly displayed. The toroweap fanlt is one of six which at wide intervals traverse the Grand Cañon district from uorth to south with a rude approximation to parallelism. It is the smallest of the six. Twenty miles north of the chasm no trace of it is visible. Its beginning there is small, but as it approaches the chasm it increases in the amount of displacement; and at the crossing of the river the shear or "throw" is between 600 and 700 feet. In the wall-face of the inne' gorge it is disclosed is clearly as a dranghtsulun conld delineate it on paper. The masses of horizontal limestones and sandstones, displaying their fretted edges and lines of bedding, advance from the eastward in the face of the wall until they reach the vertical fault plane. Then they "break joints" and drop at once six or seven lmndred feet, an? continue westward as before, but at a lower level. The whole topog. raphy goes with it. Looking beyond to the npper wall of the outer chasm the "jog" where the break occurs is plainly seen. The whole platform of the conntry is dropped to the westward. The plain between the npper palisades descends by a single step from east to west aeross the fault by an amonnt equal to the displacenent, and the inner gorge and the whole chasm beconiles by so numch reduced in depth.

Excepting the dislocation itself, the finlting does not appear to have been accompanied by any injury to the strata. Yot a trace of shattering, crumbling, or mashing of the beds is discernible. All looks as clean and sharp as if it had been cut with a thin saw and the smooth 


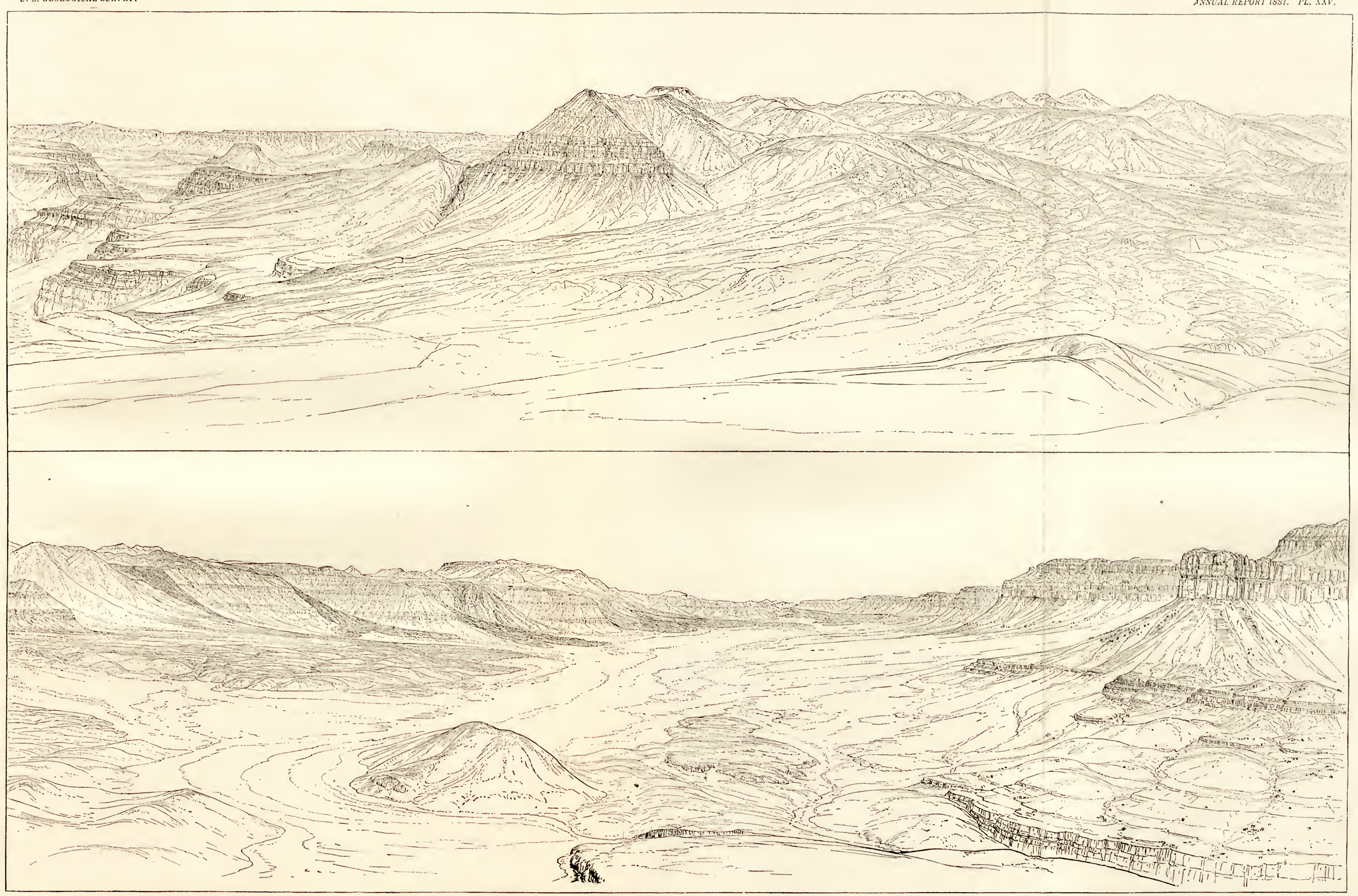


faces pressed neatly together. But the only attainable view of it is from the distance of a mile. Yet miles here are less than furlongs in other countries, and all letails as well as broader features are upon the Brobdingmigian scale. What a nearer view might disclose is of course impossible to conjecture. The plane of the funlt is about vertical, though there seems to be a slight inclination to the east, which may be apparent only and a result of perspective.

After a careful stndy of the surroundings of the fanlt, it becomes apparent that it is of recent occurrence in comparison with other events which have been in progress here. The tenor of all evidence bearing upon the subject goes to show that these faults were not suddenly pro. duced by violent convulsions, but giadually developed through long stretehes of time, and inch by inch or foot by foot. The Toroweap fault gives no evidence of being exceptional in this respect. Its recency is diselosed by many facts. It is seen that the amount of erosion in the face of the transverse "cliff of displacement" produced by the faulting is very small. This cliff has not receded from the fanlt plane to any considerable extent. Yet the giant palisales which wall the outer chasm have receded from the mediun line of the cañon more than two miles sinee the corrasion of the river laid bare the edges of their strata. It seems very plain that the outer chasm had been formed and attained very nearly its present condition before the fault started. Bnt there is still more conclusive evidence of reeency. At the foot of the sonthern palisade and at the jaws of the lateral valley are several basaltic craters. They look like mere bee-hives muder the eaves of such an escarpment, though in truth they are four or five hundred feet high. From their vents streams of basalt are seen flowing down into the lateral valley across the fault plane, and clear to the brink of the immer abyss. 'The fault shears the lava floods as neatly as it does the Red Wall limestone.* Many other facts might be eited to the same purport, but this one is so conclusive that nothing further is neeessury. We shall find similar evidences of recency when we come to the study of the great Hurricane fault.

Another subject which will awaken the enthusiasn of the geologist who visits this unique spot is the volcanic phonomena. 'Tuming to the northwestward le beholds the heights of the Uinkaret. Upon its broad expanse stand many basaltic eraters in perfect preservation. We know of about a hundred and fifty distinct cones in this platean, ineluded in the space which lies between the Grand Cañon and a limit forty miles north of it. But it is in the vicinity of the chasin that they cluster most thickly together and present the largest proportions. This part of the Uinkaret is thickly covered with basalt, above which rises the tumnltu-

\footnotetext{
* It seemed to me, so far as could be julged from a distance, that a part of the fiulting had been accomplished before the lava outlowed. 'Tho main fact, however, is elear that most of the faulting took plaee after the eruption, and of course settles the question of relative age or recency.
} 
ous throng of eraters. Very many wide and deep thoors of basalt liave poured over the edge of the platean into the lower 'Ioroweap Valley and upon the great esplanade of the cañon, 1,500 to 1,800 feet below, and, spreading out into wide fields, have reaehed the brink of the inner gorge. Pouring over its brink, the fiery caseades liave shot down into the abyss and pursued their way many miles along the bed of the river. At one epoch they had built up the bed of the Colorado about 400 feet, but the river has seoured out its chamnel again and swept them all away, regaining its old level, and is now eutting the sandstones below. 'The spectacle of the lava floods deseending from the Uinkaret, as seen from Vulean's 'Throne, is most imposing. It tells the story so plainly that a child could read and understand it. Compared with many elassic volcanic regions the volcanism of the Uinkaret is a small affair. In those classie regions the mind does not come into direct eontact with the enormity of the faets by a single glanee of the eye. But. here, if lind Asmodeus were to lift the basaltie roof of the platean, we should see no more than we do now. The boldness of the picture is much increased by the pediments of Carboniferous strata projeeting from the body of the plateau, slowing the brilliant eolors of the strata and their sharply-defined architeeture, with the darli masses of basalt wrapping around them. Hard by, and almost within lrail, is a superb gable projecting between two broad floods of lava, and so beatifully proportioner and richly colored that we cammot help wishing to transport it by magie to some inore habitable region.

The Toroweap Valley has a significance to the geologist which might not be at onee apparent to the tourist. Even the geologist would be slow to discern it unless familiar with eognate fircts displayed in the country at large bordering the Grand Cañon. In the effort to interpret its meaning it beeomes necessary to take a hasty view of one or two broad faets relating to the lateral drainage of the elrasm. Upon the north side, in all the distance between the head of the Marble and the foot of the Grand Cañons, there is but one side eañon earrying drainage from distant regions. This single exception is Kanab Cañon. In this respeet the Colorado is muclr like the lower courses of the Nile; and the cause is plainly the same. The region is too arid to sustain any living stremns or even to keep open the conduits which in former periods might have sus. tained them. Yet upon the assunption that at some former period the climate was much more hmmid all analogy eompels us to believe that the Colorado onee received many tributaries which are now extinet, and upon examination we find good evidenee that this was really the ease. The 'loroweap Valley is the modified chamnel of an ancient river. On the west side of the Uinkaret is amother. A third is seen upon the south side of the Colorado, directly opposite the Toroweap; and a few others may be easily designated. It appears that all these rivers dried up before the inner gorge was exeavated. For if they had continued to earry water we may be sure that they would hive eut their chisms is 
deep as the Grand Cañon itself-just as the Little Colorado, Kanab Creek, and Cataraet Creek have done. For we have only to look at the great multitude of lateral ehasms of the upper courses of the Colorado and of its forks, the Grand and Green, to be deeply impressed with the fact that so long as a tributary river earties, we will not say a living stream, but even oceasional floods, its chamel will be seoured down to the same level as the trunk river itself: It is apparent, then, that the Toroweap dried up before the eutting of the inner gorge of the Grand Cañon began, and hence we infer that the arid elimate which caused it to dry up existed before the beginning of the inner gorge.

By the applieation of other homologons facts, and by the same method of reasoning, we infer that the outer ehasm has also been excavated during the prevalence of an arid climate. The platform of country adjoin. ing the cañon is at present devoid of lateral ehasms, yet traces are often found of ancient ehannels whieh beeame dry at about the time the exeavation of the outer cañon began, or very soon thereafter. They are cut to comparatively slight depths-from one hundred to three or four lumdred feet. That they are not of recent origin is proved by the fact that they often have slopes away from the river, thougl it is elear that they formerly sloped towards it. In truth, the entire ehasm betrays everywhere the eontinued action of an arid climate through the entire period of its formation. This arid period is limited, approximately, to Pliocene and Quaternary time. The general tenor of the facts is to the effeet that the Miocene was a humid period and the Plioeene a dry one throughout the greater part of the West. This is one of the reasons which lead us to the very probable courelusion that the age of the Grand Cañon is not older than the beginning of Plioeene time. We might also draw a similar inferenee from a consideration of the enormous erosion which took place here before the exeavation of the elasm was begun. The denudation of the Mesozoic system was an incomparably greater work, and yet that denudation eould not have begm until the last strata (the Lower Eocene) were deposited. If these inferences are well founded, we may assign the greater part of Eocene and the whole of Hiocene time for the principal denudation of the Mesozoie, and the Plio. cene and Quaternary for the exeavation of the entire cañon. The pro. portion thus suggested between the portions of the work done and the divisions of time required to aecomplisl them seems very fair and reasonable. But the strongest evidence of all it wonld be almost impossible to recite here in detail. In general terms, it may be characterized as that internal evidenee which appears when a vast array of facts, at first disjointed and without obvious relation, are subsequently grouped aright into a coherent system. Each constituent fact is then seen to admit of one intelligible interpretation and no other; and eaeh sub. sidiary proposition has an overwhelming justification and an evidence of rerity far stronger than any whieh could be summoned if we en. deavored to prove it independently. 
Another question which the geologist asks here is, how happens it that the outer chasm is so broad while the inner one is so narrow? The outer chasin is five to six miles wide and 2,000 feet deep; the inner is about 3,500 feet wide and 3,000 feet deep. Tlue disparity is great. We have seen enongh to say at once that the widening of the outer chasm was effected by the recession of its cliffs. If the corrasion of the cañon went steadily on ward without a halt or respite this disparity demands some explanation. Although we should expect less recession in the clifts of the inner gorge than in those of the onter, we shonld not expect it to be so much less if the only variable concened was length of time. Wo might explain it by assuming the rocks of the immer gorge to be much more obdurate than those above. This is true in part, bnt still the difference in this respect is insufficient. A mneh more satisfactory explanation is found in the supposition that the broad esplanade of the eañon between the upper palisades was an ancient base-level of erosion (page 101). We might imagine that when the Coloralo had cut its channel down to that level, it had reached the limiting depth of eorrasion for the time being. Then for a long period the palisades on either side wasted and receded from the river. At last another epoeh of upheaval set in; the entire platform of the district was lifted sereral thousand feet; the power of the river to eorrade was restored; and with comparative rapidity it sank the immer gorge. This becomes more than a mere guess when we take account of its relation to the general category of facts. 'Thus the great faults attest the fact that such an upheaval did occir; that it occurred, too, just at the time supfosed; and that in amount it was quite equal and probably not more than equal to the amount required. Other evidences might also be produced, but they are too intricate to be discussed liere.*

We leave the Toroweap Valley and the Grand Cañon, regretting that. all its wonderful and instructive subjects should receive such brief notice. letracing our steps up tle 'Toroweap for a distance of about six miles, we at length select one of the great lava streams on the western side. Although quite steep, we may ascend it with the animals and paeks without serious difficulty. At the end of an arduons climb upon the rugged slope, we find ourselves upon the platform of the Uinkiret. Aromd us are the old cinder-cones, most of which are of considerable dimensions. All of them have given rent to floods of basalt, which lave

* I wonld, if space adunitted, be glad to describe the remarkable phenomena presentod in the wall of the inner gorgedireetly across from Vnlean's Throne. Upon the very brink stands the remuant of an old erater (einter-eone) which has been partially mutermined and destroyed by the sapping of tho wall-face. A lateral gorge sets baek into the esplanade from tho river to a distanee of a mile or more. In the wall-fiees are diselosed the dikes throngh whieh the lava came nu. 'Their"strike" is parallel to the conrse of the river, and perpendicular to the conrse of the Toroweap fanlt. 'Two of then protrude from the face of the wall about 600 to 1,400 feet helow the smmmit; others protruele just at the brink. It is extraordinary that none are seen in the depths of the gorge. All of the attendant eiremmstanees are surprising and enrions, and yet it has frequently been noted that basalts habitually seck improbable plaees to ermpt. 
spread out thinly over extensive surfices, but as the number of superposed sheets is considerable in this part of the plateau, the aggregate thickness, though somewhat roughly inferred, must be three or four hundred feet, and occasioually much more. 'There is not much to add to this description. The lava is apparently all of one kind, but some of it much older than other portions. In truth, it soon becomes apparent that the period of volcanic activity was a long one. $\Lambda$ few miles from the point where we attained the summit of the plateau and in a nortlwest direction from it, we come upon the termination of a lava stream which has the appearance of being extremely recent. It looks as fresh as the emanations from Vesuvius or Atna which have cutflowed within the last fifty years. Its surface is intensely black, and only here and there can we perceive that weathering has even impaired its freshness. 'T'wo miles away is seen the cone from which it emauated. The last eruptions from it have alnost destroyed it, and melted down the greater part of its mass.

Skirting the edge of this lava-sheet, we find at the eastern base of Mount Logan a small spring; named the Oak Spring. It is a central point, from which the southern part of the platean may be visited. There is another very small spring high up on the southwestern side of Mount Trumbull, and its waters have been brought down by a wooden pipe to the plain below, to supply the wants of a saw-mill. A third and much larger spring is found on the western side of the Uinkaret. 'These are the only arailable sources of supply, and each may be nsed as occa. sion requires for the examination of different parts of the platean.

It will be necessary here to adrert, with the greatest brevity, to the facts which the Uinkaret presents. Its most conspicuous subject is its rolcanism. Almost as striking a subject is the great Hurricane fault, which forms the western boundary of the plateau. It also presents many other features of interest, but only the briefest allusion to them can be made here.

The lavas of the Uinkaret are all basaltic, and are quite typical of their class. 'They appear to vary but little in their constitution, and, so far as the cursory examination hitherto made indicates, the only differences are such as are ineident to varying conditions under which they solidified after eruption, or to subsequent weathering. But it also appears that the period of volcanic activity has covered a considerable duration of geological time. 'There are old lavas and young lavas; perhaps we may say there are middle-aged lavas. The older lavas are presented in the largest masses, the largest individual coulées. Another noteworthy feature is that the oldest lavas are now found upon the summits of the loftiest portions of the plateau, while the younger lavas are found chiefly on the lower levels. It is well worth studying to see how this comes about. 'The facts and explanation are best presented in the fine mass of Mount Trumbull.

'This mountain is in reality a gigantic butte; that is to sny, a mass of 
sensibly horizontal strata left by the denudation of the same beds from the platform surrounding. It is roofed orer with a ponderous lava-cap, 500 to 800 feet thick. Under this lava-cap are seen in numerous places the horizontal edges of the strata, though the flanks of the mountain are so thickly covered with the débris formed by the disintegration of the basalts at the summit that these strata are for the most part buried. The beds beneath the lava are of Permian age, and it is evident that nearly the whole and possibly quite all of the Permian series remains in the mountain mass. That these basalts are very old is evident at a glance. The evidences of erosion are seen on every hand, and their aspect is strikingly different from that of the younger or middle aged basalts. On the summit of the mountain we find a cluster of old vents, from which a great part at least of these lavas were expelled. They are simply large craters torn down, dissolved and rotted away to their very roots by the ravage of time. It is evident, too, that the lava-cap itself is as a whole a mere remnant of a mass of superposed sheets which once extended much beyond the steep ledge which now limits them all around the mountain. The geologist draws his conclusion very quickly. 'These basalts in the lava-cap) were extravasated at a time when the aspect of the surrounding country was very different from that which is now presented. At that time large bodies of Permian strata, since swept away extended continuously from the edges now exposed in the mountain flanks over spaces far away from it. We cannot indeed affirm that the great denudation had not already begun its havoc in the Permian, but we may be sure that it had not reached nearly its present stage. Mount 'Trumbull then is a remnant of a platform of lava-capped Permian beds, which was once of much greater extent. What was the extent of this platform at the time of the eruptions, we do not yet linow, nor are we likely to linow.

Around the base of the mountain on all sides the more recent craters are thickly clustered. 'The cones are for the most part in an admirable state of preservation; though here and there one may be found which has suffered considerable ravage. About two miles north of the base of 'Trumbull, especially, is an old cone, which has been laid open in such a mamer as to disclose its interior structure very clearly. It is in all respects similar to the cones of the Mediterranean islands and countries. All of these craters were built at a much later period than the lava-cal' of the mountain.

Mount Logan which lies near Trumbull to the southwestward, presents a similar state of affirirs. It is a tabular mass capped with the more ancient basilts and with a great body of Permian beds beneatl. South of Logan is another mass of ancient basalts, overlying Permian stratal. Upon this southern table, however, are planted some well preserved craters which belong to the middle age of eruptions. Chief among these is Mount Emma, whose summit has been used as a primary topograplical station. In general, these more ancient basalts 
1.7.

(n)

and on

in

situs

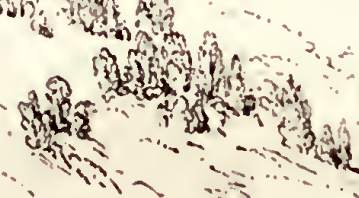

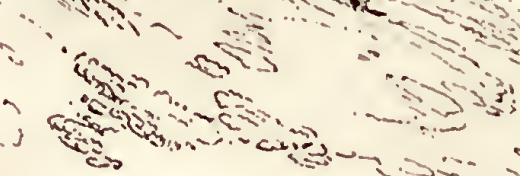

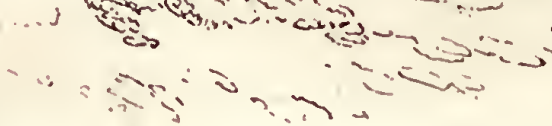

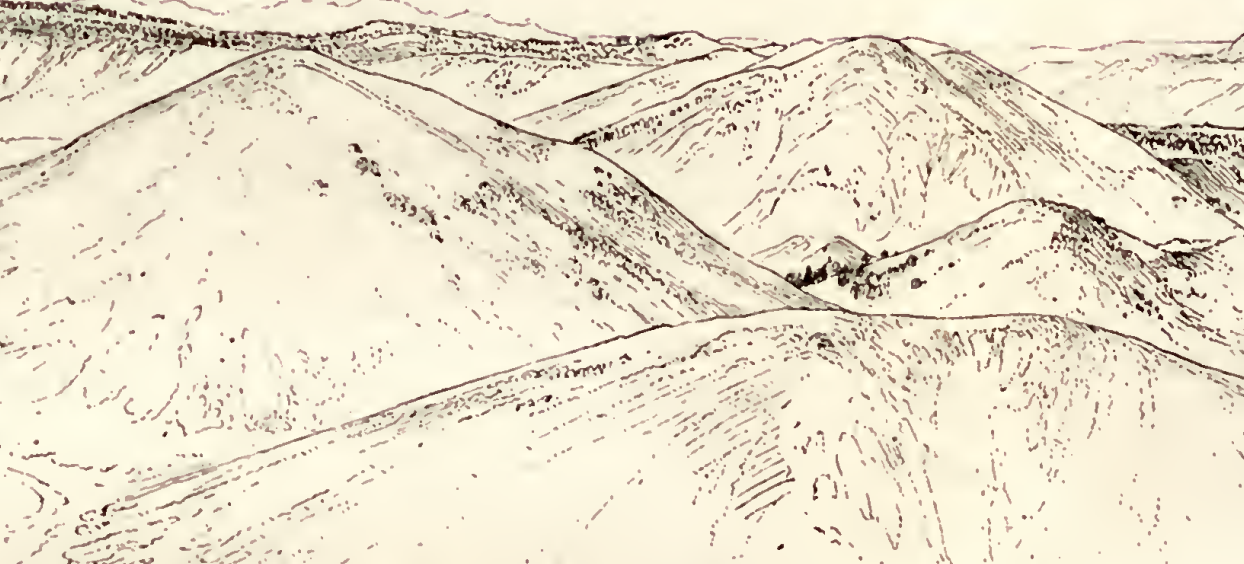

sese
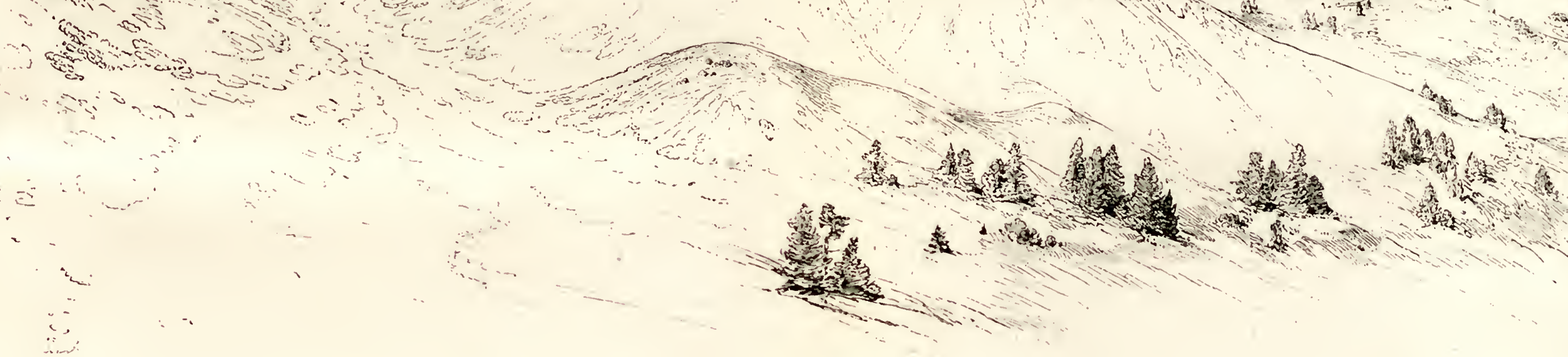

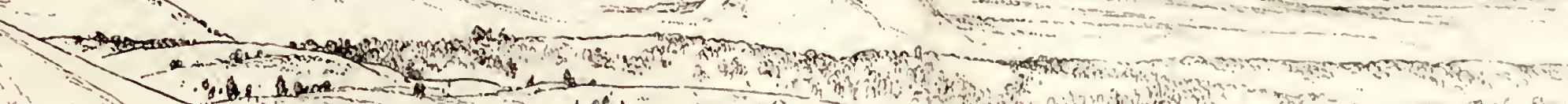

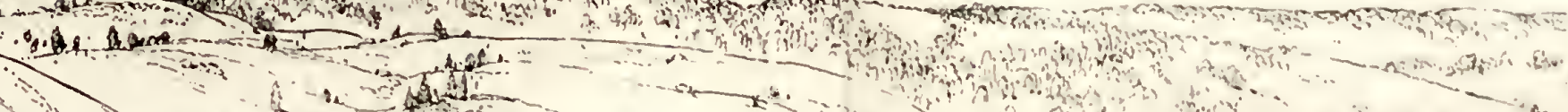
Sold

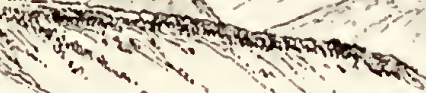

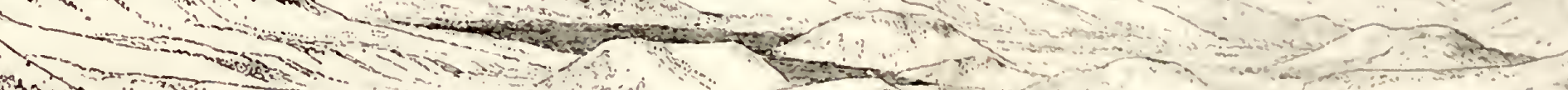
$\lim _{3 \rightarrow \infty}$ and 
descend the Queantoweap) al few miles, and tmrning about we see the eflicets of the fanlt so plainly that a child conld hardly mistake then. Right in the bottom of the valley is the lower branch with a displacement of about 1,300 feet. (Plate XXVIII). On the cliff' to the right is a second smiller" displacement of about 350 feet. Still farther to the right is a third of ibout 700 feet. Beyond the limits of the diagram is a fourth of about 500 feet. 'Twenty-five miles north of the Colorado the branches have disappeared and a single fault remains, with a shear of about 1,800 feet, and this amount continues nearly constant to the northward for a few miles. At lengtl the fault rapidly increases. Seventy-five miles north of the river, and at the point where the Virgen River crosses it, the throw has become colossal. We stand upon the brink of the cliff witl our feet npon the summit of the Carboniferous, and within musket lange, 1,500 feet below, is the Jurassic white sandstone. Most of the Jurassic (S00 feet), the whole of the 'l'rias, which here has numsual thickness $(2,800$ or 2,900 feet), and the whole of the Permian and Permo-Carboniferous $(1,200 \mathrm{or}$ 1,300 feet), overlie the continuation of the strata on which we stand. The total throw is not far from 6,500 feet. Still northward extends the fault, and still it ripidly increases. At length it reaches a maximmm displacement of more than 12,000 feet on the west side of the Markígunt. Contiming north ward it gradually decreases, and finally disappears near the western flank of the 'Tnshar Mountains. The entire lengtl of this fimlt is more than 200 miles. It is throughout its whole extent a primary geological and topograplical feature of the region it traverses.

With regard to the age of the fault we lave some information. It is not probable that all its portions were sheared simultaneonsly, and it is quite certain that its development was very slow and gradual and pro. gressed through a long stretch of geological time. Confining onr attention to that portion extending along the western flank of the Uinkaret, we find that nearly the whole displacement took place after the eruytion of the oldest basalts, for the fault dislocates the most ancient la va beds. Whether some small portion of it may or may not have existed before these eruptions we camot positively say, but no evidence of snch priority has been noted. On the other hand, all the younger lavas, and some, at least, of the middle-aged lavas flowed across the fanlt and have not since been cut by it. But some of the middle-aged lavas appear to have suffered some dislocation. Hence we infer (1), That the age of this part of the Hurricane fault is not older than the beginning of the Pliocene. (2), That the displacement went on in lramony and conjunction with the volcanic activity. (3), 'That for' a long period, historically speaking, it has been quiescent, and no movement has within the historic epoch taken place. (4), 'That the beginumg of the Hurricane fault is older than the beginning of the Toroweap fanlt. 'These conclusious are of great importance in unraveling the history of the Grand Cañon district, for they at once become links in a chain of reasoning which, thongh complex, is very systematic and self-consistent. The funlts are evidences of vertical 


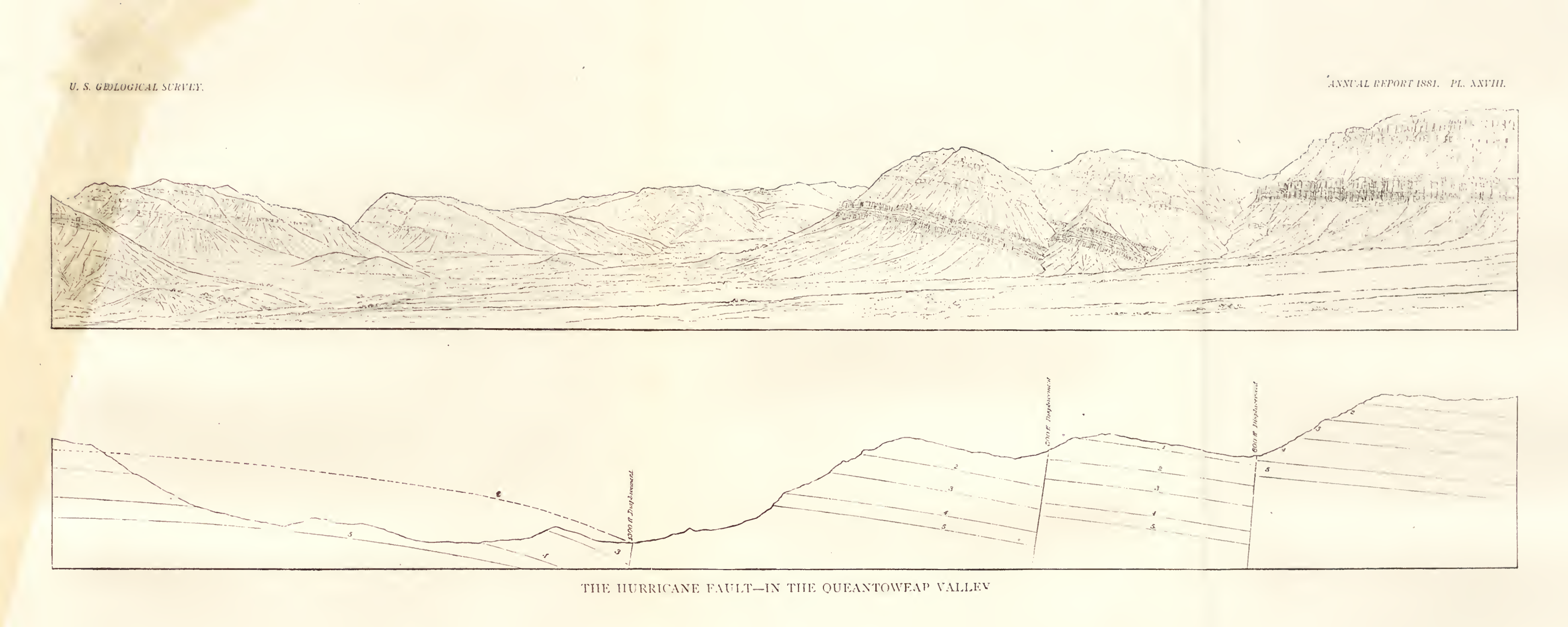




\section{CHA P'T R VI.}

\section{THE ISAIBAB.}

The Kaibab is the loftiest of the four plateans through which the the Grand Cañon extends. It is from 1,500 to 2,000 feet higher than the Kanab Platean on the west, and from 2,500 to 4,000 feet ligher than the Marble Cañon platform on the east. Its superior altitude is due wholly to displacement and not to erosion, for the strata upon its sum. mit are the same as those upon the surfaces of the otlers. 'The up. heaval has produced a sharp fanlt upon the western flank and a great monoclinal flexure upon its easteru flauk. Thronghout its entire platform the npper Carboniferons forms the surface. 'The Kaibab begins at the base of the Vermilion Cliff's near the little village of Paria; its northern extremity terminating in a slender cusp. Steadily widening and increasing very slowly in altitude, it reaches sonth ward nearly a lnn. dred miles to the Colorado River, where it attains a breadth of about 35 miles. Its highest point is about 9,280 feet above the sea, but most of its surface is between the altitudes of 7,800 and 9,000 feet.

When viewed from a distance its summit, projected against the sliy, looks remarkably smooth and level. The slow increase of altitude from north to sonth may be discerned, and yet, in the absence of positive knowledge, it wonld be doubted by the careful observer whether this nirght not be due to perspective, and not real. When we actually visit the platean we find the summit, seeming so smooth when viewed from afar, to be really very rugged. It is scored with a mimtely ramified system of ravines, varying much in depth, but averaging about 300 feet in the heart of the plateau, and much deeper at the flanks. The whole summit is magnificently forest-clad. In this respect it is in strong contrast to the other plateans, excepting, lrowe rer, in a nmeli inferior way, the higher parts of the Uinkaret. The other plateans are formidable deserts; the Kaibab is a paradise. The forests aro due to the superior altitude of the plateau, for the higher the altitude the noister the climate. Through the southern portion of the Kaibab is cut the finest portion of the Grand Cañon. Vast and imposing as is the scenery at the foot of the Toroweap, the scenery of the Kaibab is much more impressive. I propose in the present chapter to describe in familiar lauguage a jonrney from Kanab to the Kaibab, and to the brink of the clasm, where we may contemplate its sublimity. Its geological significance must be discussed in a futmre work.

When the order is given to the party encamped at the little village of Kanab to prepare for the Kaibab, it is obeyed with more than ordinary 
alaerity. From the ehief of the party down to the herders and cooks all look forward to delightful wanderings in a cooler atmosphere, in open forests of noble pines and spruces, in flowery parks and winding arenues of rich verdure; to scenery the grandest of earth, and to communion with Natnre in her noblest and loveliest moods. As we descencl
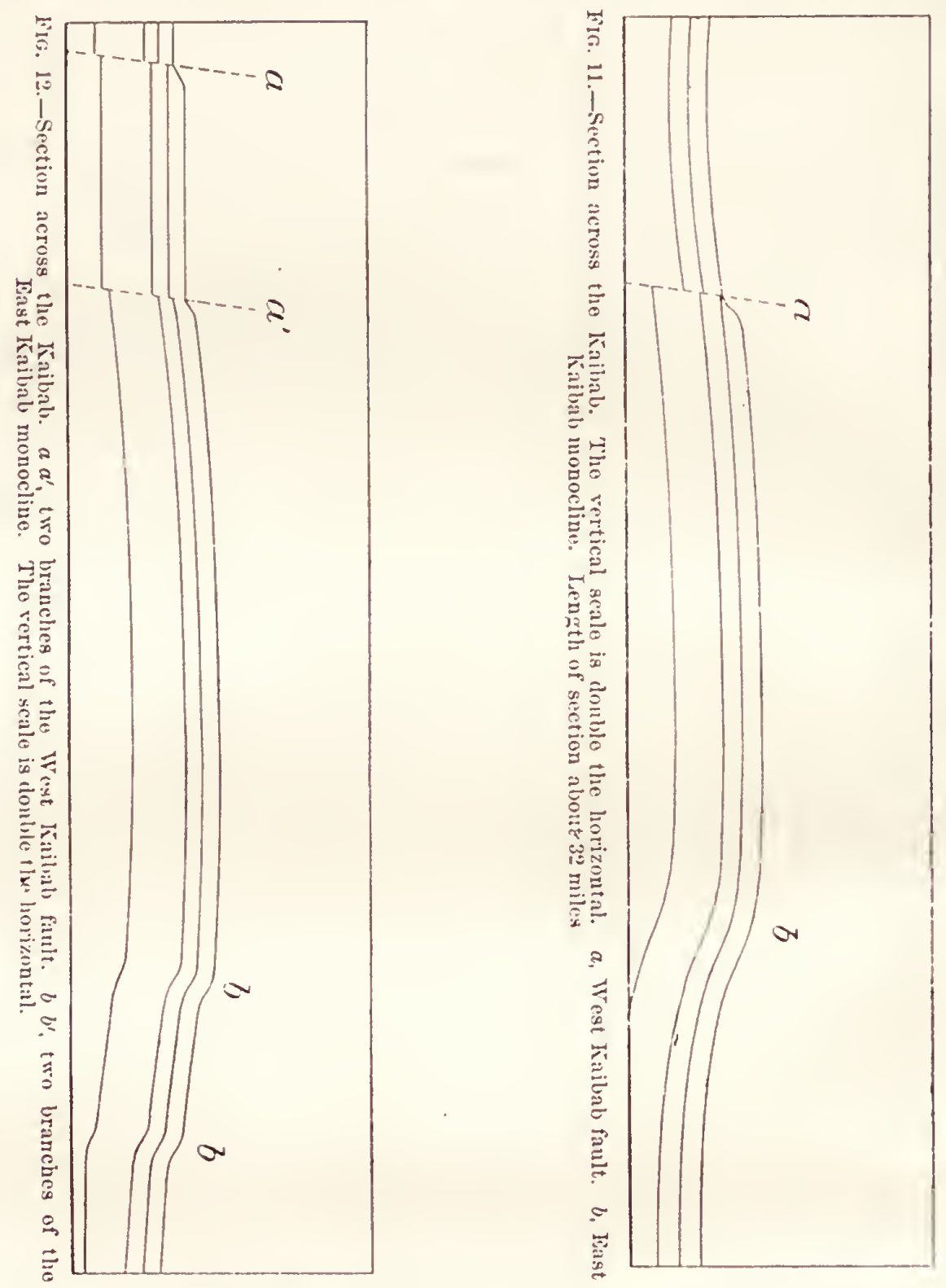

the village street and take a well-known by-path upon its ontskirts, even the poor animals know whither they are going; they have traveled this trail before and renember the long, green bunch-grass and tufted "gram. ma," the lupine and wild oats. They trot along with nimble steps, requiring neither spur to urge nor rein to guide them. Before us is the Permian terrace rising by the gentlest of slopes; through it the Kanab River has cut a wide shallow gap in which stand several pretty little buttes carved sumptuously in the characteristic style of the formation. Beyond it the Carboniferous platform extends sonthward without visi- 


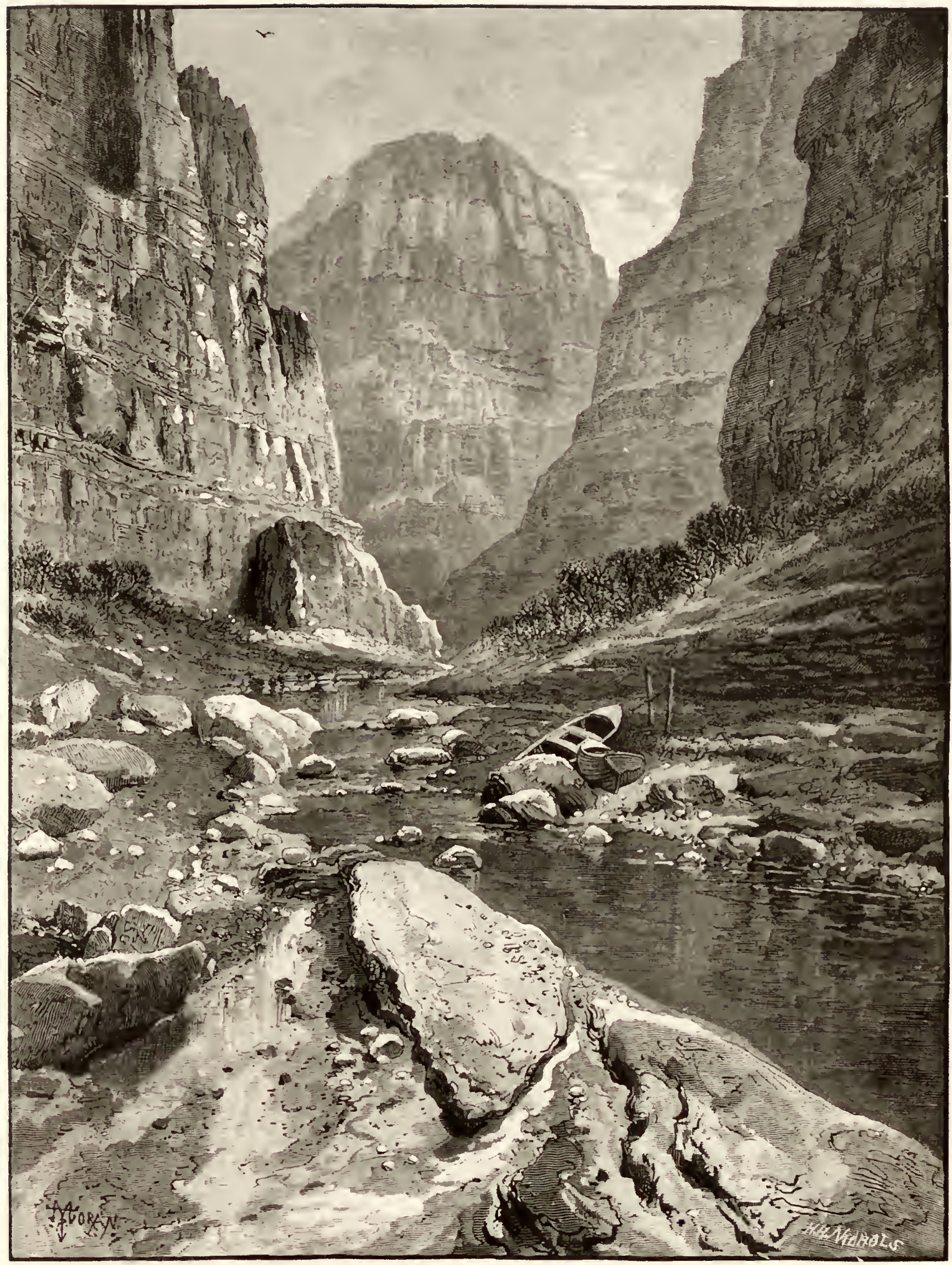


dry. I lave known the temperature of the air to be $110^{\circ}$ at midday, tall. ing to $5 t^{\circ}$ at miduight, withont any general atmospherie distmrbanee or change except that which is due to noeturnal ladiation. Upon theopen lesert the air is almost always still both by day and night. Rarely do the higl winds blow over it in smmmer, and even strong breezes are 111 common except in the vicinity of great cliff's. At night the stilness is profound, and unless there is water or green regetation hard by even the chirping of insects is mheard. The only somnd which breaks upon the ear is the howling of the wolves that prowl about the eamp and follow the tracks of the animals.

The hours roll quiekly past as we move onward in the darkness. At length when the stars betoken the approach of midnight we halt, strip off the paeks and saddles, hobble the animals and tum them loose to browse upon the scanty herbage. As the sun rises we are once nrore on the road. For ten miles from Kamab the trail descends by a hardly pereeptible grade. Thenee it ascends gradnally at a rate of about 150 feet to the mile. From the fifteentl to the twenty-third mile it lies in shallow ravines but at last emerges upon more open ground. As we look back towards the north one of the grand spectacles of the Platean comtry is disclosed to us. It is a view of the great cliffis which bound the sonthern terraces of the High Plateaus rising one above another. Teanly 10,000 feet of strata are exposed erlgewise and ocenpy a line of frontage from 50 to 60 miles in length. It inclndes the stratigraphic series from the base of the Permian to the summit of the Lower Eocene. The view of the terraces from the north, from the brink of the Markagunt or Paunsagunt, is of a very different charaeter from this. There we see only their sloping summits with now and then a fragment of a mural front swung into view obliquely by the meandering course of the line of escarpment. Here the general line of frontage faces us while the terrace platforms are invisible. The view is a distant one but it requires great distance to bring into the field of vision an exposure so vast. At their nearest points the Permian is 15 miles away, the Trias 20, the Jura 35 , and the Locene more than 50. It shonld be observed that we are looking aeross the broad depression or concavity before spoken of, and that there is a gentle slope downwards for 15 miles to the base of the Pernian, which lies 1,900 feet below ns. Notwithstanding the distanee there is no difficulty in distinguishing the different formations, and there would have been none even if we had never before seen the terraces, provided we had become familiar with their several asjects elsewhere; so strongly individualized are their colors and their scmptural forms. The Cretaceons alone is obscure, for in the portions of the terraces now in sight it does not form cliffs but breaks down in long slopes covered with soil and débris. If we were a few miles further west the (retaceous cliffis of the Paria anphitheater would be visible and be as easily determined as the others, but here the Kaibab hides them. Although nearly 10,000 teet of strata are disclosed the summit of the Eocene lies only: 
5,000 to 5,500 feet above the base of the Permian, for in the interval between the two exposures the northward dip of the whole mass has carried down the Eocene abont 5,000 feet.

From every elevated point on the Kanab Platean this magnificent display is in full view. All of the broader geological facts in the stratigraphy and structure of the terraces may be distinctly seen and inter. preted. The increment in thielness of the Mesozoie strata towards the west is very plain. The effect of the great Serier fiult, which comes down from the High Plateans cutting across the terrace platforms and disappearing at the Pipe Spring promontory of the Vermilion Clifts is now visible. By a simple reconstruction, lifting up the thrown side of this fault and gradually depressing the westward extension of the strata until the Eocene is horizontal, we can restore mentally the whole mass to the attitude it lield in Eocene time, and it will require but a slight eflort of the imagination to detect the original configuration whieh determined the present positions of the drainage basins of the Virgen, Kanab, and Paria Rirers. With a neasured base-line extending east and west npon this part of the Kanab Platean and with a fine large theodolite it would be practicuble to make all the measurements necessary for determining the masses and positions of the several stratigraphic members with a degree of accuracy not materially less than conld be obtained by studying them mpon their own gromnd.

A spectacle of this hind is most inpressive to the geologist. It brings into one riew the eoörlinated results of observations made haborionsly by months of travel and inspection in a very broad and rugged field. The great distances through which the eye em reach, the aspeet of elifts towering above and beyond cliffs, the great eunulative altitude thus attained, the immensity of the masses revealed, the bohdness of form, the distinctness of the lines of stratifieation, and especially the brilliant eoloring, subdued indeed, but also refined by the haze, give to the seene a grancleur which has few parallels.

But we turn our backs upon it, and pursue our way, pansing anon to look at it with a reverent enthusiasm. The daylight discloses the western Kaibab wall upon onr left, only five or six miles distant, and our conrse changes from sontheast to sonth parallel to its front. Already we feel the influenees of its long spurs sweeping outward and dying away in the desert platform, and the trail becomes more hilly. Once or twice it takes us down into rivines which are the continuations of the great chasms which cut it to its base and recele far into its mass, winding out of sight in profound depths. Vegetation lias made its appearance all around us, not abundantly, indeed, but sufficiently to contrast with the desolation behind us. Upon the erest of the platean we can see the giant pines and spmuees, and we covet their luxurious shade. Nearer, on either hand, are piñons and eedars, mountain mahograny and mesquite, with many low forms of desert shrubbery. Many species of cactus are seen, the most abundant of which are the opmntias, 
or prickly pears. Of these there are four or five very common species. A large eaetus "orehard" in blossom is a véry beautiful sight, display. ing flowers which, for beanty of form and richmess of eolor, are seldom surpassed by the ehoicer gems of the conservatory. Nor is it less attractive when in the fruit, for it yields a multitude of purple "pears," which are very jniey and refreshing, and by no means contemptible in flaror. There is anotler form of cactus not likely to be forgotten by anybody who has once seen it, and which is rery eommon on the Kanab desert. It is a stout bush, with many branclies, growing from 3 to 6 feet highl. The trunk and branches have a hard, woody eore, and are thickly fringed with rows of strong, sharp spines which present a very ferocions aspect. Altogether it is the most truculent looking member of the regetable kingdom I happen to be acquainted with. Very eonnon, too, are the yueeas, or "Spanish bayonets," which resemble, on a small seale, the noted agave or century plant. Another common species, somewhat resembling the last, bears a ehnster of melon-like seed cases of the size and form of encumbers, which the Indians gather and dry for food.*

At length the trail leads down into "Stewart's Cañon," a rather broad eañon valley deseending towards us from the soutl. Just where we enter it it turus sharply to the west forming an elbow, and, sinking thence ever deeper into the earth through a course of fifteen miles, it opens at last into the heart of Kanab Cañon at a deptl of nearly 3,500 feet. Here at the elbow it is eomparatively shallow. Before reaching the elbow it runs northward close to the base of the Kaibab wall, which rises more than 1,200 feet above its floor, while the opposite or western side is only abont 400 feet ligh. The differenee in the altitudes of the two sides is aeeominted for by the presence of the West Kaibab fanlt, which runs at the foot of the wall throwing down the western side more than 800 feet. The geological relations here are worthy of some study. The presence of the fault is deteeted in a moment. Upon the western side the familiar grey limestones of the Upper Aubrey series form the entire wall. Upon the eastern side the same beds are seen upon the summit more than 800 feet higher than on the western sicle. Beneath them is the hard crossbedded sandstone, and still lower down the brilliant red sandy shales of the Lower Aubrey. Here, too, is seen that curious phenomenon so often presented in conneetion with the faults of this region. As the thrown beds approach the fault-plane they are turned down.

The trail leads southward up Stewart's Cañon with an ascent that is barely perceptible. We become eonscions of increasing altitude indirectly by the barometer and by the ehange in the vegetation. The desert shrubs have mostly disappeared and given plaee to the sernb. oaks and weeds which are the unfailing indieations of a cooler and

* The Mormons find a singular use for this plant. The pounded root, macerated in water, yields a thick liquid which makes a very good substitute for soap. 


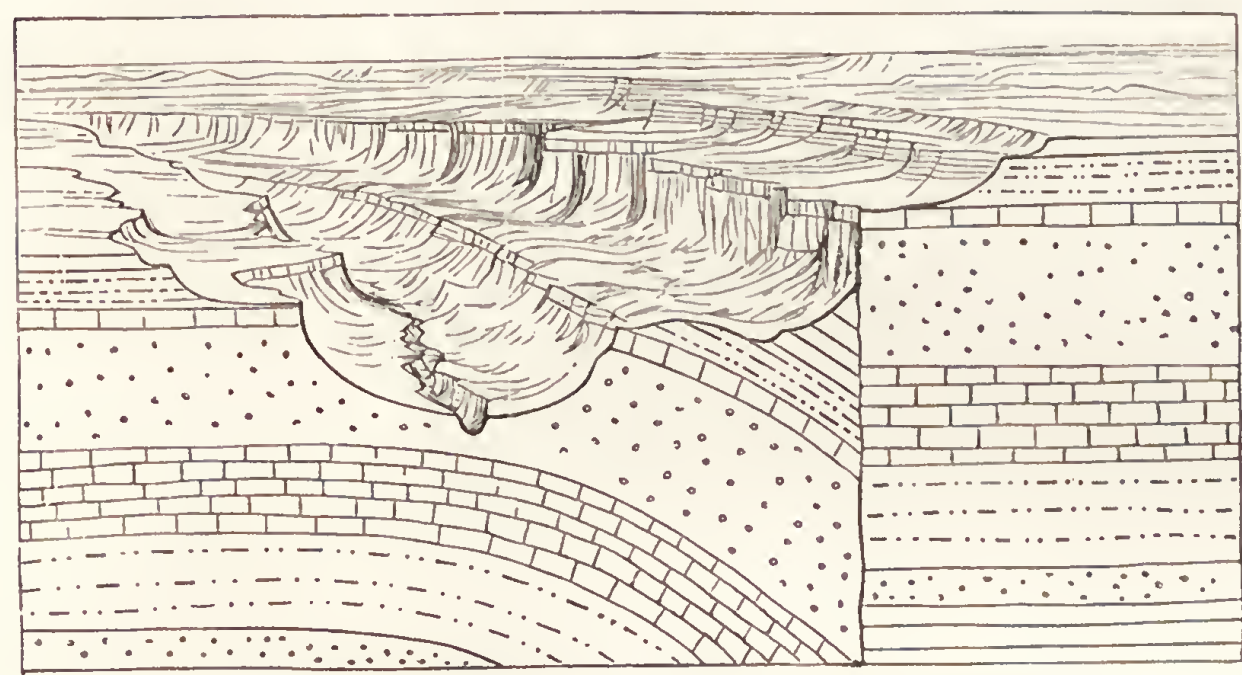

Fig. 13.-A fault with the beds flexed downward on the sunken sido

moister elimate. But the most welcome sight is the close proximity of the yellow pines which stand upon the summit above and eren upon the lower platform which looks down from the western side. As yet they do not grow in the valley bottom. We have not quite reached the Kaibab, thongh it is close at hand-nar, we pass right by its open gates which seem to invite us in with a welcome; for at intervals of a mile or two we perceive upon the left the openings of grand ravines leading up to its platform and the moment we enter any one of them we are within the precincts of the great plateau. Stewart's Cañon is the trunk valley which receives the drainage of a considerable section of the western side of the Kaibab. The large afluents all cone from the east, and none of any importance from the west.

About five miles from the point where the trail enters the valley we reach the first water-a tiny stream eoming down from one of the great ravines and sinling in to the soil a few hmulred yards beyond the mouth. Halting long enough to allow the animals to drink we move onward about two miles further up the valley and make camp. Here there comes ont of the Kaibab wall, about 300 feet above us, a stream of water as lirge as a man's body, which cascades down the rocks into a pool covering half an acre. There is a phenomenon here worth noticing, for it is a prelucle to some very singular fincts of general prevalence throughout this wonderful plateau. Across the outlet of the pool a rude iam has been eonstructed of stones and mud, which may be easily torn open or replaced. When the dam is open a large stream equal to the influx pours out of it, but the whole ontpour sinks within a quarter of a mile. When the dann is closed the water in the pool rises about 15 inches and there is no outflow. All the water which enters the pool then sinks along the newly submerged margin. A stream of that size anywhere else in the Plateau conntry would ordinarily lun eight or ten miles, and in a moist country would run much further. The sudden sinling of 
streams is by no means rare, but is generally exceptional. On the Kaibab it is the rule. Upon all its broad expanse there is nothing which can be properly called a brook or a living stream. About a dozen springs are known, but their waters in erery instance sink in the earth within a few hundred yards of their somrces. And the "Big Spring" in Stewart's Cañon yields several times as much water as all the others pnt togother. With this forelinowledge the prospects of water supply upon the Kaibab might seen disconrging; but we shall not snffer for the want of it.

Althongl the smin is still high when the Big Spring is reached nothing will be gained by prolonging the day's march, and it is well to take a look at the surroundings. In some way, withont knowing exactly when and where, we seem to have gotten into the Kaibab; for aromil us is the sylvan scenery and a rolling conntry traversed by many valleys and ravines. True they are not the finest types, but when we recall the desert we have just left this place looks like a paradise. The barometer shows a considerable altitnde, 7,850 feet, and the air thongh warm is not oppressive. As we approached the platean from the lesert and saw its battlenents towering grandly in the distance and becoming hourly more grand, its level parapet retreating into indefinite distance in either direetion, it never occured to us that we might be spared the arduons strug. gle of scaling the wall, or, as a still more ardnous alternative, the foreing of a rough passage throngh some narrow ravine for many miles. Yet we have reached this spot by a ronte as easy as an old-fishioned tminpike. In truth. the confignration of the sontheru part of the Kaibab conld not be discerned as we approached it from the north. But putting together the observations of the journey it now becomes apparent that the smrace of the Kanab Platean rises quite rapidly towarls the south, while the Kaibah gains in altitude much more slowly. Opposite our last camp the difference in the altitudes of the two plateaus is abont 2,300 feet. Here it has greatly diminished, and the passage from one to the other is ncw partly by a very gentle inclined plane and partly by a fanlt. Fifteen miles further south the fault vanishes or becomes insignificant, and the passage is by a long slope.*

Resmming in the morning the ronte up Stewart's Canon, a half-hour's ride brings us to an abandoned saw-mill. Here the trail leaves the valley which we have followed for ten miles and turus up into a large ravine coming from the east or sontheast. It is much narrower than Stewart's Cañon, with very abrnpt and ahmost precipitons walls abont 600 feet

*It may be remarked here that every fault in the distriet is accompanied with a corresponding break in the topography. A cliff or steep slope is produced by it. I do not recall an instance where the lifted beds are planed off by crosion, so as to make a continuous level with the thrown beds. The eliffs generated bs displacement have a character of their own which the experieneed observer distinguishes quickly and confidently from eliffs of crosion. These characteristic brealis iu the topography often botray a fault in localities where it would otherwise have been passed over unnoticed and unsuspected. 
high. The traveler in the Platean province learns to dread the neces. sity which compels him to thread a deep gorge or cañon unless he knows beforehand that there is a practicable and easy trail throngh it. If it is dry it is almost certain to be obstructed by fallen fragments and thickly set with scrub, its bottom scoured into rongh gullies by the sudden floods; and half the time it will be necessary to mount the steep talus and thread it. If it carries a living stream the way is still worse, for in addition to the foregoing difficulties there are dangerons quicksands, impenetrable thickets of willows and thoruy bushes, and the stream meanders from wall to wall. Unless there is a good trail the traveler will usually prefer to monnt the cliff if a break can be found in it and seek the mesa above, and thus by a single struggle get rid of the miseries below. Not so the ravines of the Kaibab. Like the paths trodken by the pilgrims in the Delectable Mountains, "their ways are pleasantness and all their paths are peace." The ravine we enter is bnt a fair specimen of a vast number of them which corer the whole broad surface of the platean with an infinite network of ramufications. Its bottom is corered with a carpet of grass and flowers growing rankly in a smooth firm soil free from rocks and undergiowti. Here and there a climmp of aspens or noble pines grow in the way, but offer no obstacles to progress. It is like riding throngh a well-kept park or an avenue shaded by ancient trees. And now the effect of the absence of streams becomes manifest. Not only are there 110 perennial brooks, but there are $n$ o indications that even in the time of heary rains or of melting snow any notable amomnt of water ever lmus in these clanmels. Yet the Kaibab is a moist region. In smmmer the rains are frequent and in winter the snow lies deep. Horses cannot winter there and the wild cattle and deer, late in October, abandon it and seek the lower regions aromnd its flanks. In all other plateans or mountain ranges of equal mass and altitude and with equal precipitation there are many goodly streams and even large creeks fed thronglont the snmmer by numberless eopious springs; and when the snows melt these streams becone raging torrents. Bnt so rare are the indications of rmning water on the Kaibab even in times of melting snow, or of vernal rains, that whenever we find a "wash" we look at it with surprise as if it were a strange phenomenon demanding special explanation. But the very absence of these traces of running water constitutes one of the greatest charms of the Kaibab, for every ravine is as smooth as a lawn and carpeted with a turf of monntain grass, richly decked with flowers of rare beanty and luxuriance.

The great trees grow ehiefly upon the main platform above ns. Except in the highest part of the platean they are mostly the yellow pine (Pinus ponderosa), but large spruces are also common (Abies grandis. A. Engelmanni). Upon the flanks of the ravines they also grow, the pines npon the northern or sunny side, the spruces upon the opposite. In the valley bottom they grow scatteringly, and for the most part leave 
it quite open. Contrasting finely with these are the aspens (Populus tremuloides) with their white trunks and pale green foliage. Thronglıont the greater part of the platean these three genera comprise all the arboreal forms that oceur. But upon its borders we also find cedars, monntain nuhogany, and piñon (Juniperus oceidentalis, Cereocarpus ledifolius, and Pinus edulis), the latter, though elassed as a pine, differing greatly from the more typical forms of the renus.

The ravine, where we enter its month, is abont 600 feet in deptl. The ascent is by a very easy grade, averaging abont 100 feet to the mile. As we progress it becomes slallower, but not so rapidly as the grade miglit indicate, for the platean summit also rises thongl at a lower grade towards the east. 'The course is a crooked one, but none the less agreeable on that account. Every traveler on foot ol horseback has probably observed how tiresome and monotonous the road becones when le can see it stretching away before lim for many miles, and how charming the diversity when it wanders hither and thither. It matters not if the successive vistas are as mueh alike as two turus of a kaleido. seope, there is always an inpatience to see what is beyond the next turn. So it is here. The suceessive scenes are much alike, or change by insensible degrees, but the same general view is presented in ever varying detail, and its subject matter is always delightfit.

It is difficult to say precisely wherein the clarm of the sylvin scenery of the Kaibab consists. We, who through successive sminers have wandered through its forests and parks, have come to regard it as the most enchanting region it has ever been our privilege to visit. Surely there is no lack of beantiful or grand forest scenery in Anerica, and it is a matter of taste what species of trees are the most pleasing. I'robably few people wonld select the conifers and poplars as the highest types of arboreal beanty. I suspect that the charm consists in influences fir more subtle than these outward forms. The delieions elimate, neither cold nor hot, neither wet nor excessively dry, but always exhilarating, is a findamental condition by virtue of which the body and mind are bronght into the most susceptible mood. The ease with which we move from place to place, the absence of all anxiety or care for the three great requisites of camp life, fuel, water, and grass, are accessory conditions. The contrast of the desert with its fatigne, its unuberless discomforts and privations, is still another. But the scenery is also very beautiful in itself. The trees are large and noble in aspect and stand widely apart, except in the highest parts of the pla. teall where the spruces predominate. Instead of dense thickets where we are shut in by impenetrable foliage, we can look far beyond and see the tree trunks ranishing away like an infinite colonnade. The gronnd is unobstructed and inviting. There is a constant succession of parks and glades-dreany avennes of grass and flowers winding between sylvan walls, or spreading out in broad open meadows. From 
Jnne until September there is a display of wild flowers which is quite beyond description. The valley sides and platforms above are resplendent with dense masses of scarlet, white, purple, and yellow. It is noteworthy that while the trees exhibit but few species, the humbler plants present a very great number, both of species and genera. In the upper regions of the High Plateans, Mr. Lester F. Ward collected in a single season more than 600 species of plants, and the Kaibab, though offering a much sinaller range of altitude and climate, would doubtless yield as rich a flora in proportion to the diversity of its conditions.

At a distance of about eight miles from its mouth, the ravine we have chosen has become very shallow, with gently sloping sides. At length we leave it and ascend its right bank to the npper platform. The way here is as pleasant as before, for it is beneath the pines standing at intervals varying from 50 to 100 feet, and upon a soil that is smooth, firm, and free from undergrowth. All is open, and we may look far into the depths of the forest on either hand. We now perceive that the surface of the platean mulnlates with rolling hills and gently depressed vales. These valleys are the ramifications of the drainage channels. They are innumerable and cover the entire surface of the platean. The main chamels all deepen as they approach the elges of the platem and often attain considerable depth, becoming at the same time preeipitons. The deepest are those which emerge near the elbow of Stewart's Cañon and north of that point. These attain depths exceeding a thonsand feet. The ravines which descend towards the castcrn flank of the platean terminate in a different mamer. In the interior parts of the platean these drainage valleys are all shallow, rarely exeeeding $300 \mathrm{or}^{\circ}$ 400 feet in depth, and seldom abrupt.

After two or three niles upon the smmmit, the trail descends into another valley, whose course we follow npward for abont seven miles. At the distance of about twenty miles from Stewart's Cañon, we find that we have gained about 1,200 feet of altitnde, and that the regetation has ehanged its aspect somewhat. The pines, though still abundant, are now in the minority, and the spruees and aspens greatly predominate. The spruces form dense thickets on either hand, which nothing but the direst necessity would erer induce ns to enter. Of this genus there are several species, virying mncls in liabit. The great firs (Abies grandis, $A$. Engelmanni) are exceedingly beautiful on account of their sumptuous foliage. But the most common species is a smaller one (A. subalpina), with a tall and straight trunk, its branches spreading only five or six fect. These trees cluster so thickly together that a passage through them is extremely difficult and sometimes impossible. But we are not constrained to attempt it, for they seldom grow in the valley bottoms. Again we leave the ravine, and winding abont among the hills, passing from glade to glade, we at length find ourselves upon the summit of a long slope, which descends rapidly into a great park, the largest on the Kaibab. It has received the name of 


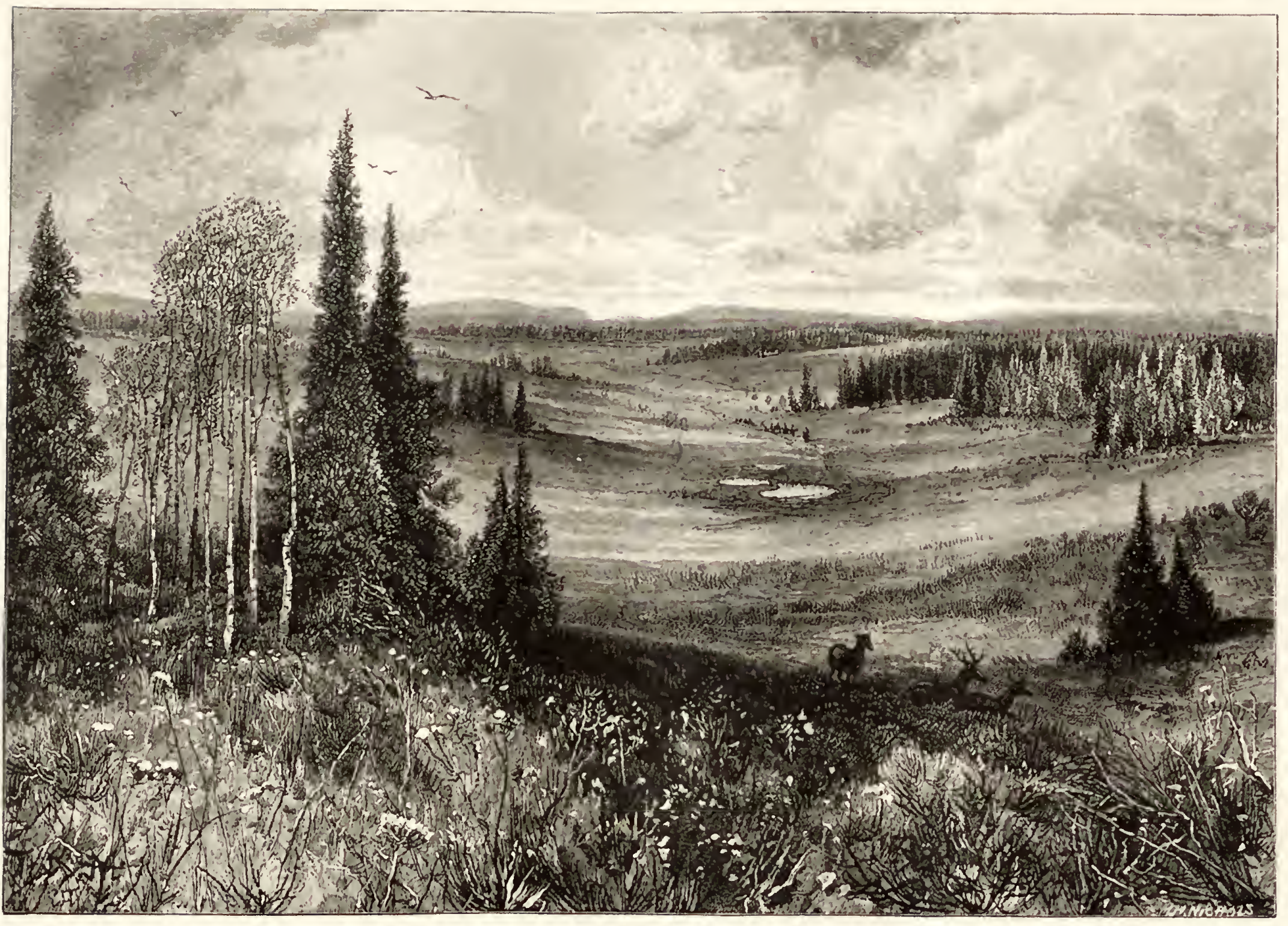

DEMOTTE PARK. 


\section{DE MOTTE PARK.}

Its length is about ten miles, its average width about two miles. It is a depressed area in the heart of the platean and is on every sicle girt about by more elevated ground rising by strong slopes 300 or 400 feet above its floor. The borders and heights abore are densely forest-clad, but not a tree stands within the park itself. Deseending into its basin and proceeding sonthward about two and a half miles, we reach a little spring where we make camp. The distance from the Big Spring to Stewart's Cañon is about 26 miles by trail.

De Motte Park is eminently adipted to be the base of operations in a campaign of geological investigation upon the sonthern part of the Kaibab. It is a central locality from which we may radiate in any direction to the bounds of the platean. Here the great bulk of the supplies may be deposited, and from the supply camp we make jomrneys with light packs for one, two, or three dars, as it may suit our convenience, and to it we may return to fit out for another short trip. The eireumstances which make the park so advantageous in this respect are worth reciting.

Notwithstanding the open character of the forest there are two difficulties in the way of travel on the Kaibab. The first has already been mentioned, scarcity of water. We know of about a dozen sinall springs, some of them conveniently located for the purposes of the explorer, others not. There is, however, another source of water supply which will be described presently. The second difficulty is the danger of getting lost and bewillered in the forest. Thismay seem to be a singular sonrce of danger for an explorer, who of all men is bound to know his exact whereabouts at every step). But if he were to visit the Kaibab with that easy confidence and without a guide he would probably learn a severe lesson in less than a fortnight. The young Mormon herders who range over this region, and who follow a trail with the keen instincts of Indians, and with more than an Indian's intelligence, dread the mazes of the forest until they come to know them. Even the Indians who live and hunt there during the summer and autumn have sad tales about comrades lost when the snows came early and buried the trails so that they conld not be followed. The bewildering character arises from the monotony of the scenery. There are hundreds of hills and gulches, but they all look alike. There are no landmarks except trees, which are worse than none at all. If you enter a ravine for the second time at a point other than that at which you first entered it you would probably fail to recognize it. As with the faces of the Chinese, no conscientious white man would be willing to swear that he had ever seen any particular one before. Yet the riddle of the Kaibab is soon solved, and, once read, all danger is over. If the traveler is lost there is an infallible clew. He must go at once to De Motte Park. But how shall he find the way? If he has reason to 
suppose that he is within a dozen miles of it he has only to enter a main ravine and follow it to its head. This, however, does not apply to the portions of the plateau which lie more than five miles north of the park. The way may be long, but is easy and sure. A few ravines fade out before reaching the near neighborhood of the park. In that event take the nearest one on the right or left. All of them head upon the snmmit which looks down into the park. It is necessary, however, to keep to the main ravine and avoid its minor tributaries, and there is a criterion by which it maly be distinguished. At the confluence of a lateral ravine the grade of the main ravine is always the less of the two.

Although this may seem to be nothing more than a trival bit of woodcraft, it really illustrates an important fact-the drainage system of a large portion of the Kaibab. The stndy of this drainage system will shed some light npon the geological history not only of the platean itself, but of the region adjoining, and of the Grand Cañon.

The thouglit which must be predominant in the mind of cne who fo: the first time enters the Kaibab is of the Grand Cañon. The fime of its grandeur is world-wide, and the desire to see it as it is grows stronger the nearer he approaches to it. This longing must be at least tempered if not wholly satisfied before the mind is in the humor to contemplate anything else. Our first expedition, then, shall be to the brink of the great abyss.

As the sun is rising and before his beams have penetrated to the bottom of the park we are on the way. On either hand is the forest, covering the slopes and the heights above, but ending snddenly at the foot of every incline. Before us to the southward stretches the open field with hardly an undulation. Six or seven miles away we can see the sylvan walls approach each other, leaving a narrow gateway between the tall spruces where the surface of the ground for a moment is sharply projected against the sky. The scene is, on the whole, a very attractive one. There is a great wealth of vegetation, somber indeed, and monotonous, but the darkness of the tone is suggestive of depth and richness of color. The only alleviating contrast is between the smooth expanse of the park and the myriads of sharp spikes which terminate the tree tops. The spirit of the scence is a calm, serene, and gente one, tonched with a tinge of solemnity and melancholy.

Abont a mile from camp we came upon an object worthy of attention. It is rather a deep depression in the earth about 200 feet across and very nearly circular. Within it is a large pool of water. Its depth below the valley floor may be about 40 feet, and the depth of the water 5 or 6 feet in the middle. It is a fain specimen of a frequent oceurence upon the Káabab. I have never seen them elsewhere, and the explanation is difficult. The interest lies in the mystery of their origin. In every day's ride we usually find three or four of them and sometimes more. Some of them contain water, but the majority do not. Some hold water throughout the year, some only in the early summer or until 
autumn. They vary in size and depth very considerably. Some are as narrow as 20 feet; some are 300 to 400 feet across. The deptlis vary from a yard or two to a hundred feet. The form is crater-like-always approximately circular. They do not appear to occur under any special set of conditions. They are fonnd as often upon the platforms as in the valleys and are not uncommon upon the slopes of the ravines. In a few instances traces may be seen of rain gullies or washes leading into them, but not often, and none have ever been noted leading out of them. Whatever ruming water may enter then sinks within their basins; but it is certain that many of them rarely receive any running wates In the cases of those which do the wonder is that they donot soon fill up with sand and silt, for the water generated by hoary rain storms or by melt. ing snows, when sufficient in rolume to run in a stream, is always thick with mud. 'The scarcity of running water on the Kaibab has been mentioned. Yet the precipitation is comparatively great and the evaporation small. It is apparent that all the water which falls upon its vast expanse, witl the exception of a slight percentage evaporated, nust sink into the eartl, where it is doubtless gathered in subterranean drainage channels which open in the profound depths of the great amphitheaters of the Grand Cañon. In those depths are large creeks of perennial water issuing from the openings of those underground passages. This implies a systen of subterranean rivulets, but it is not more wonderful than the endless caverus in the limestones of Kentucky and Indiana, and it is probably not upon so large a scale nor so greatly ramified. It also argues a high degree of permeability both in the npper strata and in the overmantling soil. The water sifts throngh then as easily as through sand, and rarely gathers into streams even in the most copious showers or most rapid melting of the snow. Whether these "lagoons" and "sink-holes," as we termed them, are the openings of pipes leading down into the subterranean rivers and kept open by a gradual solution of the linestone, it is diflicult to say. There are some diffisultes in the way of this theory.

Moving rapidly soutlward, at length we reach the Sylvan Gate at tlie lower end. Passing through we immediately find ourselves at the head of a second park very similar to De Motte's, but smaller, having a length of nearly three miles. It is named Little De Motte Park, and the Sylym Gate occupies a divide between the two. It contains a large lagoon holding stagnant water. There is a chain of these parks reaching from the northern end of De Motte's southward, a distance of $2 \tilde{5}$ miles, separated only by necks of forest.

Our first objective point is a spring situated in one of the large ravines which head in the heights overlooking these two parks. Without some foreknowledge of the way to reach it, or without a guide, it would be impossible to find it, and the same is true of any other spring on the sumnit, but with this foreknowledge we seek the southwestern border of Little De Motte and enter the timber. During half an hour there is 
a miserable struggle with fallen trees and thick set branches of spruce and aspen, but at length the heights are gained, and we descend into a slallow ravine where the way is once more open. The winding glade with smootl bottom richly carpeted with long green grass, aglow with myriads of beantiful blossoms is before us, and the tall trees are on either hand. Soon it leads into a larger one, and this into another, nntil at last the main ravine is reached. Very sweet and touehing now are the inflnences of nature. 'The balmy air, the dark and somber spluces, the pale green aspens, the golden shafts of smnlight shot throngh their foliage, the velvet sward-surely this is the home of the woolland nymplis, and at every turn of the way we can funcy we are abont to see them flying at our approach, or peeping at us from the flowery banks.

By laalf-past ten the spring is reached. Next to the Big Spring, in Stewart's Cañon, it is the largest on the summit of the platean. Here, too, is the only semblance of ruming water, for the stream flows a little more than half a mile before it sinks. The water is cold and delieions. It has a faint whitish cast like that which would be prodnced by putting a drop or two of milk into a bueket of pnre water. I presume it is caused by a tine precipitate of line. We called it the "Milk Spring." Pansing here for a hastr lmuch, and to fill the kegs (for to-night we may make a "dry" camp), we pnsl on. We climb out of the ravine, and in faet we only came here to obtain water, as it is the only place near to the point of destination at which water can be procured. The route now becomes more rugged, leading across ravines and over intervening ridges, crossing the grain of the country, so to speak. Bnt it is not diflicult, for the pines have taken place of the spruces, and where the pines predominate the forest is very open. For eight miles from the Mlilk Spring we continue to cross hills and valleys, then follow a low swale shaded by giant pines with trunks three to four feet in thiekness. 'The banks are a parterre of flowers. On yonder lillside, beneath one of these kingly trees, is a spot which seems to glow with an unwonted wealth of floral beanty. It is searcely a hnndred yards distant; let us pluck a bouquet from it. We ride up the slope.

The earth suddenly sinks at our feet to illimitable depths. In an in. stant, in the twinliling of an eye, the awful scene is before us. 


\section{CHA P'TER VII.}

\section{POINT SUBIAMT.}

Wherever we reach the Grand Cañon in the Kaibab it bursts npon the vision in a moment. Seldom is any warning given that we are near the brink. At the Toroweap it is quite otherwise. 'There we are notified that we are near it a day before we reach it. As the final march to that portion of the chasm is made the scene gradnally develops, growing by insensible degrees more grand nutil at last we stand npon the brink of the inner gorge, where all is before us. In the Kaibab the forest reaches to the sharp edge of the eliff and the pine trees shed their cones into the fathomless depths below.

If the approach is made at random, with no idea of reaching any particular point by a known ronte, the probabilities are that it is first seen from the rim of one of the vast amphitheaters which set back from the main chasm far into the mass of the platean. 1 t is such a point to which the reader has been bronght in the precerling chapter. Of conrse there are degrees in the magniturle and power of the pictmes presented, but the smallest and least powerful is tremendons and too great for comprehension. The scenery of the amphitheaters far surpasses in grandeur and nobility anything else of the kind in any other region, but it is mere by-play in comparison with the panorama displayed in the heart of the cañon. The smpreme riews are to be obtsined at the extremities of the long promontories, which jut ont between these recesses far into the gulf. Towarls such a point we now direct our steps. The one we have chosen is on the whole the most commanding in the Kaibab front, though there are several others which night be regarded as very nearly equal to it, or as even more imposing in some respects. We named it Point Sublime.

The route is of the same character as that we have already traversedopen pine forest, with smooth and gently rolling ground. The distance from the point where we first touched the rim of the amphitheater is about five miles. Nothing is seen of the chasm nntil abont a mile from the end we come once more npon the brink. Reaching the extrene verge the packs are cast off and sitting upon the edge we contenplate the inost snblime and awe-inspiring spectacle in the world.

The Grand Cañon of the Colorado is a great innovation in molern ideas of scenery, and in our conceptions of the grandeur, beanty, and power of nature. As with all great inmovations it is not to be comprehended in a day or a week, nor even in a month. It must be dwelt upon and studied, and the study must comprise the slow acquisition of 142 


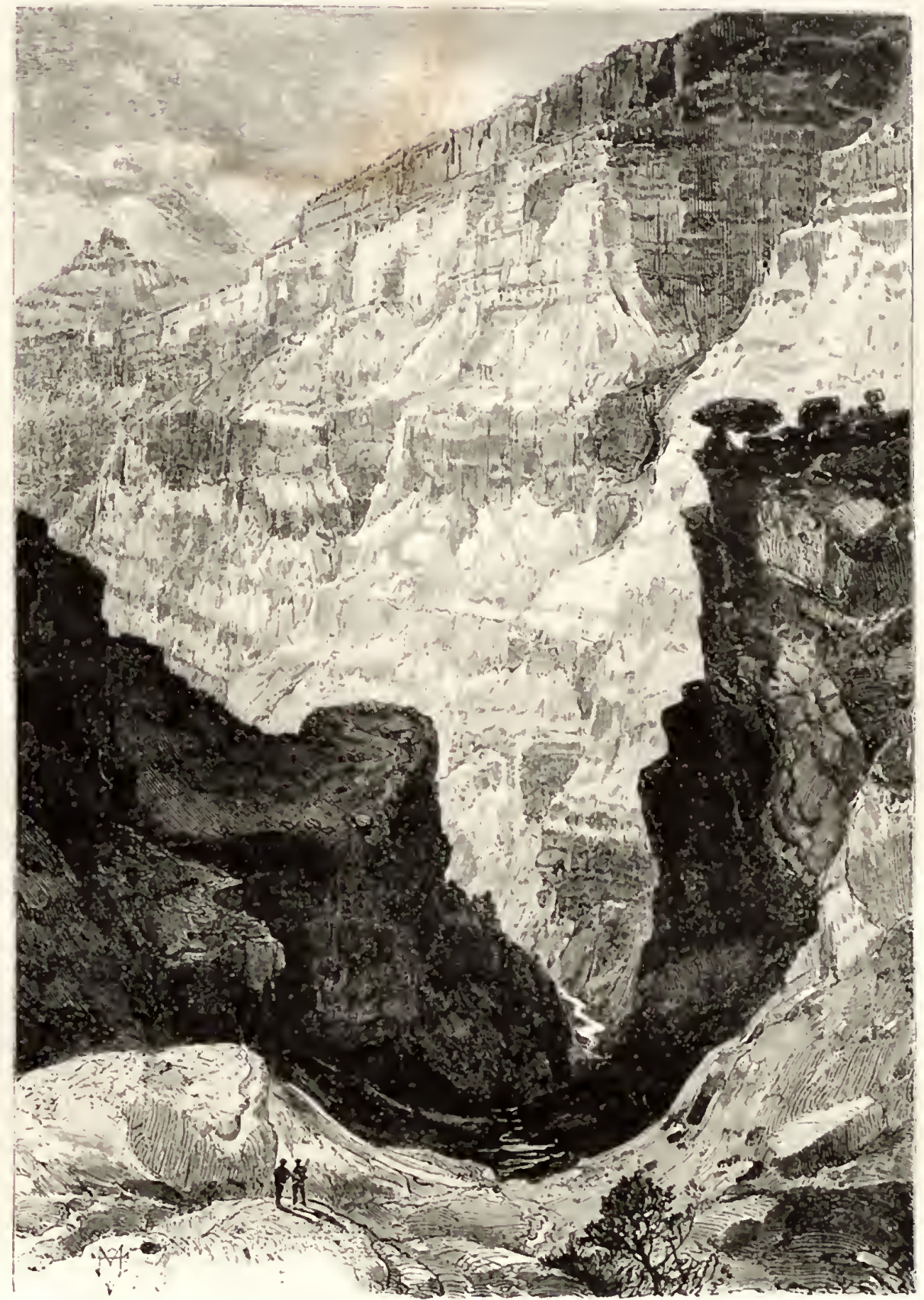

14.-A lateral amphitheater of the second order.

the meaning and spirit of that marvelous scenery which chancterizes the Plateau country, and of which the great chasm is the superlative manifestation. The study and slow mastery of the influences of that class of scenery and its full appreciation is a special cnlture, requiring time, patience, and long familiarity for its consummation. The lover of nature, whose perceptions have been trained in the Alps, in Italy, Germany, or New England, in the Appalachians or Cordilleras, in Seotlaud or Colorado, wonld enter this strange region with a shock, and dwell there for a time with a sense of oppression, and perhaps with horror. 


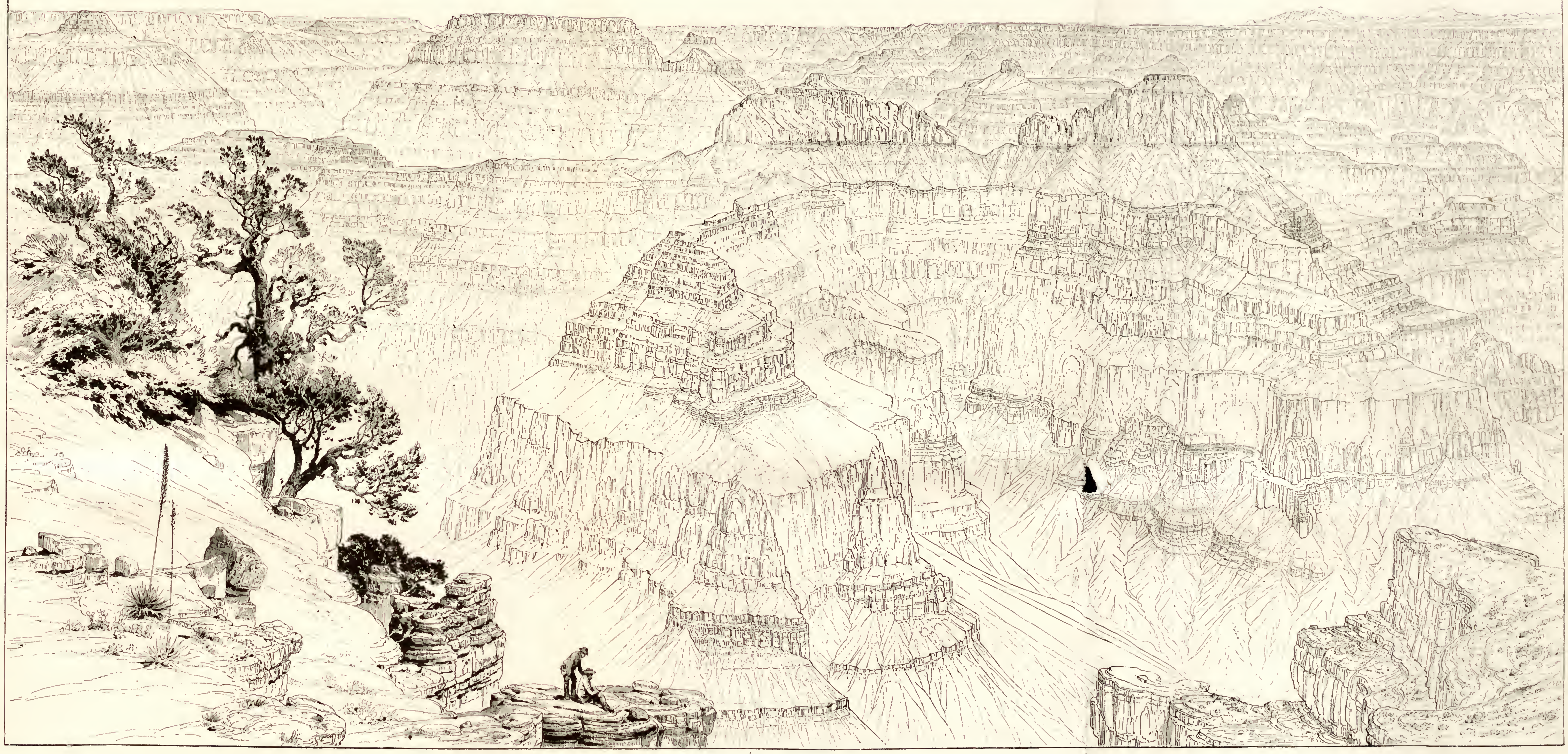

THE PANORAMA FROM POINT SUBLIME-LOOKING RAST. 
Whatsoever things lie had learned to regard as beautiful and noble he would seldom or never see, and whatsoever lie might see would appear to him as anything but beautiful and noble. Whatsoever might be bold and striking would at first seem only grotesque. 'The colors wouk be the very ones he lad learned to slum as tawdry and bizarre. The tones and shades nodest and tender, subdued yet rich, in which his funcy had always taken special delight, would be the ones which are conspicuously absent. But time would bring a gradual change. Some day he would suddenly become conscious that outlines which at first seemed harsh and trivial have grace and meaning; that forms which seenred grotesque are full of dignity; that magnitudes which liad added enormity to coarseness liave become replete with strength and even majesty; that colors which liad been esteened unrefined, inmodest, and glaring, are as expressive, tender, changeful, and capacions of effects as any others. Great immovations, whether in art or literature, in science or in nature, seldom talie the world by storm. 'They must be understood before they can be estimated, and must be cultivated before they can be understood.

It is so witlı the Grand Cañon. The observer who visits its commanding points with the expectation of experiencing forthwith a rapturous exaltation, an ecstacy arising from the realization of a degree of grandeur and sublimity never felt before, is doomed to disappointment. Supposing lim to be but little fumiliar with platean scencry, lie will be simply bewildered. Must he therefore pronounce it a failure, an overpraised thing? Must he entertain a just resentment towards those who may have raised his expectations too high? The answer is that subjects which disclose their full power, meaning, and beauty as soon as they are presented to the mind have very little of those qualities to disclose. Moreover a visitor to the chasm or to any otler famous seene must neces. sarily come there (for so is the human mind constituted) with a picture of it created by his own imagination. He reaches the spot, the conjured picture vanishes in an instant, and the place of it must be filled anew. Surely no inagination can construct out of its.own material any pieture having the remotest resemblance to the Grand Cañon. In truth the first step in attempting a description is to beg the reader to dismiss from lris mind, so far as practicable, any preconceived notion of it.

Those who have long and carefully studied the Grand Cañon of the Colorado do not liesitate for a moment to pronounce it by far the most sublime of all earthly spectacles. If its sublimity consisted only in its dimensions, it could be sufficiently set forth in a single sentence. It is urore than 200 miles long, from 5 to 12 miles wide, and from 5,000 to 6,000 feet deep. There are in the world valleys which are longer and a few which are deeper. There are valleys flanked by summits loftier than the palisades of the Kaibab. Still the Grand Cañon is the sub. limest thing on earth. It is so not alone by virtue of its magnitudes, but by virtue of the whole-its ensemble. 
The eommon notion of a eañon is that of a deep, narrow gash in the earth, with nearly vertical walls like a great and neatly cut trench. There are limndreds of elasms in the Platean eoming whieh answer very well to this notion. Many of them are sunli to firightful deptlis and are fifty to a hundred miles in length. Some are exceedingly narrow, as the eanons of the forks of the Virgen, where the overhanging walls shut ont the sky. Some are intricately senlptured, and illmuinated with brilliant colors; other's are pictnresque by reason of their bold and striling senlptme. A few of then are $n$ ost solemn and impressive by reason of their profindity and the majesty of their walls. But as a mle the common eañons are neither grand nor even attraetive. Upon first acquaintanee thry are eurions and awaen interest as a new sensation, but they soon grow tiresome for want of diversity, and become at last mere bores. The inpressions they produee are very transient, becanse of their great simplicity and the limited range of ideas they present. But there are some which are highly diversified, presenting many attractive features. 'These seldom gr w stale or wearisome, and their presence is generally greeted with pleasnre.

It is perhaps in some respeets unfortmmate that the stupendons pathway of the Colorado River though the Kaibabs was ever ealled a cañon, for the nane identifies it with the baser conception. Bnt the name presents as wide a range of signifieation as the word honse. The log cabin of the raneher, the painted and vine-clad cottage of the mechanie, the home of the milliommaire, the places where parliaments assemble, and the grandest temples of worship, are all honses. Yet the cratrast between Saint Mare's and the rude dwelling of the frontiersman is not greater than that between the ebasm of the Colorado and the trenches in the rocks which answer to the ordinary coneeption of a cunon. And as a great eathedral is an immense development of the rudimentary idea involved in the four walls and roof of a eabin, so is the chasm an expansion of the sinple type of drainage channels peenliar to the Platean country. To the eoneeption of its vast proportions must be added some notion of its intricate plan, the nobility of its arehiteeture, its enlossal buttes, its wealth of onnamentation, the splendor of its eolors, and its wonderful atmospluere. All of these attributes eombine with infinite complexity to produce a whole whieh at first bewilders and at length overpowers.

From the end of Point Sublime, the distance aeross the clasm to the nearest point in the smmmit of the op posite wall, is about 7 miles. This, however does not fairly express the width of the ehasm, for both walls are reeessed by wide amplhitheaters, set ting far back into the platform of the eomntry and the promontories are eomparatively narrow strips between them. A more correct statement of the general width would be from 11 to 12 miles 'This must dispose at once of the idea that the chasm is a narrow gorge of immense depth and simple form. It is somewhat mnfortmmate that there is a previlent idea that in some way an 


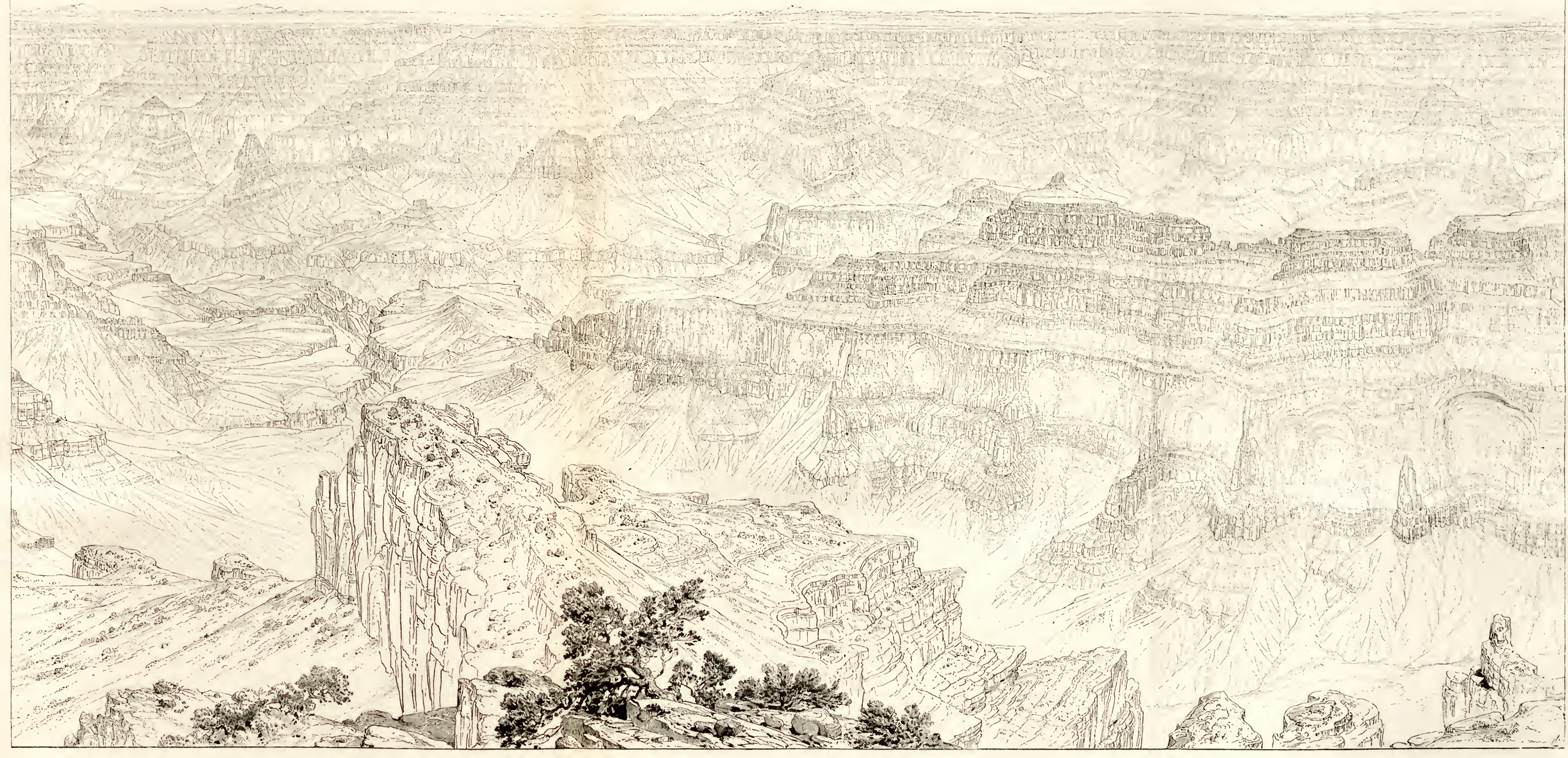

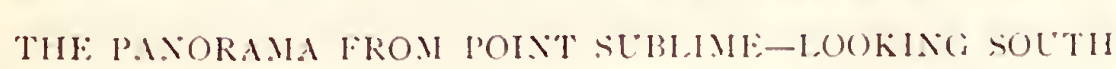


essential part of the grandeur of the Grand Cañon is the narrowness of its defiles. Much color has been given to this notion by the first illustrations of the eañon from the pencil of Egloffistein in the celebrated report of Lientenant Ives. Never was a great subject more artistically mis. represented or more chamingly belittled. Nowhere in the Kaibab seetion is any such extreme narrowness observable, and even in the Uin. karet section the will of the great inner gorge is a little greater than the depth. In truth a little reflection will show that such a character wonld be inconsistent with the highest and strongest effects. For it is obvions that some notable width is necessary to enable the eye to see the full extent of the walls. In a chasm one mile deep, and only a thonsand feet wide, this would be quite impossible. If we compare the Marble Cañon or the gorge at the Toroweap with wider sections it will at once be seen that the wider ones are much stronger. If we compare one of the longer alcoves having a willth of 3 or 4 miles with the view across the main chasm the advantage will be very decidedly with the latter. It is evident that for the display of wall smitace of given dimensions a certain amonut of distance is necessary. We may be too near or too far for the right appreciation of its magnitude and proportions. The distance must bear some ratio to the magnitude. But at what precise limit this distance must in the present case be fixed is not easy to determine. It can lardly be doubted that if the cañon were materially narrower it would suffer a loss of grandeur and effect.

The length of cañon revealed clearly and in detail at Point Sublime is abont 25 miles in each direetion. 'Towarls the northwest the vista terminates behind the projecting mass of Powell's Platean. But again to the westward may be seen the crests of the upper walls reaching through the Kanab and Uinkaret Plateans, and finally disappearing iu the haze abont 75 miles away.

The space under immediate view from our stand-point, 50 miles long and 10 to 12 wide, is thronged with a great multitude of objects so vast in size, so bold and majestic in form, so infinite in their details, that as the trutl gradually reveals itself to the perceptions it arouses the strongest emotions. Unqnestionably the orerruling feature is the colossal wall on the opposite side of the gulf. Can mortal fancy create a picture of at mural front a mile in height, 7 to 10 miles distant, and receding into space indefinitely in either direction? As the mind strives to realize its proportions its spirit is broken and its imagrination completely crushed. If the wall were simple in its character, if it were only blank and sheer, some rest might be found in contenplating it; but it is full of diversity and eloquent with grand suggestions. It is deeply recessed by alcoves and amphitheaters receding far into the platean beyond, and usually disclosing only the portals by which they open into the main chasm. Between them the promontories jut ont, ending in magnificent gables with sharp mitered angles. Thus the wall rambles in and out, turning numberless corners. Many of the angles are acute and descend as sharp 
spurs like the forward edge of a plowshare. Only those alcoves which are directly opposite to $\mathrm{ns}$ can be seen in their full length and deptl. Yet so excessive, nay so prodigious, is the effect of foreshortening, that it is impossible to realize their full extensions. We have already noted this effect in the Vermilion Cliffs, but here it is much more exaggerated. At many points the profile of the fiçade is thrown into view by the change of trend, and its complex character is fully revealed. Lilie that of the Vermilion Cliffs, it is a series of many ledges and slopes, like a molded plintli, in which every stratum is disclosed as a line or a course of nusonry. The Red Wall limestone is the most conspicnons nember, presenting its vertical face eight hundred to a thonsand feet ligh, and everywhere unbroken. The thinner beds more often appear in the slopes as a succession of ledges projecting through the scanty talus which never conceals them.

Numerons detached masses are also seen flanling the ends of the long promontories. These buttes are of gigantic proportions, and yet so overwhelming is the effect of the wall against which they are projected that they seem insignificant in mass, and the observer is often deluded by them, failing to perceive that they are really detached from the wall and perhaps separated from it by an interval of a mile or two.

At the foot of this palisade is a platform through which meanders the imer gorge in whose dark and somber depths flows the river. Only in one place can the water surface be seen. In its windings the abyss, which holds it extends for a short distance towards us and the hine of vision enters the gorge lengthwise. Above and below this short reach the gorge swings its course in other directions and reveals only a dark, narrow opening, while its nearer wall hides its depths. 'This inner chasm is 1,000 to 1,200 feet deep. Its upper 200 feet is a vertical ledge of sandstone of a dark rich brownish color. Beneath it lies the granite of a dark irn-gray shade, verging towards black, and lending a gloony aspect to the lowest deeps. Perhaps a half mile of the river is disclosed. A pale, dirty red, without glimmer or sheen, a motionless surface, a small featureless spot, inclosed in the dark shade of the granite, is all of it that is here visible. Yet we know it is a large river, a hundred and fifty yards wide, with a headlong torrent foaming and.plunging over rocky rapids.

A little, and only a little, less impressive than the great wall across the chasm are the buttes mpon this side. And such bnttes! All others in the West, saring only the peerless Temples of the Virgen, are mere trifles in comparison with those of the Grand Cañon. In nobility of form, beauty of decoration, and splendor of color, the 'Temples of the Virgen must, on the whole, be awarded the palm; but those of the Grand Cañon, while barely inferior to them in those respects, surpass them in magnitude and fully equal them in majesty. Bnt while the Valley of the Virgen presents a few of these superlative ereations, the Grand Cañon presents them by dozens. In this relation the comparison would be analogous 


$$
\operatorname{sen} x=\text { है }
$$


to one between a fine cathedral town and a metropolis like London or P'aris. In truth, there is only a rery linited ground of comparison between the two localities, for in style and eflects their respective structures difier as decidedly as the works of any two well developed and strongly contrasted styles of human arehitecture.

Whatsoever is forcible, eharacteristic, and pieturesque in the rockforms of the l'latem conntry is concentrated and intensified to the ntter. most in the buttes. Wherever we find them, whether fringing the long escarpments of terraces or planted upon broad mesas, whether in cañons or mpon expansive plains, they are always bold and striking in ontline and ornate in anchiteetnre. Upon their flanks and entablatures the decoration peculian to the formation out of which they have been carred is most strongly portrayed and the profiles are most sharply ent. 'They command the attention with special force and quicken the inagination

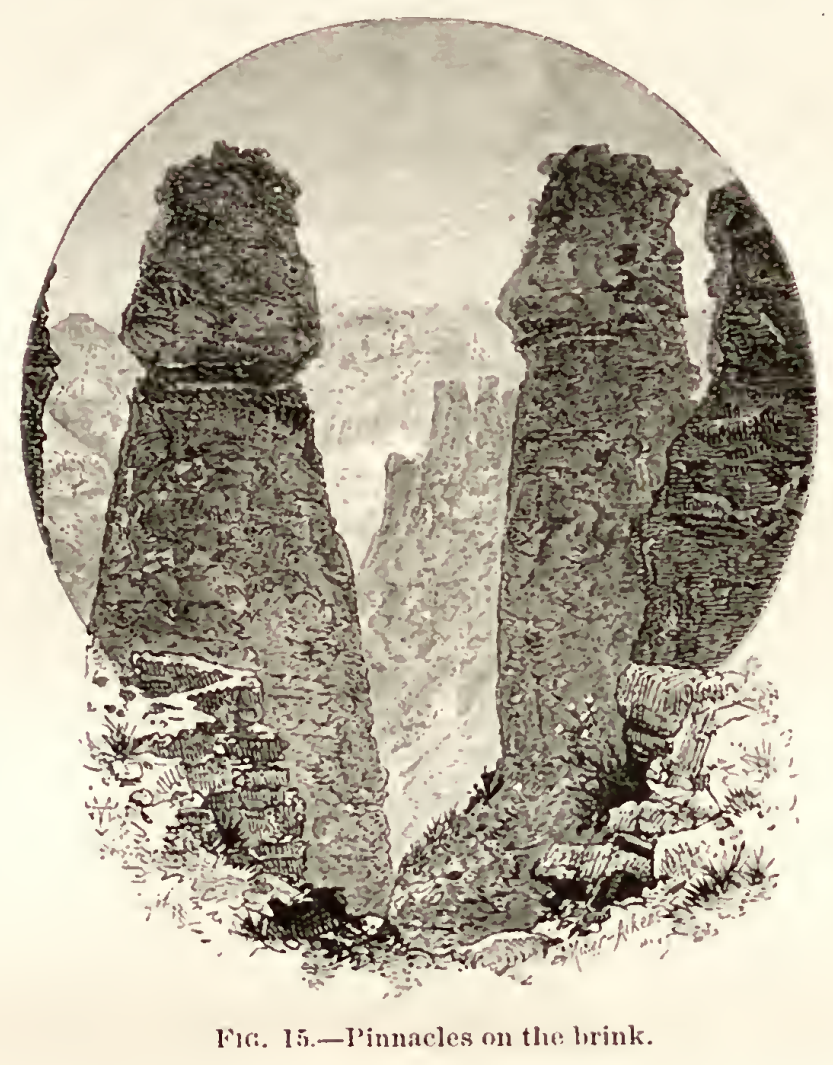

with a singular power. The secret of their inpressiveness is donbtless obseure. Why one form shonld be beantiful and another unattrative; why one shonld be powerful, animated, and suggestive, while another is meaningless, are questions for the psychologist rather than the geologist. Snfficient here is the fact. Yet there are some elements of impressiveness which are too patent to escape recognition. In nearly all buttes there is a certain definiteness of forn which is peculiarly emphatic, and this is seen in their profiles. Their gromnd-plans are almost always indefinite and caprieions, but the profiles are rarely so. These are usually composed of lines which have an approxinate and sometimes 
a sensibly perfect geometrieal definition. They are nsnally few and simple in their ultimate analysis, thougl by combination thes give rise to mneh variety. The ledges are vertical, the summits are horizontal, and the taluses are seginents of hyperbolas of long enrvature and eoneave npwards. These lines greatly preponderate in all cases, and thougl others sometimes intrude they seldom blemish greatly the effects produeed by the normal ones. All this is in striking eontrast with the evervarying, indefinite profiles displayed in monntains and hills or on the slopes of valleys. 'The profiles generated by the eombinations of these geometrie lines persist along an indefinite extent of front. Sneh variations as oecur arise not from changes in the nature of the lines, bnt in the modes of eombination and proportions. These are never great in any front of moderate extent, but are just sufficient to reliere it from a ecrtain monotony which wonld otherwise preval. The same trpe and general form is persistent. Like the key-note of a song, the mind earries it in its conscionsness whererer the harmony wanders.

The horizontal lines or courses are equally strong. These are the edges of the strata, and the deeply eroded seams where the superposed beds toueh eael other. Here the miformity as we pass from place to place is eonspienons. The Carboniferons strata are quite the same in every section, showing no pereeptible variation in thickness throngh great distances and only a slight dip.

It is readily apparent, therefore, that the effect of these profiles and horizontal eourses so persistent in their eharacter is liglily architectural. The relation is more than a mere analogy or suggestion; it is a rivid resemblance. Its failure or discordance is only in the ground plan, though it is not uncommon to find a resemblance, eren in this respect, among the Permian buttes. Among the buttes of the Grand Cañon there are few striking instances of definitenessin gronnd plan. The finest Lutte of the chasm is sitnated near the upper end of the Kaibab division; but it is not visible from Point Sublime. It is more than 5,000 feet high, and has a surprising resemblanee to an Oriental pagoda. We nained it Vishnn's Temple.

On either side of the promontory on whieh we stand is a side gorge simking nearly 4,000 feet helow us. The two unite in front of the point, and, ever deepening, their trunk opens in to the lowest abyss in the granite at the river. Across either brauch is a long rambling mass, one on the right of us the other on the left. We named them the Cloister's. They are excellent types of a whole class of buttes which stand in close proximity to each other upon the north side of the chasm thronghout the entire extent of the Kaibab division. A far better coneeption of their fol'us and featnres ean be gained by an examination of Mr. Holnes's panoranic picture than by reading a whole volume of rerbal description. The whole prospect, indeed, is filled with a great throng of similar objects, whicl, as much by their multitude as by their colossal size, eonfuse the senses; but these, on areconnt of their proxinity, may be most 


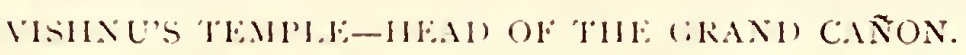


satisfactorily studied. The infinity of sharply defined detail is amazing. The eye is instantly caught and the attention firmly held by its systematie eharacter. The parallelism of the lines of bedding is most foreibly displayed in all the windings of the faeades, and these lines are erossed by the vertieal scorings of numberless water-ways. Here, too, are distinetly seen those details which constitute the peeuliaz style of deeoration prevailing throughout all the buttes and amphitheaters of the Kaibab. The conrse of the walls is never for a monent straiglit, but extends as a series of eusps and re-entrant curves. Elsewhere the reverse is more frequently seen; the projections of the wall are rounded and are convex towards the front, while the re entrant portions are cusp. like recesses. 'This latter style of deeoration is eommon in the Permian buttes and is not rare in the Jurassie. It produces the effect of a thickly set row of pilasters. In the Grand Cañon the reversal of this mode produees the effect of panels and niehes. In the western Cloister may be seen a suecession of these niehes, and though they are mere details among myriads, they are really vast in dimensions. Those seen in the Red Wall limestone are over 700 feet high, aud are overhung by arched lintels with spandrels.

As we contemplate these objeets we find it quite impossible to realize their magnitude. Not only are we deceived, but we are conseious that we are deceived, and yet we camnot eonquer the deception. We eamot long study our surroundings without beeoming aware of an enormous disparity in the effects produced upon the senses by objects which are immediate and equivalent ones which are more remote. The depth of the gulf whieh separates us from the Cloisters camot be realized. We crane over the brink, and about 700 feet below is a talus, which ends at the summit of the eross-bedded sandstone. We rnay see the bottom of the gorge, which is about 3,800 feet beneath us, and yet the talus seems at least half way down. Looling aleross the side gorge the cross-bedded sandstone is seen as a mere band at the sumnit of the Cloister, forming but a very small portion of its vertical extent, and whatever the reason may eonelude, it is useless to attempt to persuade the imagination that the two edges of the sandstone lie in the same horizontal plane. The eastern Cloister is nearer than the western, its distanee being about a mile and a half. It seems ineredible that it ean be so mueh as one-third that distance. Its altitude is from 3,500 to 4,000 feet, but any attempt to estimate the altitude by means of visual impressions is felt at onee to be hopeless. There is no stadium. Dimensions mean nothing to the senses, and all that we are eonscious of in this respeet is a troubled sense of inmensity.

Beyond the eastern Cloister, five or six miles distant, rises a gigantie mass which we named Shira's Temple. It is the grandest of all the buttes, and the most majestie in aspeet, though not the most ornate. Its mass is as great as the mountainous part of Mount Washington. That summit looks down 6,000 feet into the dark depths of the iuner 
abyss, orel a succession of ledges as impracticable as the face of Bunker Hill Monument. All around it are side gorges smlk to a depth nearly as profonnd as that of the main chamnel. It stands in the midst of a great throng of cloister-like buttes, with the same noble profiles and strong lineaments as those immediately before us, with a plexus of aw ful chasms between them. In such a stupendons scene of wreck it seemed as if the fabled "Destroyer" might find an abode not wholly nncongenial.

In ail the vast space beneath and around us there is rery little upon which the mind can linger restfully. It is completely filled with objects of gigantic size and annaing form, and as the unind wanders over them it is hopelessly bewildered and lost. It is useless to select special points of contemplation. The instant the attention lays hold of them it is drawn to something else, and if it seeks to recur to them it camot find them. Everything is superlative, transcending the power of the intelligence to comprehend it. There is no central point or object around which the other elements are grouped and to which they are tributary. The grandest objects are merged in a congregation of other's equally grand. Hundreds of these mighty structures, miles in length, and thomsands of feet in height, rear their majestic heads ont of the abyss, displaying their richly-molded plinths and friezes, thrusting ont their gables, wing-walls, buttresses, and pilasters, and recesserl with alcores and panels. If any one of these stupendous creations had been planted upon the plains of Central Enrope it would lave influenced modern art as profonndly as Fusiyama has influenced the decorative art of Japan. Tet here they are all swallowed up in the confusion of multitude. It is not alone the magnitude of the individual objects that makes this spectacle so portentons, but it is still more the extravagant profusion with which they are ar rayed along the whole visible extent of the broad chasm.

The color effects are rich and wonderful. 'They are due to the inherent color's of the rocks, modified by the atmosphere. Like any other great series of strata in the Plateau Province, the Carboniferous has its own range of characteristic colors, which might serve to distinguish it even if we had no other eriterion. The summit strata are pale gray, with a, faint yellow ish cast. Beneath them the cross-bedded sandstone appear's showing a mottled surfuce of pale pinkish hue. Underneath this member are nearly 1,000 feet of the lower Anbrey sandstones, displaying an intensely brilliant red, which is somewhat maslied by the talus shot down from the grey, cherty limestones at the summit. Beneath the lower Aubrey is the face of the Red Wall limestone, from 2,000 to 3,000 feet high. It has a strong red color, but a very peculial one. Most of the red strata of the west have the brownish or vermilion tones, but these are rather purplish-red, as if the pigment had been treated to a dash of bhe. It is not quite certain that this nay not arise in part from the intervention of the blue haze, and probably it is rendered more conspicuous by this cause; but, on the whole, the purplish cast seems to be inherent. This is the dominant color-mass of the canon, for the ex- 
panse of rock surfaee displayed is more than half in the Red Wall groul. It is less brilliant than the fiery red of the Aubrey sandstones, but is still quite strong and rieh. Beneath are the deep browns of the lower Carboniferous. 'The dark iron-blaek of the houblendic sehists revealed in the lower gorge makes but little impression upon the boundlessexpanse of briglit eolors abore.

The total effect of the entire eolor-mass is bright and glowing. There is nothing gloomy or dark in the picture exeept the opening of the immer gorge, which is too small a feature to influence materially the prevailing tone. Although the colors are bright when eontrasted witl normal landseapes, they are decidedly less intense than the flaming hues of the Trias or the dense cloying colors of the Permian; nor have they the refinement of those revealed in the Eocene. The intense luster which gleams from the rocks of the Platean country is by no means lost here but is merely subdued and liept under some restraint. It is toned lown and softened without being deprived of its character. Enough of it is left to produee eolor effects not far below those that are yielded by the Jura-Trias.

But thongh the inherent colors are less intense than some others, yet under the quickening influence of the atmosphere they produee effects to whieli all otlers are far inferior. And here language fails and description beeomes impossible. Not only are their qualities exceedingly subtle, but they have little counterpart in common experienee. If such are presented elsewhere they are presented so feebly and obseurely that only the most distriminating and closest observers of uature ever seize them, and they so imperfeetly that their ideas of them are vague and but half real. There are no conerete notions founded in experienee upon which a eonception of these color effeets and optieal delusions can be constructed and made intelligible. A perpetual glamour envelops the landscape. Thing are not what they seem, and the pereeptions cainot tell us what they are. It is not probable that these effeets are different in lind in the Grand Cañon from what they are in other portions of the Platean eomntry. But the differenee in degree is immense, and being greatly magnified and intensified many characteristics beeome palpable which elsewhere elude the elosest observation.

In truth, the tone and temper of the lindseape are eonstantly varying, and the changes in its aspeet are very great. It is never the sane, even from day to day, or even from hour to hour. In the early morning its mood and subjeetive influences are usually calmer and more full of repose than at other times, but as the sun rises higher the whole seene is so ehanged that we cannot recall our first impressions. Every pass. ing cloud, every change in the position of the sun reeasts the whole. At sunset the pageant eloses amid. splendors that seen more than earthly. 'The direction of the full sunlight, the massing of the shadows, the manner in which the side-lights are thrown in from the elonds determine these modulations, and the sensitiveness of the picture to the slightest variations in these conditions is very wonderful. 
The shadows thrown by the bold abrupt forms are exceedingly dark. It is almost impossible at the distance of a rery few miles to distinguish even broad details in these shadows. They are like remnants of midnight unconquered by the blaze of noonday. 'The want of half tones and gradations in the light and shade, which has already been noted in the Vermilion Cliffs, is apparent here, and is far more conspicuons. Onr thoughts in this comection may suggest to us a still more exireme case of a similar phenomenon presented by the half-illuminated moon when viewed througl a large telescope. The portions which cateh the surlight sline with great luster but the shadows of mountains and cliffs are black and impenetrable. But there is one feature in the cañon which is certainly extraordinary. It is the appearance of the atmosphere against the backgronnd of shadow. It has a metallic huster which must be seen to be appreciated. The great wall across the elrasm presents at noonday, under a clondless sky, a singularly weird and mearthly aspect. 'The color is for the nost part gone. In place of it comes this metallie glare of the haze. 'The southern wall is never so poorly lighted as at noon. Since its face consists of a series of promontories projecting towards the north, these projections catch the sunlight on their eastern sides in the forenoon, and upon their western sides in the afternoon; but near meridian the rays fall upon a few points only, and even upon these with very great obliquity. Thus at the hours of greatest general illumination the wall is most obseure and the abnormal effects are then presented most forcibly. They give rise to strange delusions. The rocks then look nearly black, or very dark grey and covered with feebly shining spots. The haze is strongly luminons, and so dense as to obscnre the details aheady enfeebled by shade as if a leaden or merenrial vapor intervened. The shadows antagonize the perspective, and ererything seems awry. The limes of stratification, dimly seen in one place and wholly effaced in another, are strangely belied and the strata are given apparent attitulles which are sometimes grotesque and sometimes impossible.

Those who are familiar with western scenery have, no dombt, been intpressed with the peculiar character of its haze, or atmosplere in the artistic sense of the word, and have noted its more prominent qualities. When the air is free from common smoke it has a pale bhe color which is quite mulike the nentral gray of the east. It is always appar. ently more dense when we look towards the sun than when we look away from it, and this difference in the two directions, respectively, is a maximm near smrise and sumset. 'This property is universal, but its pecnliarities in the Plateau Provinee become conspicnous when thestroug rich colors of the rocks are seen through it. The very air is then visible. We see it, palpably, as a temons fluid and the rocks beyond it do not appear to be colored blue as they do in other regions but reveal themselves clothed in colors of their own. The Grand Cañon is ever full of this haze. It fills it to the brin. Its apparent density, as elsewhere, is raried according to the direction in which it is viewed and the position of 
the sun; but it seems also to be denser and more eoneentrated than elsewhere. This is really a dehsion arising from the fact that the enormous magnitude of the chasm and of its eomponent masses dwarfs the distanees; we are really looking throngh iniles of atmosphere under the impression that they are only so many furlongs. 'This apparent eoncentration of haze, lowever, greatly intensifies all the beautifnl or mys. terious optical effects which are dependent upon the intervention of the atmosphere.

Whenever the brink of the chasm is reached the chances are that the sun is high and these abnormal effeets in full foree. The cañon is asleep. Or it is nnder a spell of enehantment which gives its bewildering mazes an aspect still more bewildering. Throughout the long summer forenoon the charm which binds it grows in poteney. At midday the clonds begin to gather, first in fleeey fleeks, then in cumuli and throw their shadows into the gulf. At once the scene changes. The slumber of the ehasm is disturbed. The temples and cloisters seem to raise thenselves lualf awake to greet the passing shadow. Their wilted, drooping, flattened faees expand into relief. The long promontories reael out from the distant wall as if to eatel a moment's refreshment from the shade. The colors begin to glow; the haze loses its opaque density and becomes more tennous. The shadows pass, and the chasin relapses into its dull sleep again. Thus through the midday hours it lies in fitful slnmber, overcome by the blinding glare and withering heat, yet responsive to every fhuctnation of light and shadow hike a delieate organism.

As the sun moves far into the west the seene again changes, slowly and imperceptibly at first, but afterwards more rapidly. In the hot snmmer afternoons the sky is fnll of eloud-play and the deep flushes with ready answers. The banks of snowy clonds pour a flood of light sidewise into the shadows and light up the gloom of the amphitheaters and aleoves, weakening the glow of the haze and rendering visible the details of the wall fices. At length as the sun draws near the horizon the great di:ma of the day begins.

'Thronghout the afternoon the prospect has been gradually growing elearer. 'Tle haze has relaxed its steely glare and has changed to a veil of transparent bhe. Slowly the myriads of details have eome ont and the walls are flecked witl lines of minute traeery, forming a diaper of light and shade. Stronger and sharper beeomes the relief of each projection. The promontories come forth from the opposite wall. The sinnous lines of stratification which once seemed meaningless, distorted, and even ehaotie, now range themselves into a true perspeetive of gracetul curves, threading the seallop edges of the strata. The eolossal buttes expand in every dimension. Their long narrow wings, which onee were folded together and flattened against eaeh other, open out, diselosing between them vast alcoves illumined with Rembrandt lights tinged with the pale refined blne of the ever-present haze. A thousand forms, hitherto unseen or obseure, start up within the abyss, and stand forth in 
strength anl animation. All things seem to grow in beanty, power, and dimensions. What was grand before has become majestic, the majestic becomes sublime, and, ever expanding and developing, the sublime passes beyond the reach of our faculties and becomes transcendent. The colors have come back. Inherently rich and strong, though not supcrlative under ordinary lights, they now begin to display an adventitions brilliancy. The western sky is all aflame. The scattered banks of cloud and wavy cirrhus have caught the waning splendor, and shine with orange and crimson. Broad slant beans of yellow light, shot through the glory-rifts, fall on turret and tower, on pinnacled erest, and winding ledge, suffusing them with a radiance less fulsome, but akin to that which flames in the western clouds. The summit band is brilliant yellow; the next below is pale rose. But the grand cxpanse within is a deep, luminous, resplendent red. The climax has now come. The blaze of suulight poured over an illimitable surface of glowing red is flung back into the gulf, and, commingling with the blue haze, turns it into a sea of purple of most imperial hue-so rich, so strong, so pure that it makes the heart ache and the throat tighten. However vast the magnitudes, however majestic the forms, or sumptuous the decoration, it is in these kingly colors that the highest glory of the Grand Cañon is rerealcd.

At length the sum sinks and the colors cease to burn. The abyss lapses back into repose. But its glory momts upward and diffuses itself in the sky above. Long streamers of rosy light, rayed ont from the west, cross the firmament and converge again in the east cnding in a pale rosy arch, which rises like a low aurora just above the castern horizon. Below it is the dead gray shadow of the world. Higher and higher climbs the arch followed by the darkening pall of gray, and as it ascends it fades and disippears, leaving no color except the after-glow of the western clouds, and the lusterless red of the chasm bclow. Within the abyss the darkness gathers. Gradually the shades deepen and ascend, hiding the opposite wall and enveloping the great temples. For a few moments the summits of these majestic piles seem to float upon a sea of blackness, then vanish in the darkness, and, wrapped in the impcnetrable mantle of the night, they await the glory of the coming dawn. 


\section{CHAPTER VIII.}

\section{THE EXCATATION OF' 'NHE CHASM.}

The excaration of the Grand Cañon and the sculpture of its walls and buttes are the results of two processes acting in concert-corrasion and weathering. In discussing them it is necessary to take into the account the peculiar conditions under which they have operated; conditions which have no parallel in any other part of the world.

In common parlance it is customary to say, for brevity's sake, that the rivers have cut their eañons; but the expression states only a part of the truth. 'The river has in reality cut only a narrow trench no wider than the river's water surface. It has been the vehicle which has carried away to another part of the workl the materials which have been torn from the strata by corrasion and weathering. Opening laterally into the main chasm are many amphitheaters excavated back into the platform of the comntry. At the bottom of each of them is a stream-bed over which in some cases a perenni the flows are spasmodic. Like the trmk river these streams have corraded their chamels to deptlis varying somewhat among themselves, but generally a little less than the deptli of the ecntral chasm. 'Ihese tributaries often fork, and the forks are in the foregoing respects quite homologous to the main amphitheaters. Down the faces of the walls and down the steep slopes of the taluses rum thousands of rain gullies. When the rain comes freely it gathers into rills which cascade down the wall clefts and rush headlong through the troughs in the talus carrying an abundance of sand and grit. These waters scour out their little channels in much the same way as their mited waters cut down their beds in the amphitheaters of the second and first orders, and in the main chasm itself. But the work of flowing water, whether in the main channel or in an amphitheater, or in a gully or cranny of the cliff, is limited to two functions. 'The first is the cutting of a channel no wider than the surface of the stream; the second is the transportation of the débris. Corrasion alone then could never have made the Grand Cañon what it is. Another process, acting conjointly with corrasion and dependent upon it, has effected by far the greater part of the excavation. 'This other process is weathering. In order to comprehend their combined action it is necessary to study their action in detail, and to study also the special conditions under which they have operated here. We shall find the subject a very complicated one. 


\section{CORRASION.}

Mr. G. K. Gilbert has embodied in his admirable monograph on the Henry Mountains, a chapter on Land Sculpture, which sets forth in most logical and condensed forn the mechanical principles which enter into the problems of erosion. In his analysis may be found a discussion of the conditions muler which the scnlpturing forces and processes achieve such peculiar results as we observe in the Plateau comtry.

'The perusal of thatehapter will give to the geologist's comprehension of the subject a most delightful definiteness and precision, and the reader, however learned he may be, will take great satisfaction in finding a subject so complex made so intelligible. The prineiples laid down by Mr. Gilbert will be adopted here and applied. For that purpose I quote from the chapter referred to such statements as are of immediate service.

The mechanieal wear of streams is performed by the aid of hard mineral fragments carried along by the current. The effective foree is that of the enrrent; the tools are mud, sand, and bowlders. The most inportant of them is sand; it is eliefly by tho impact and friction of grains of sand that the rocky beds of streams are disintegrated.

Where a stream las all the loal of a given degree of comminution which it is eapable of earrying, the entiro energy of the desecnling water and load is consumed in the translation of the water and load, and there is none applied to corrasion. If it has an exeess of load, its velocity is thereby diminished so as to lessen its competence and a portion is dropped. If it has less than a full load, it is in condition to receive more, and it corrades its bottom. A fully-loaded stream is on the verge between corrasion and depesition. * * * The work of transpertation may thus monopolizo a stream to the exelusion of corrasion, or tho two works may be carried forward at the same time.

'Tlie rapidity of meehanieal corrasion depends on the harduess, size, and number of the transient fracrments, on the liarduess of the roek-bed, and on the velocity of the strean. * * * The element of volocity is of doublo importance, since it determines not only the speed, but, to a great extent, the sizo of the pestles which grind the rocks. The co-effieients upon which it [reloeity] in turn depends, namely, declivity and quantity of water, liave the same importanee in eorrasion that they have in transportation.

Let us suppose that a stream endowed with a eonstant rolnumo of water is at somo point contiuuously supplied with as great a load as it is capablo of earrying For so great a distanee as its velocity remains the same, it will neitler corrale nor deposit, but will leave the declivity of its bed unchanged. But if in its progress it reaches a place where a less declivity of bed gives a diminished relocity, its eapacity for transportation will beeome less than the load, and a part of the load will be deposited. Or if in its progress it reaclics a place whero a greater deelivity of bed gives an inereased velocity, the eapacity for transportation will become greater than the load and there will be eorrasion of the bed. In this way a stream which has a snpply of débris cqual to its eapacity tends to build up the gentler slopes of its bed and to cut away the steeper. It tends to establish a singlo miform grade.

Let ns now suppose that the stream, after having obliterated all of tho inequalities of the grade of its bed, loses nearly the whole of its load. Its relocity is at once aecelerated and vertical corrasion begins througli its whole length. Sinee tho stream has the samo declivity, and consequently the samo velocity, at all points, its eapacity for eorrasion is everywhere the same. Its rate of corrasion, lowever, will depend upon the character of its bed. Where the rock is harl, corrasion will bo less rapid than where 


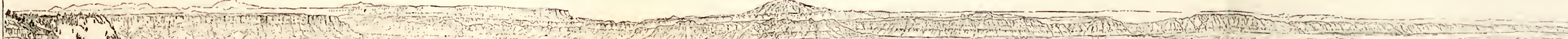

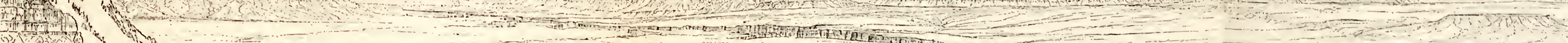
. (1)

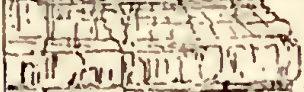

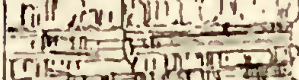

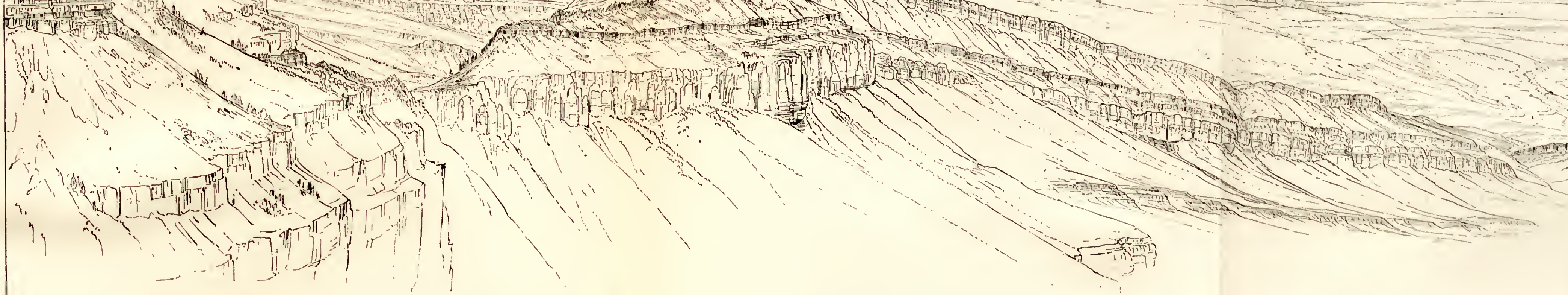

A

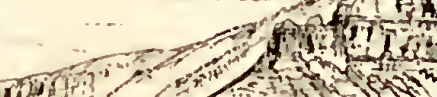

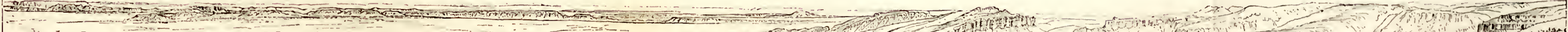

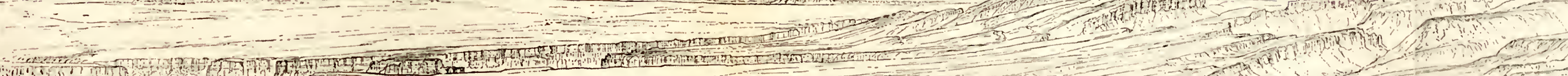

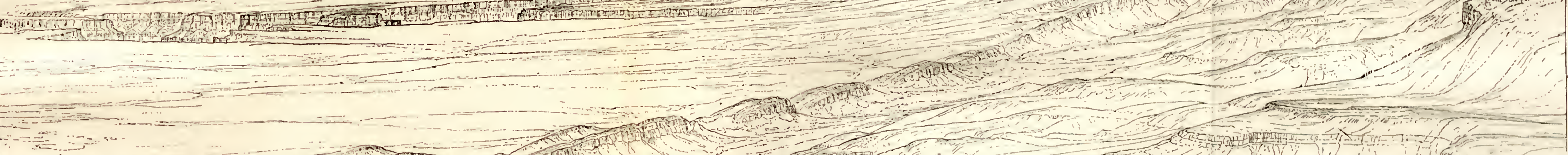

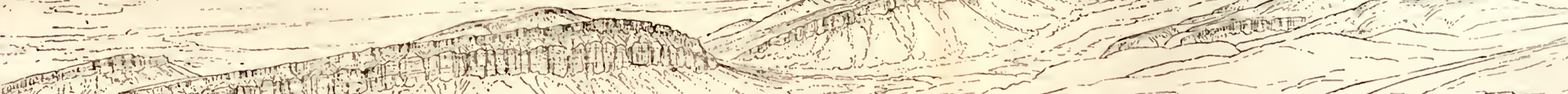

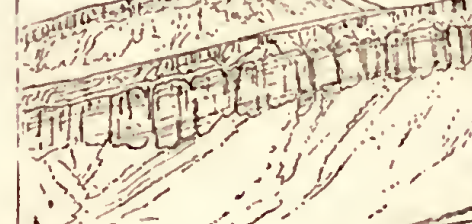
(1) 2 (1)

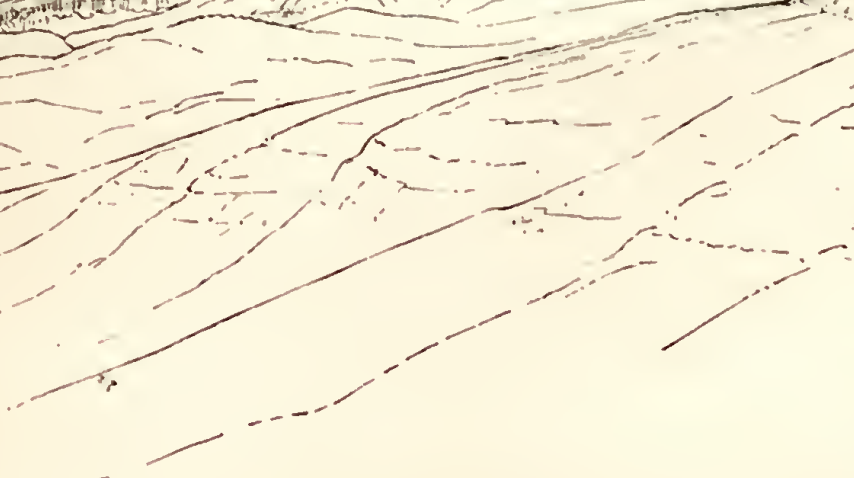


it is soft, and there will resnlt inequalitics of grade. But so soou as there is incquality of grade there is inequality of velocity and uncquality of capacity for corrasion; and where hard rocks have prodneed declivitics, thero the capacity for corrasion will be increased. 'The differentiation will proceed until the eapacity for corrasion is everywhere proportional to the resistance to be encountered; that is, mntil there is equilibrinm of action.

In gencral wo may say that a strcam tends to equalize its work in all parts of its conrse. Its power inheres in its fall, and each foot of fall has the same power. When its work is to corrade and the resistance uncqual, it eoncentrates its encrgy where the resistance is great by crowding many fect of descent in to a small space, and difinses it whero the resistance is small by using but a small fall in a long distance. When its work is to transport, the resistance is constant and the fall is cvenly distributed by at uniform gradc. When its work includes both transportation and corrasion, as in the nsual case, its grades are somewhat uncqual and the inequality is greatest when the load is lcast.

The foregoing analysis is applicable to the Colorado. It is, in respect to corrasion, an exceptional river. Nearly all the large rivers of the world along their lower and mildle courses have either reached, or closely approximated to, that condition of equilibrium which Mr. Gilbert spealis of, in which the transporting power is nemly adjusted without excess to the load to be carried. They have little or no surplus energy to spare for corrasion, and therefore neither corrade nor deposit. But the Colorado is corrading rapidly, and has doubtless done so with little interruption througlout the entire period of its existence. The cause may be discerned in one important fact alrealy brought out. The region it tra. ver'ses has been throughout Tertiary time steadily rising, and the total elevation has been enormous. This progressive eleration has antagonized the tendency of the river to reach that adjustment of its energy to the work of transportation alone, and las kept alive its corrasive power. There have been probably some limited periods in the history of the river in which, for the time being, it had sunk its channel until it reached a "base-level" -a grade below which it could not corrade. But this state of affuirs was afterwards subverted by a further elevation which increased the dechivities of the channel, restoring the corrasive power. The last great upheaval, exceeding in amount 3,000 feet, was of comparatively recent occurrence, and the river has not yet reached the new equilibrium of action and the new adjustment of its energy to the work of simple transportation.

The reader who for the first time is brought to consider the enormous depth of the gash which the Colorado has cut would naturally turn to the rivers with which he is familiar to inquire whether they disclosed evidence of similar and commensurate action. He would rarely find any such evidence. It is only by examining the physical conditions of the Colorado and comparing them with other rivers in the light of such principles as Mr. Gilbert has laid down that the facts become intelligible. The first and most important factor to be considered is its declivity. The fall of the Colorado and its principal fork, the Green River, from Green River Station, on the Pacific Railway, to the end of the Grand Cañon, a 
distanee, as the river runs, of ahout 1,050 miles, is about 5,150 feet, or very nearly five feet to the mile. The fall through the Grand Cañon is on an average 7.56 feet to the mile. Taking the several divisions of the Grand Cañon, the declivity may thus be tabulated:

Declivity of the Colorado in the Grand Cañon.

\begin{tabular}{|c|c|c|c|}
\hline Subdivisions. & $\begin{array}{l}\text { Distance } \\
\text { in miles. }\end{array}$ & $\begin{array}{l}\text { Fall in } \\
\text { feot. }\end{array}$ & $\begin{array}{l}\text { Fall in } \\
\text { fertpor } \\
\text { milo. }\end{array}$ \\
\hline 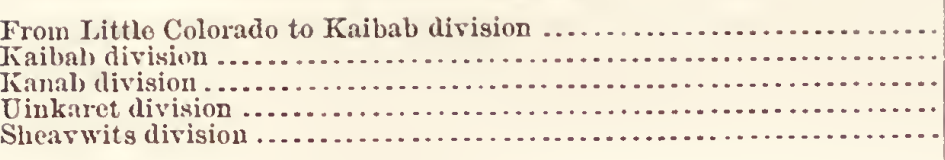 & $\begin{array}{l}9.6 \\
58 \\
47.6 \\
19.2 \\
84\end{array}$ & $\begin{array}{r}60 \\
700 \\
240 \\
100 \\
540\end{array}$ & $\begin{array}{r}\text { 6. } 25 \\
12.07 \\
5.01 \\
5.21 \\
6.43\end{array}$ \\
\hline Totals............. & 218.4 & 1,640 & 7.56 \\
\hline
\end{tabular}

The Marble Cañon, with a length of 65.2 miles, has a descent of 510 feet, or an average fall of 7.82 feet per mile. When compared with the declivities in the middle and lower conrses of other large rivers, that of the Colorado in the cañons is seen to be very exeessive. It falls about as many feet as the others fall in inches. The flow of other large rivers which are usnally considered swift is ealm and easy in conparison with the rush of the waters of the Colorado.

There is another faetor which would be fatal to corrasion in other rivers, but which in this one greatly augments its eorrasive power. Not only are few rivel's so swift, but fewer still are so continuously turbid and so heavily charged with sediment. Rarely is the river clear, even in the droughts of midsummer. Immense quantities of sand and elay are swept along at all parts of the year. Ordinary livers, and even most of the exceptional ones, wonld be gorged with such quantities of sand, and instead of corrading would have their energies fully taxed in earrying the load which the Colorado bears easily. 'This sand is the tool which it employs for its work, and it uses it with great effeet. Though the river is heavily loaded, it is still underloaded, and has great power to colrade.*

'To show how effieient the eorrasive action may become under extremely favorable circmunstances, we may cite the case of some of the great hydranlie mines in Calitornia. In these mines powerful streams of water are discharged against the gravel banks, and the spent water is gathered into a brook which findsits way over the "bed-rock" into a tumnel, and finally escapes into some deep uatural gorge below the level of the workings. As the water flows away it carries with it all the débris washed from the banks, whether eoarse or fine. In the wellknown Bloomfield mine I saw a gash in the solid basaltie bed-rock 12 feet in depth, which I was assured had been cut by the eseaping water and gravel in a period of about sixteen months. The aetual ruuning

- The details of corrasion in the cañon will bo much moro fully discussed in the monograph on the Grand Cañon District. 
time of the water, howerer, had been equivalent to abont 145 days of twenty-four homrs each. This case is indeed a most extreme one, and no natnral river can show any sueh rapid eorrasion of any considerable length of its bed. It is not eited to support an inferenee of plrenomenal rapidity in the corrasion of the Grand Cañon, but rather to illnstrate the efficiency of corrasive action when all the attendant conditions are extremely fitvorable and no comntervaling condition is present. Bnt althongh the Colorado is far from being such an extreme case as the one just mentioned, it is still a very strong one. Yet there are some stretches in the rirer where the corrasion must be proceeding at a very rapid rate-at a rate not very many times slower than in the Bloomfieh mine. These portions are in the hardest rocks, and they ilhstrate well the law which Mr. Gilbert has so elearly ennneiated (p. 157, line 44).

The conrse of the Colorado in the Grand Cañon is a snceession of hendlong rapids or cataraets and of smooth but swiftly-flowing reaches. In the Kaibab division the rapids are very numerous, very long, and very frequent, while the still reaches are short. In the Kanab division the rapids are tewer and less formidable, while the still reaches are longer. In the Shearwits, the condition is intermediate between those of the Kaibab and Kanab divisions. The rapids, howerer, are of two kinds. and are the results of two wholly independent canses. (1.) When the stream lies in the lind rocks, the declivity is much greater, and the rapid is then due to the greater slope of the bed. (2.) At the opening of every side.gorge, a pile of large bowlders and rnbble is pushed ont into the stream. Most of the side-gorges are dry through. out the greater part of the year. But when the rains do come, their effeets are prodigious.* In the vast amphitheaters the water is quickly shot down into the ehamnel and rushes with frightful velocity along the bed, whiel has a slope of 210 feet or more to the mile. Nothing which is loose and which lies in the way of it can resist its terrible rnsh. Bowlders of many tons' weight are swejt along like ehaff', and go thmnding down the side gorges into the main river. When the torrents reach the river the large fragments are dropped; for the maximmn slope of the main stream (reekoned throughout any stretch exeeeling four or five miles) never exceeds 25 feet to the mile; and the water, thongh great in rolume at flood-time, has muel less velocity than the torrents of the side chasms. The river has, however, abundant power to sweep along fragments of eonsiderable size, which are gromnd up as they move onward. 'The eoarse inaterial, the large bowlders and rnbble washed ont of a lateral chasin, form a dam where the river becomes a eataract. They are also strung out for considerable distances below the dam, and thus the tendeney is to build $n p$ and increase the grade of the river

* It is well to remember here the grand scale on which these lateral features of the chasm are laid out. The watersheds of these auphitleaters cover each from 10 to 50 square miles! And when a hoary rain eomes, whatever water is not soaked up by the rocks and soil is in the bottom of the amplitheater in less than ten minutes!! 
just beyoud the rapid. But this tendency is quickly checked and brought to a stop by the increased power of the eurrent duc to the increased slope. The body of fragments brought into the river laterally is vast in amount. But on the whole it is insufficient at the present epoch to prevent the river from corrading its channcl, though corrasion is greatly retarded by it. There are many stretches where there is an equilibrium between the tendency to cut deeper and the tendency to build up the bottom by the accumulation of debris; where the whole encrgy of the river is consumed in dissipating the fragments brought into it. But there are other portions where the river bed is in the bare rock of Palæozoic and Archæan strata, and wherever it is so corrasion is procceding rapidly.

\section{WEATHERING.}

The work of corrasion is limited to the cutting of narrow gashes in the strata, and the grinding up of the fragments brought into the river channcls. The widening of thesc cuts into the prescnt configuration of the chasm is the work of weathering. The common notion is that "solid rock" is but little affected by any natural agents such as water and air, and though it is acknowledged that water and carbonic acid exert a ccrtain nominal solvent and chemical action upon rock material, yet thcse are usually esteemed so feeble that even the enormous periods of time which the geologist invokes sccm quite insufficicnt to warrant us in ascribing to them any very important effects. Our observation upon the works of human construction which have been exposed for many ccnturies to the action of the elements confirms this notion. The structures of Egypt, Grecce, and Italy have bcen thus exposed for periods which are nearly or even exactly known. They bear evidence that this action is a real one, and that their final dissipation would, in the event of indefinite cxposure, be a mere question of time. But they also indicate that so far as their own materials are concerned the process is exceedingly slow. Their rate of dccay by solution, if applied as a factor to the recession of the walls of thic Grand Cañon, would givo a period of time so vast that the mind would promptly reject it because of its very enormity. But we shall find that the recession of those walls goes on, slowly indeed, but at a rate very much greater than would be infcrred from an inspection and comparison of the works of human antiquity.

It is at onee obvious that the building-stones are not a fair eriterion. They are selceted for their durability, and of all rocks they represent those which offer the greatest possible resistance to weathcring. Taking the common rocks only-those of frequent and world-wide occurrencethere is reason to believe that their rates of decay under equal conditions vary among themselves enormously. Leaving out of the account the unconsolidated or loosely consolidated strata, it cannot be doubted 


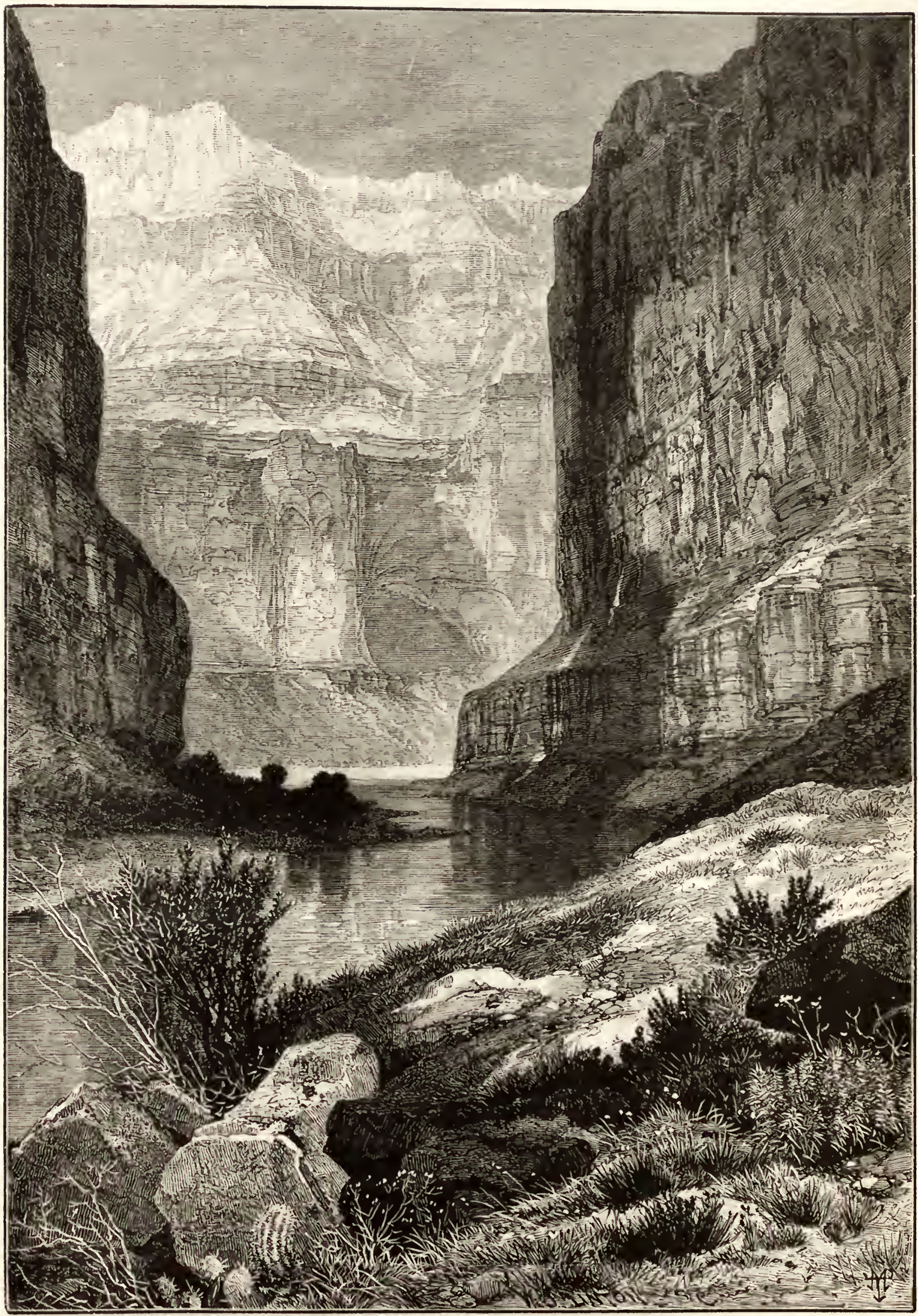

THI MAKBLE CAÑON 
that some indurated rocks decay fifty times faster than others, the conditions being identical as to climate and exposure. We have, it is true, no experimental or laboratory data upon which this assertion can be based, but it is, I am confident, quite defeusible, and will appear to be so when we examine the results of weathering in the rocks in place. For there is another consideration which is not apparent in the decay of buildiug-stones. The strata are disintegrated by a process which includes something far more efficient than mere solution or chemical decomposition.

At the base of every cliff in the Plateau country we find a large talus cousisting of fragments fallen from the rock faces above. The fragments vary in size from bowlders of many tous' weight down to the finest gravel, sand, and clay. Here is proof at once that the decay of cliffs goes on chiefly through the breaking off of fragments. It soon appears that the amount of material removed from the wall in solution is but a very trifling fraction of the quantity which has spalled off from the faco of the wall. As the large fragments fall off from the vertical front they are dashed to pieces below. In this fragmental condition they expose a much greater surface to weathering and are dissipated with correspondingly increased rapidity. And now we come to the key of the problem. 'The explanation of those persistent profiles of the Grand Cañon is found when we analyze the formation and decay of talus. It is one of the most charming studies in the whole range of physical geology.

In the Carboniferous strata of the Grand Cañon we have a nass of rocks widely varying in lithological characters, but which on the average are just about as obdurate to weathering as the average of rocks found in other regions. So far as can be seen or inferred, in this respect they differ not at all from the strata of other regions. Some of them weather easily, some are very obdurate. Perhaps the only qualification to this comparative statement is that there are no extremely perishable strata in the whole series. The softest beds are still firm and perfectly indurated. The degrees of obduracy, however, appear to vary greatly in the series.

The upper stratum in the cañon wall is a cherty limestone, which is harder* than the average, though not extreme in that respect. It forms usually a precipitous face, though it is frequently breached and broken down. It is out of this series that the rows of pinnacles in the crest of the cañon are carved.t Beneath it is another series of limestones of less than average harduess. They are sometimes a little clerty

\footnotetext{
* In speaking hero of relative hardness and softuess, I wish to be understood as meaning the resistanco which the rock opposes to destruction by direct reathering, and not hardness in the mineralogical sense, nor the resistaneo which the roeks might offer to the tools of the stone-entter.

$\uparrow$ The eherty limestones are full of silicious nodules. Thoy oceur in vast numbers and show a tendency to arrange themselves in bands parallel with the bedding. Tho inclosing matrix, though inainly ealcareous, has much disseminated silica in tho cherty form. In the reathering the nodules aro dissolvel out of tho matrix and fall down the cliffs.
} 
but far less so than the overlying beds. They break down always into a steep slope, corered with a talus partly of their own débris and partly of the cherty nodules weathered out from above. Beneath the limestones lies the cross-bedded sandstone, one of the most conspicuous members of the cañon. Or all the strata it is the hardest; in truth, is about as adamantine as any rock to be found in the world. It forms everywhere the vertical frieze of the upper wall and is rery seldom broken down into a slope. Underneath it comes the great series of Lower $\Delta$ ubrey sandstones, a thousand feet thick, made np of very many individual beds. They are similar in character, and all of them weather rapidly. We have, then, in the Upper and Lower Aubrey Groups, which form the outer chasm wall at the Toroweap (and which are almost exactly the same elsewhere throughout the Grand ('añon), four groups of strata which are alternately hard and soft (Fig. 16), (1) a hard clierty limestone, (2) a softer limestone, (3) an extremcly hard sandstone, (4) a great thickncss of much softer sandstones.

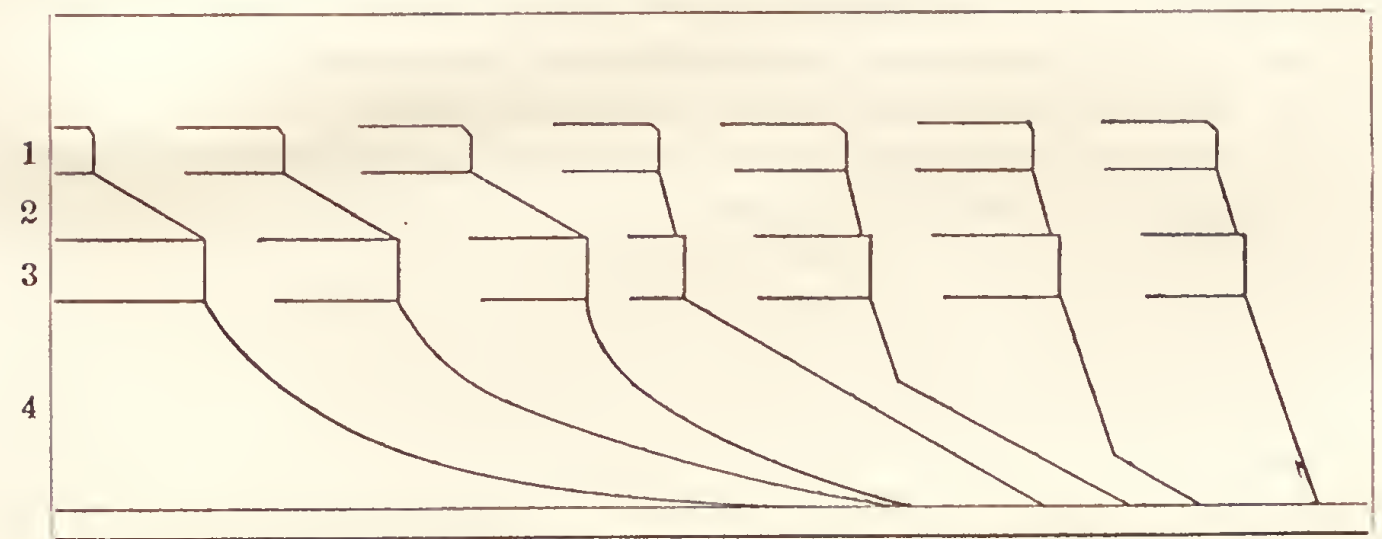

Fig. 16.-Derelopment of cliff profiles by recession in the npper wall of the chasm.

It has alrcady becn cxplained that the attack of erosion is made chicfly upon the scarp walls and steep slopes of a country and only feebly upon level surfaces. Imaginc, now, a cut made by a corrading stream into such a serics of strata as that which has just becn described. It will soon appear that it is quitc immaterial whether the cut be made very gradually or instantly,-by a miracle, as we may suppose. Weathering at once attacks the face of the wall. . The softer beds yielding much more rapidly, gradually undermine the harler ones above, and the latter cleave off by their joints and great fragments fall down. If we suppose the corraded cut to have been made instantly and the river to be flowing in it, the fragments would at first fall into the stream and be devoured by corrasion as fast as they fall. But after a time the widening of the eut so produced would leare a platform on the margin of the stream where the fragments would begin to form a talus. As the recession by waste goes on, the talus grows larger and larger, and gradually mounts up on the breast of the lower wall. Now the cffect of a talus is to protect the beds 11 pon whose edges it lies, and to retard their rate of decay by virtue 
of that protection. At first, then, the talus eanses the lowest beds to lag behind in the reeession. $\Lambda$ s it mounts up the wall, higher and ligher beds gain proteetion, and they, too, begin to lag behind, mutil at last the talus mounts up rery nearly to the base of the extremely hard, cross. bedded sandstone. Thus the entire lower series of soft strata beeomes eonverted into a slope eorered with talus, and at this stage all the beds above stand as a single rertical faee. But immediately a seeond eliff and talus begin to form above the hard sandstone; for sinee the lower soft beds are proteeted and their rate of recession reduced by the talus, the upper soft beds, being naked, must reeede at a more rapicl rate, until they, too, become a slope and receive the protection of a talus from the hard limestone at the summit.

It appears, then, that the recession of the hard beds is aecelerated by undermining, while the reeession of the soft beds is retarded by the proteetion of the talus. The result is the final establishment of a clefinite profile, which thereafter remains very nearly eonstant as the cliff eontinues to reeede. Thus the talus is the regulator of the cliff profile. There are many minor features which may be explained as satisfactorily, and one of them is the eurvature of the Lower Aubrey profile.

Throughout the greater part of the ehasm the slope of the Lower Aubrey is a very graeeful eurve, but in the Kaibab division it is nsually straight and descends at an inelination of about 30 degrees, the angle of repose, or very nearly so, for the débris whieh oceurs here. Taking first the Toroweap section, we remark that at the base of the main palisade is the broad esplanade or plain whieh forms the floor of the upper ehasm. It is from a mile to three miles in width. In a great talus the fragments are slowly and eontinually ereeping down by the aetion of rain and frost. The plain at the base aets as a elieck to the descent. Nowhere exeept, perhaps, at a notable distance away from the base or in the very lowest part of the stratigraphie series are the beds wholly buried in tilus. Considerable areas of roek surface projeet through the covering. The tendeney of the descent of talus under the eonditions here eonsidered is to give more protection to the lower beds than to the higher. The eheck given to the deseent of the talus by the level plain is felt more strongly at the base of the slope than higher up. Moreover, the finer débris is more readily washed down a slope of given dechivity than the coarse, and thus the debris at the base of the talus is finer than that above; and fine débris is a more efficient protection than coarse. In consequenee of this greater proteetion, the recession of the lower heds is less rapid than that of the higlier ones, and in genemal terms the protection of any given bed in the slope is inversely proportional to the square or some other eomplex function of its height above the base. The eurved profile at onee follows, and it is demonstrably of the hyperbolie elass.

In the Kaibab the ease is different. Here the mighty plinth of the Red Wall limestone euts off the foot of the Lower Aubrey slope, giving 
a free discharge to the fragments into the depth below. There is no check to the descent of the talus; the amount of protection given by it to all the beds of the Lower Aubrey is very nearly uniform, and the slope becomes straight. But whenever, as sometimes happens, the top of the Red Wall precipice stands at an unusual distance from the Lower Anbrey, the curvature of the profile of the latter appears, and its emphasis is proportional to the distance which separates the rertical planes of the Red Wall and of the cross-bedded sandstone.

Many details of repetitive or systematic sculpture are presented in the great chasm, and they may be explained as readily as the profiles. Only one otlier feature can be alluded to here, and the allusion will be brief. It concerns the plan or horizontal projections of the component features of the Kaibab division, the blocking out of the cloister buttes and the temples, and their reduction to their present forms. In a general way it is apparent that these have been originated by the profound corrasion of short lateral tributaries of the Colorado and the subsequent widening of the cuts into the present amphitheaters and alcoves; the buttes and temples being the residual masses between them. But the contours of the latter are striking aud peculiar in the extreme. They are explained by observing that wherever recession of the cliffs takes place it proceeds with great uniformity along the entire front. It starts along the line of a stream which is tortuous, but as it proceeds it carries back the cliff in a succession of curres, and in process of time minor inequalities are obliterated. Each larger bend of the stream gires rise to its own curve in the trend of the wall, and where successive curves intersect they form very sharp cusps. Everything here depends upon uniformity in the rate of the recession of all parts of the cliff. Where the outward spreading circles of erosion from two distinct alcoves or amphitheaters meet by recession in opposite directions, a butte is cnt off and a saddle or "col" is formed. The cusps between two intersecting circles are exceedingly sharp and well formed, and three circles generally give rise to a fine gable.

The peculiar cliff-forms of the Plateau country would hardly be possible in ans other, for no other presents those conditions which are necessary for them. These conditions may be summarized as follows: (1.) The great elevation of the region. (2.) The horizontality of the strata. (3.) A series of strata containing very massive beds which differ greatly among themselves in respect to hardness, but each member being very homogeneons in all its horizonial extent; in a word, heterogeneity in vertical range and homogeneity in horizontal range. An arid climate. The great elevation is essential to high reliefs in the topography. Only in a ligh country can the streams corrade deeply, and it is by corrasion of streams that the features are originated and blocked out. The effect of horizontality of the strata is self-evident. With regard to vertical leterogeneity, it is apparent that it is essential to give diversity to profiles. If the rocks were homogeneous in vertical 
